Historic, Archive Document

Do not assume content reflects current scientific knowledge, policies, or practices. 



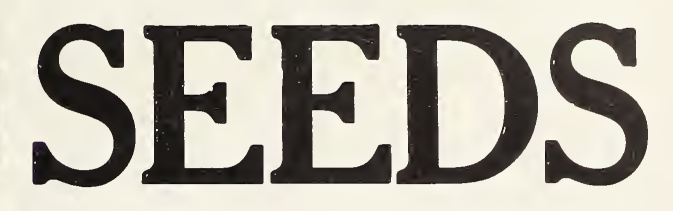

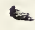

\section{for \\ FARM and \\ GARDEN}

Bulbs and Fertilizers

Garden Implements

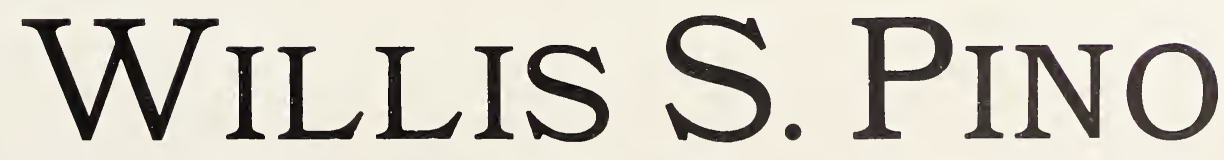

41 WASHINGTON STREET, CORNER EDDY

PROVIDENCE, R. I. 


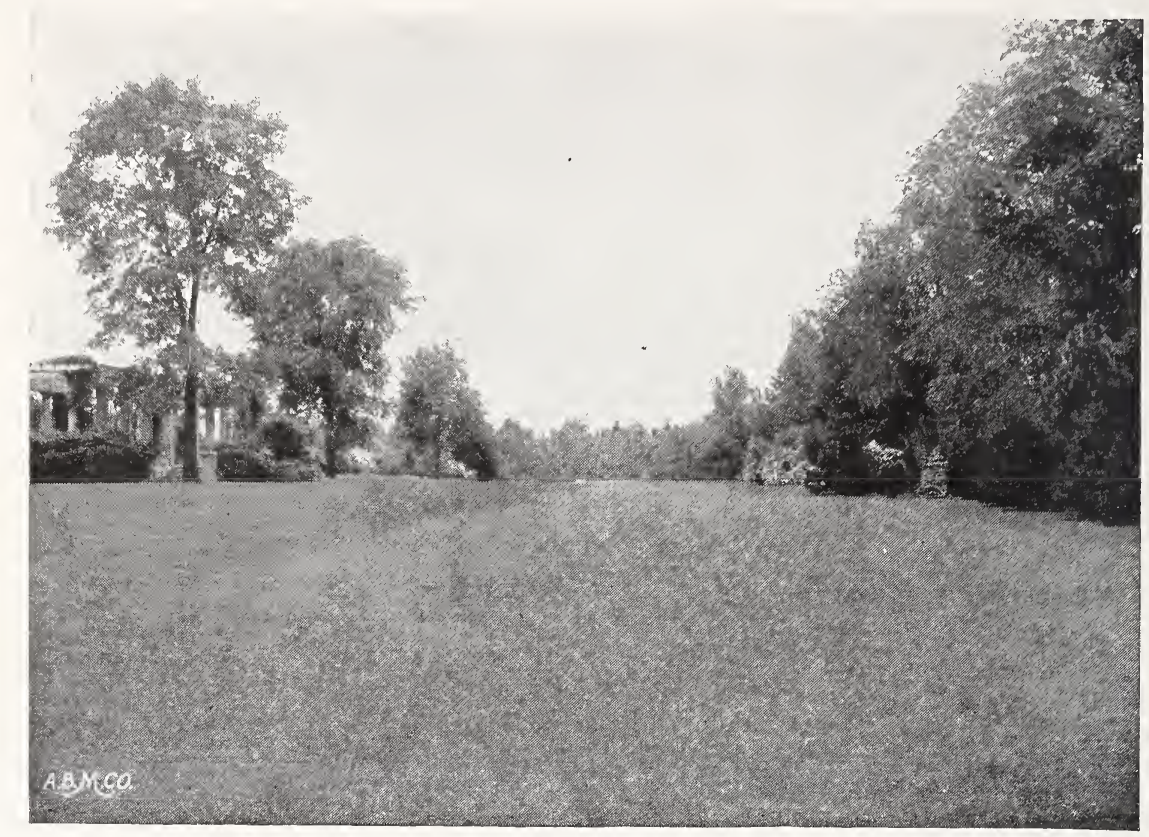

\title{
The Preparation and Care of a Lawn
}

A well cared for lawn adds more than any other one thing to the attractiveness of the home grounds, and not only this, but it increases the value of property by much more than the mere expense of securing the lawn. There are a few simple rules which, if followed consistently, will be certain to bring good results.

The ground must first be thoroughly prepared by draining, if necessary, and spade or plow to the depth of 6 to 12 inches, according to the nature of the soil, applying a liberal quantity of well decomposed manure, bone meal or purverized sheep manure, the latter we recommend as being lasting in effect, not liable to burn the grass and free from weeds.
Clean the ground thoroughly and rake perfectly smooth and level, as much of the success depends upon this part of the preparation. The seed should be sown on a calm day, that it may be applied evenly and at the rate of sixty-four pounds per acre, or one pound is sufficient for 600 square feet. After the seed is sown the ground should be rolled with a light roller or evenly tamped with the back of a spade. The plat should be mowed every ten days from May until September, using a sharp scythe in preference to a mower until a close turf is formed. Frequent mowing and rolling is necessary to maintain a close even turf. April and September are the best months for sowing lawn seed.

\section{Park Lawn Grass Mixture}

In our lawn mixture we use only the highest quality, extra clean seed, and free from weed seeds which abound in inferior grades. We use only the choicest low growing grasses, and a lawn produced from our seed will maintain a rich, dark velvety appearance and a permanent sod. One pound will sow 600 square feet. $1 / 2$ 1b., 20c: 1 1b.. 35c; 2 lbs., 60c; 100 1bs., \$25.00.

\section{Shady Nook Grass Mixture}

A special mixture of grasses adapted to growing under trees and in shady places, where it is quite difficult to produce a satisfactory growth. 1 quart, 30c; 1/2 pk., \$1.00; 1 peck, \$1.75.

\author{
For Lawn Dressing Use \\ Pulverized Sheep Manure
}




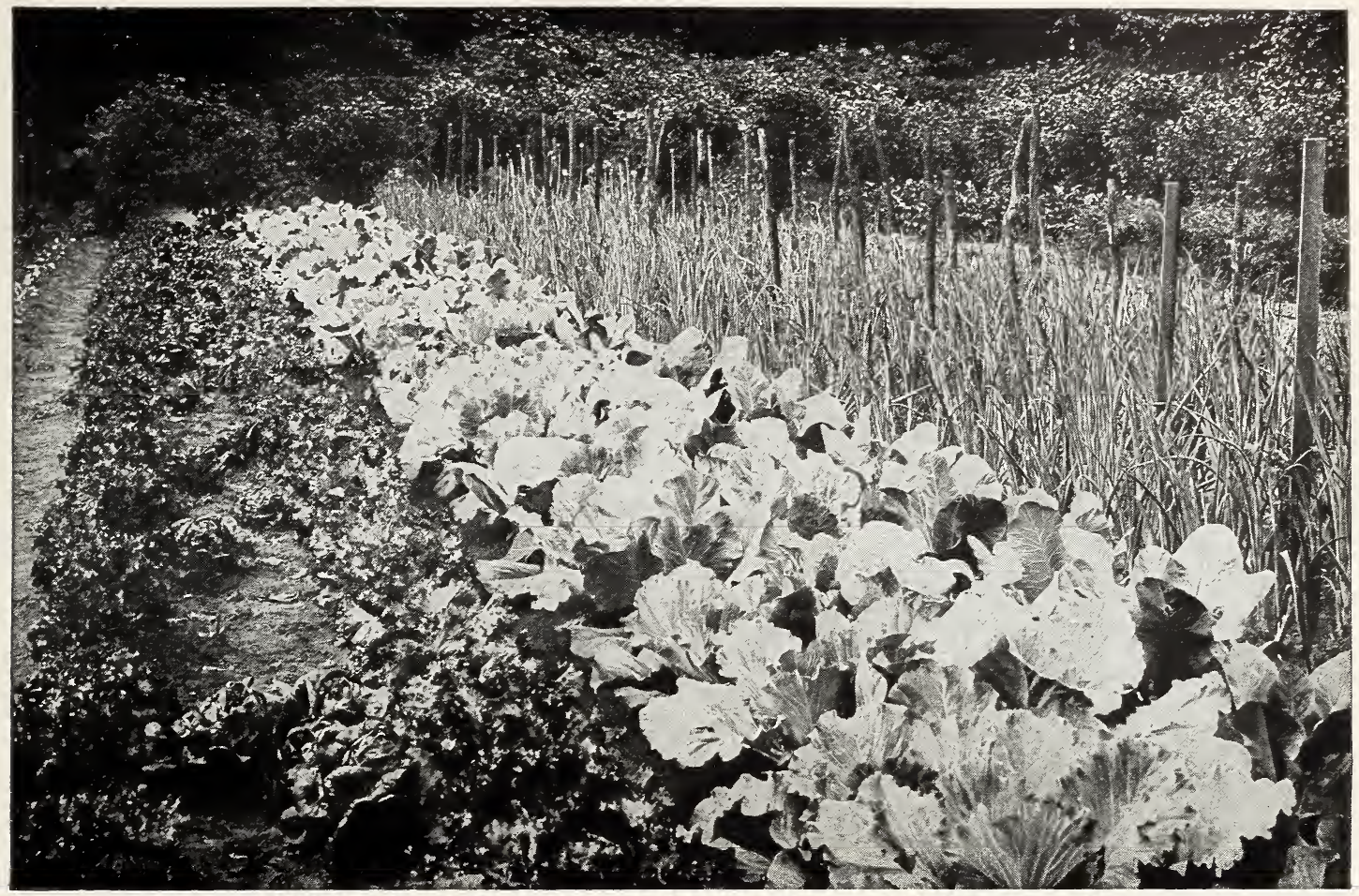

A Well Kept Vegetable Garden Is an Attractive Feature of the Home Grounds.

\section{Foreword}

In presenting my catalogue for the coming season, I wish to thank my many friends for their liberal patronage in the past, and to solicit their favors for the future.

SELECTION OF STOCK. My connection with the seed trade for more than twenty-five years should have eminently fitted me to secure stocks that will prove satisfactory to the most critical trade, as I have been able to demonstrate to those who have trusted me with their seed orders.

LOCATION OF STORE. My store will be found on the northwest corner of Washington and Eddy streets, one block from Dorrance or Westminster streets, and within a short distance of the Union Railroad Station.

SEEDS BY MAIL. For the benefit of out-of-town buyers, I pay postage on all seeds ordered in packets, ounces and one-fourth pounds. Add for prepayment of postage on large quantities at parcel post rates according to zone. Allow two pounds per quart for Peas, Beans and Corn.

PARCEL POST RATES-Ist and 2nd zones, within I50 miles, first pound $5 \mathrm{c}$., additional pounds Ic. each. 3rd Zone, I50 to 300 miles, first pound $6 \mathrm{c}$, , additional pounds, 2c. 4 th Zone, 300 to 600 miles, first pound, 7 c., additional pounds $4 \mathrm{c}$. each.

EARLY ORDERS are always advisable, as the stock of many varieties is liable to be exhausted early and many times good stocks are not obtainable later.

PACKING AND DELIVERY. I make no charge for boxes and packing and deliver all goods free within the city limits. Seamless are charged fifteen cents and small cloth bags ten cents each.

While the greatest care is exercised to have all seeds pure and reliable, I do not give any warranty, expressed or implied. If the purchaser does not accept the seeds on these terms and conditions, they must be returned at once, and the money that has been paid for same will be refunded.

WILLIS S. PINO. 


\section{The Best Vegetable Seeds}

All vegetable seeds except Peas, Beans, Corn and those otherwise mentioned, are put up in 5 cent packages. We send Free by Mail all vegetable seeds in packages, ounces and one-fourth pounds; larger quantities, add postage according to parcel post zone rates, allowing two pounds per quart for Peas, Beans and Corn.

\section{Artichokes}

Sow seeds in hot bed early in spring in rows six inches apart, transplant into boxes or pots. Plant in open ground after danger of frost is past, two by three feet between plants. Rich, sandy loam is best adapted. Sow seed in open ground in May and protect until cold weather is past and will head the second year. Large Globe or Paris. Pkt., 10c; oz., 40c.

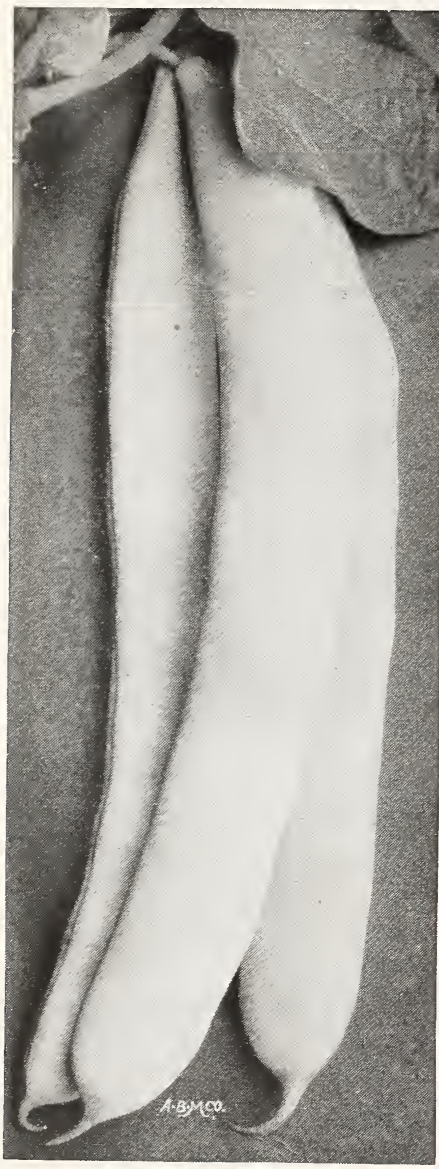

\section{Beans-Dwarf or Bush}

One quart to 100 feet of drill.

For succession bush beans should be planted at intervals of two weeks from May until August. Make drills two feet apart and two inches deep. Stringless Green Pod. Extra early, | Pencil Pod Black Wax. Pods stringless, round pod. Very round, bright yellow and enprolific and excellent quality. tirely stringless. The best Qt., 50c; 1/2 pk., \$2.00.

Extra Early Red Valentine. An excellent round green podded sort. Qt., 40c; 1/2 pk., \$1.50.

Black Valentine. Pods long, round and straight, good quality. Qt., 40c; $1 / 2$ pk., \$1.50.

Early Bountiful. Practically a stringless Yellow Six Weeks. Qt., 40c; 1/2 pk., \$1.50.

Dwarf Horticultural. An excellent shell bean. Qt., 40c; 1/2 pk., \$1.50.

Goddard, or Boston Favorite. Larger than the preceding variety. Qt., 30c: 1/2 pk., \$1.00.

Low's Champion. Recommendable as a string or shell bean. Qt., 40c; 1/2 pk., \$1.50.

Improved Golden Wax. A favorite among yellow podded varieties; pods flat. Qt., 60c; $1 / 2$ pk., \$2.40.

\section{Pole or Running Beans}

\section{One quart to 150 hills.}

The planting of pole beans should be delayed a week or more after the planting of the early dwarf sorts. Make hills about 3 feet apart and 1 to 2 inches deep, and plant 5 or 6 seeds in each hill; thin to three plants in each hill when well established. Limas should not be planted until weather becomes warm and settled. Flat beans should be placed in the soil edgewise, eye down.

Mammoth Horticultural Pole. A very prolific shell bean. Qt., 35c; Improved Golden Wax. 1/2 pk., \$1.25.

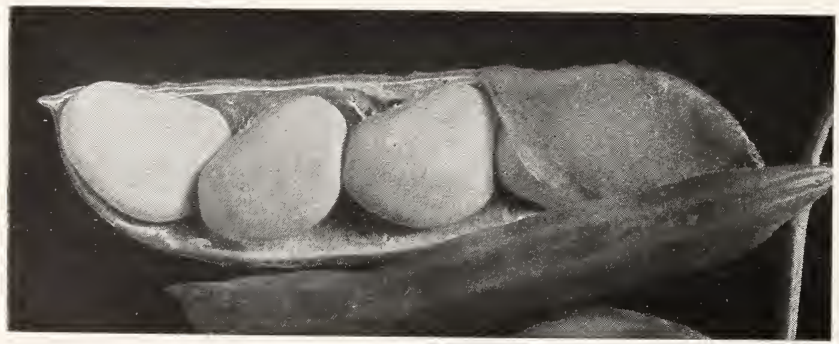

Large White Lima.
Kentucky Wonder. An excellent variety, entirely stringless, round pod. Qt., 40c; $1 / 2$ pk., \$1.50.

Golden Cluster Wax. A vellow podded variety of fine quality. Qt., 50c; 1/2 pk., \$1.75.

Scarlet Runner. Highly ornamental; also used as a table bean. Qt., 40c; 1/2 pk., \$1.50.

Large White Lima (Extra Size). The standard pole Lima. Quality excellent. Qt., 35c; 1/2 pl., \$1.25.

Dreer's Improved Lima. A short, thick bean, often called Potato Lima. Qt., 35c; 1/2 pk., \$1.25.

Sevia, or Small Lima. An excellent bean, earlier and more hardy than large Limas. Qt., 30c; 1/2 pk., \$1.00.

English Broad Windsor. The standard English bean. Qt., 35c; $1 / 2$ pk., \$1.25. 


\section{Beets}

One ounce to 50 feet of drill; 5 to 6 pounds per acre.

Sow early as ground can be worked in the spring, and for succession

follow every two weeks until July. For main crop sow last of May.

Light sandy loam well enriched with stable manure is best adapted and should be plowed and harrowed until very fine. Make drills one foot apart, and when well up thin to four or five inches in the row.

Extra Early Egyptian. A very early flat blood-red sort. Popular for first planting and forcing. Oz., 10c; $1 / 4$ lb., 30c; 1b., \$1.00.

Crosby's Egyptian. An improved strain of Egyptian Beet. Rich dark red, crisp and tender. An excellent early sort. Oz., 10c; 1/4 lb., $35 \mathrm{c} ;$ 1b., \$1.25.

Eclipse. Globe-shaped, extremely early and excellent quality. Oz., 10c; $1 / 4 \quad$ lb., 30c; 1b., \$1.00.

Detroit Dark Red. Very tender and sweet; skin dari blood red; flesh bright red; fine round shape. Excellent for main crop. Oz., 15c; 1/ 1b., 40c; 1b., \$1.50.

Edmand's Blood Turnip. Highly recommendable for main crop; uniform in size, very dark flesh, excellent quality. Oz., 10c; 1/4 1b., 30c; 1b., \$1. Dewing's Blood Turnip. A standard main crop variety of excellent shape and color. Oz., 10c; 1/4 lb., 30c; lb., \$1.

\section{Sugar Beets and Mangel Wurzels}

Sow in May or June; 5 to 8 pounds per acre.

Norbitan's Giant. A long red variety adapted to deep soil. 1/4 1b. 15c; 1b., 45c.

Mammoth Long Red. A standard sort. $1 / 4$ 1b., 15c; 1b. $45 \mathrm{c}$.

Yellow Globe. Adapted to shallow soil. 1/4 1b., 15c; 1b., $45 \mathrm{c}$

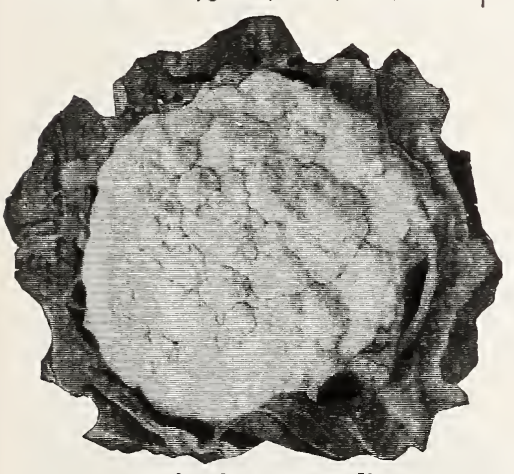

Golden Tankard. A yellow variety, formed mostly above ground; easily pulled. $1 / 4$ lb. 15c; 1b., $45 \mathrm{c}$.

Vilmorin's White Sugar. The best sugar beet for stock feeding. Price: 1/4 lb., 15̄c; lb., $45 \mathrm{c}$. autum after the early frosts.

Dwarf Improved. Compact in growth and of excellent quality. Oz., 25c; $1 / 4$ it. 75c.

\section{Borecole or Kale}

One ounce will produce about 3,000 plants. Sow in beds early in spring and trans-

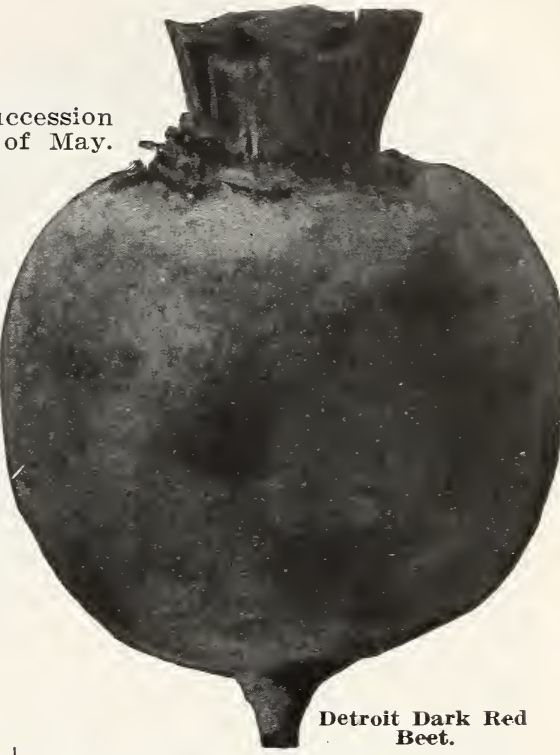

Swiss Chard or Spinach Beet

Giant Lucullus. The largest and best variety. Leaves used as greens, cooked in same manner as Spinach, and the large ribs are prepared like asparagus. Oz., 10c; $1 / 4$ lb., 35c: 1 b., \$1.25.

\section{Broccoli}

One ounce will produce about 3,000 plants.

Closely resembles Cauliflower, but more hardy and sure heading. Sow seed in May and plant out in June in rows two feet apart each way. White Cape. Heads creamy-white and of large size. Pkt., 10c; oz., 30c.

\section{Brussels Sprouts}

One ounce will produce about 3,000 plants.

The seed should be sown about the middle of May in a seed bed, and plants afterward set in rows two feet or more apart and cultivated like Cabbage. This vegetable does not require extremely high cultivation. It is ready for use late

White Cape Broccoli. plant in June; treating in same manne as Cabbage.

Dwarf Green Curled Scotch. Very dwarf and spreading, the best variety. Oz., $10 c ; 1 / 4$ lb., 30c; 1 b., \$1.00.

Siberian (Dwarf German Greens or Sprouts). Usually sown in September, to use the following spring. Oz., 10c; $1 / 4$ lb., 25e; 1b., 75e.

\section{Carrots}

One ounce to 100 feet of drill; four pounds per acre.

For early crop sow as soon as the ground can be worked; they may be sown as late as the middle of June. The drills should be one inch deep and one foot apart, thinning out to three or four inches between the plants. Carrots do best in a deeply tilled sandy loam.

Early Scarlet Horn. A favorite sort; for early summer use. Oz., 15c; 1/4 lb., 50c; lb., \$1.50.

Early French Forcing. The earliest variety grown; small, tender. Fine quality. Oz., 15c; $1 / 4$ lb., 50c; lb., \$1.50.

Danvers Half Long. The best sort for general use. Rich, deep orange color; excellent quality; roots taper to a point. A very heavy cropper. (Select stock). Oz., 15c; 1/4 1b., 50c; ib., \$1.50.

Improved Long Orange. Large variety; used for main crop. Per oz., 10c; 1/4 1b., 30c; 1b., $\$ 1.00$.
Guerande, or Ox Heart. Stumprooted; one of the most valuable varieties either for family use or market; fine flavor and color; very productive. Oz., 10c; 1/4 lb., 40c; lb., \$1.25.

St. Valery. An excellent variety for private gardens. Grows from ten to twelve inches long. Oz., 10c; 1/4 lb., 30c; lb., \$1.00.

Chantenay. A stump-rooted variety having a large shoulder; very productive. Oz., 10c; $1 / 4$ lb., 30c; lb., \$1.00.

White Belgian. Large white root; extensively grown for stock feeding. Oz., 10c; $1 / 4$ lb., 25c; 1b., $75 \mathrm{c}$.

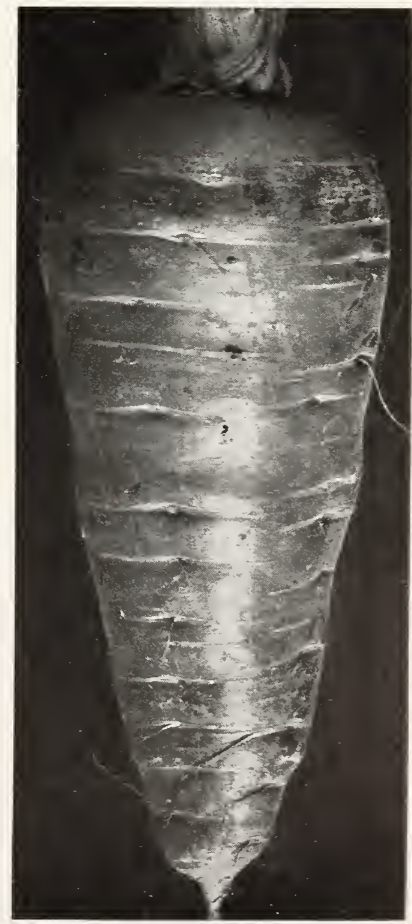

Danvers Half Long Carrot. 


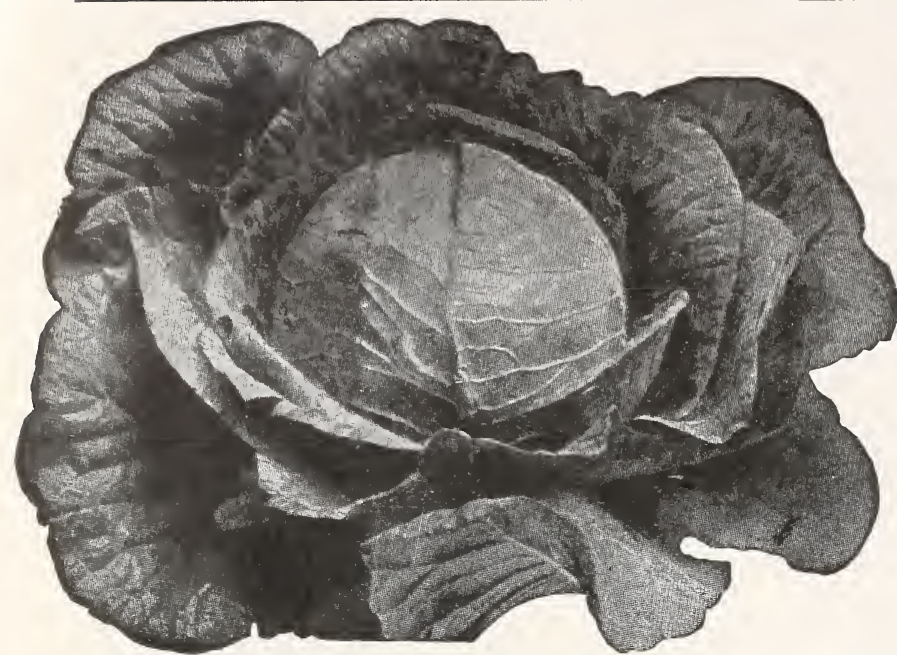

Copenhagen Market Cabbage.

\section{Cauliflower}

Cultivate as directed for Cabbage. In dry weather water liberally. Cauliflower likes a cool, moist situation.

Early Dwarf Erfurt. Very earliest dwarf variety. Plit., :0c; oz., \$2.00.

Early Snowball. A very popular early variety; for family use or market gardeners. Dwarf in habit with short outer leaves, allowing close planting. Heads white and of finest quality. Pkt., 20c; oz., \$2.00.

Early Paris. Medium size and sure heading variety. Heads are large, compact, solid and white. Plkt., 10c; oz., 75c,

Veitche's Autumn Giant. A popular, large, late variety. Pkt., 10c; oz., 75c.

\section{Chervil}

Curled Chervil. An aromatic sweet herb. The young leaves are used in soups and salads. Sow thinly in May in drills half an inch deep, one foot apart. Oz., 10c; 1/4 lb., 30c.

\section{Celery}

One ounce will produce about 1,500 plants.

Seeds may be sown in the open ground in April. Sow about half an inch deep and firmly press the soil over the seed. After the seed is up, keep carefully clear of weeds until the time of planting, in June or July. After the ground has been well prepared, plant in rows from three to four feet apart, according to variety, setting the plants about six inches apart and pressing the soil firmly about the roots. The soil best suited for Celery is a rich, moist loam.

White Plume. Excellent for early use; naturally white, requires little blanching. Oz., 25c; $1 / 4$ lb., 75c; 1 b., \$2.50.

Golden Self-Blanching. True stock. Similar to the above except that the stalks are a beautiful golden-yellow. Our stock of this Celery is endorsed by the leading market gardeners of this section. Package, 10c; oz., \$1.50; 1/1 lb., $\$ 4.50$.

Winter Queen. Robust growth, medium height. An excellent keeper and desirable for winter storage. Package, 10c; oz., 30c; 1/4 1b., 75c.

Boston Market. A dwarf branching variety. Oz., 20c; 1/4 lb., 60c: $1 \mathrm{~b}$. . \$2.00. $\$ 2.50$. 1b., \$2.50. 75c: $16 ., \$ 2.50$.

The seeds listed in this catalogue are dependable in every way. Each variety has been thoroughly tested and we know that every customer will be satisfied with his purchase.

\section{Cabbage}

One ounce will produce about 1,500 plants. For early use sow the seed in hot beds $\mathrm{m}$ February or March, or may be sown about the middle of September, and the plants intered over in cold frames. Transplant in spring, as soon as the ground can be rowed, in rows 2 feet apart, and the plants 18 inches apart in the rows. For late or vinter use, the seed should be sown in May Our Cabbage Seeds are All the Best Americal. Grown.

Early Winnigstadt. Pointed head, very hardy and sure to head. Oz., 20c; $1 / 4$ 1b., 50c; lb., \$1.50.

Early Jersey Wakefield. The best early sort. Medium size, pyramidal shape with rounded peak. Oz., 25c; 1/4 lb., 75c; lb., \$2.50.

Charleston, or Large IVakefield. Much larger than the above, but not as early. Oz., 25c; 1/4 1b., 75c; 1b., \$2.50.

Copenhagen Market. A round headed sort, early as Wakefield. A standard variety. Pkt., 10c; Oz., 80c; 1/4 lb., \$1.00.

All Seasons. A superior variety for second early and late; early as Early Summer and larger. Oz., 25c; 1/4 lb., 75c; 1b., \$2.50.

Henderson's Early Summer. The leading early drumhead variety. Oz., 25c; 1/4 1b., 75c; 1b.,

Hollander, or Danish Ball Head. Excellent winter sorts, heads very solid. Oz., 25c; $1 / 1$ 1b., 75c;

Warren Stone Mason. An improved Stone Mason;

Large Iate American Drumhead. An excellent late sort, sure heading and splendid quality. Oz., 20c; 1/4 lb., 60c; 1b., \$2.00.

Premium Flat Dntch. The standard main crop variety. Oz., 20c; 1/4 lb., 60c; 1b., \$2.00.

merican Drumhead Savoy Improved. The finest Savoy variety, finely curled, large and solid. Oz., 25c; 1/1 1b., 75c; lb., \$2.50.

Mammoth Rock Red. Large size, very solid. Oz., 30c; 1/1 1b., \$1.00; 1b., \$3.50.

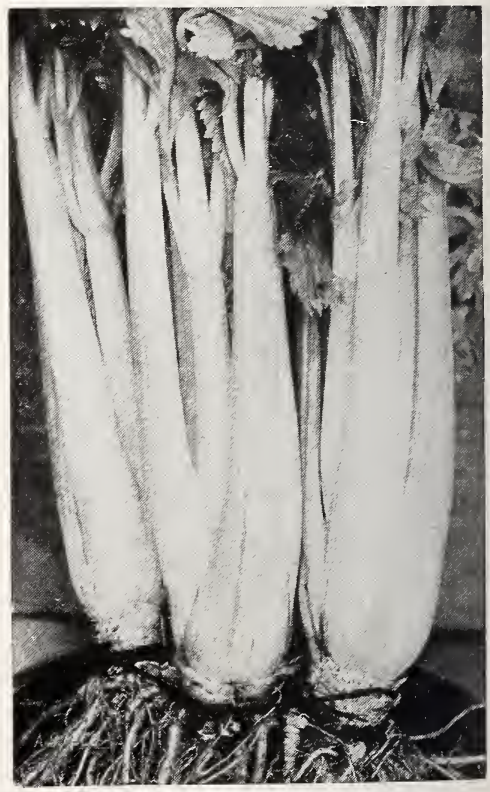

Golden Self-Blanching Celery 


\section{Sweet Corn}

One quart to 200 hills; one peck per acre.

Plant in hills three feet apart each way, and five to six kernels in a hill. Hoe often and draw soil up to the stem. Make ground rich with well rotted manure. For succession planting should be made at intervals from May to July.

\section{Choice Connecticut Grown}

Price of all varieties: Qt., 30c; 2 qts., 55c; 4 qts., \$1.00; 1 peck, \$1.75. Except where noted.

Peep o'Day. Very early, small ears, Crosby's Early. Matures after Cory; excellent quality at 35c; $1 / 2$ pk $\$ 1.25$

Early Cory. Early, good sized ears. Desirable.

Mammoth White Cory. Like the above; white cob and kernel.

Golden Bantam. Extremely hardy, allowing earlier planting than other varieties. Superior rich flavor. Qt., 45c: 2 qts., 85c; 1/2 pk., \$1.60.

Potter's Excelsior, or Squantum. Very sweet and tender; one of the finest for main crop.

\section{Field and Fodder Corn}

Iongfellow. Eight-rowed Yellow Canada. Ears average 12 to 15 inches in length. Pk.. \$1.00; bu., \$3.50.

Sanford. Ears are large and cob is small; white kernel. Pk., \$1.00; bu., $\$ 3.50$.

Evergreen Sweet Fodder. For cutting green for stock.

Stowell's Evergreen. One of the most popular varieties for main crop.

Black Mexican. Very sweet and superior quality.

Bearsfont. A very desirable late variety at 40c; 2 qts., 75c; $1 / 2$ peck, \$1.25.

Late Mammoth. Large ears, rich and sweet.

Country Gentleman. The sweetest and most tender of all varieties at $40 \mathrm{c}$; $1 / 2$ pk., \$1.25.

\section{Corn Salad or Fetticus}

Used as a salad. Is sown in early spring, in rows a foot apart, and is fit for use in six or eight weeks from the time of sowing. Large Leaved. Oz., 10c; 1/4 1b., 25c; 1b., 75c.

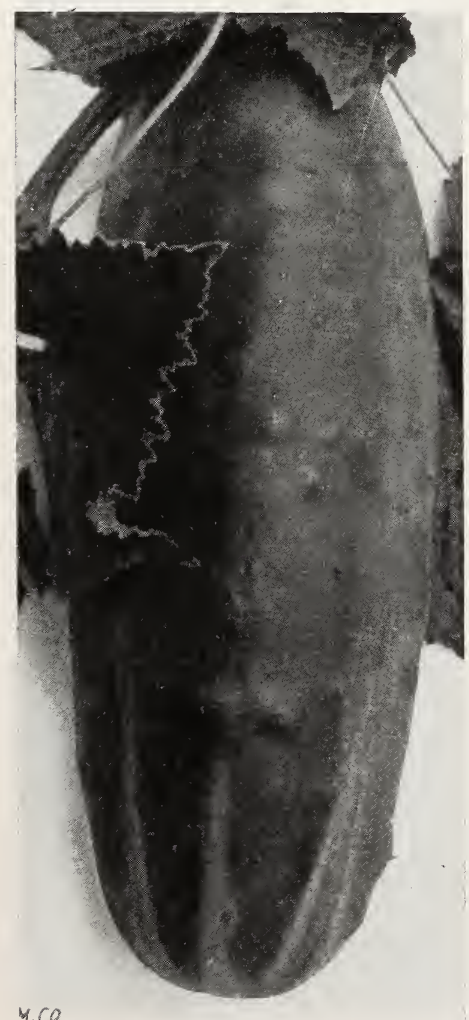

Red Cob Ensilage. Sweet, tender and juicy, producing abundance of foliage. Pk., \$1.00; bu., \$3.50.

Improved Leaming. Ears large and handsome, deep grain, small cob. Pk.. \$1.00; bu., \$3.50.

Pop Corn, Rice. Choice Eastern grown. Lb., 10c.

\section{Cress or Pepper Grass}

A well-known pungent salad; cover very slightly; sow at frequent intervals to keep up a succession; to be used before the flowers appear.

Extra Curled. Very fine; may be cut two or three times. Oz. 10c; 1/4 1b., 25c; 1b., 75c.

Upland. Hardy perennial; adapted to any soil, wet or dry. A very rapid grower and ready for use very early in the spring. Pkt., 10c; oz., 75c.

Water Cress. Hardy perennial aquatic plant. Pkt., 10c: oz., 40c; 1/4 lb., \$1.25; 1b., \$1.00.

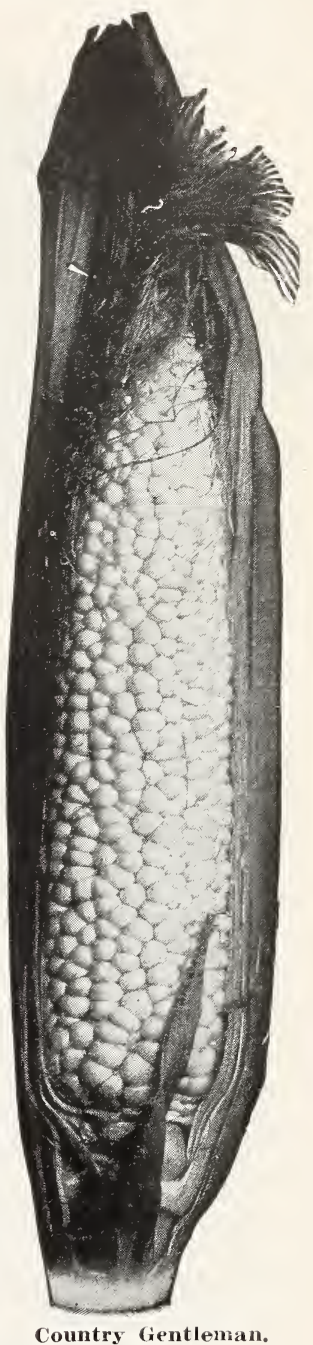

\section{Cucumbers}

One ounce to 50 hills; 2 pounds per acre.

Cucumbers succeed best in warm, rich, sandy lo $\mathrm{m}$. Plant when all danger of frost is past, in hills about four feet apart each way; the hills should be previously prepared by mixing thoroughly with the soil of each a shovelful of well-rotted manure; sow for pickling from the middle of June to the middle of July. Price, except where noted, oz., 10c: $1 / 4$ lb., 35c: 1 b.. \$1.25.

Improved White spine. One of the best varieties for table use.

White Spine Forcing. A special strain for cultivation under glass. Fruit grows very even in size; color, dark green. Oz., 30c; 1/t lb., \$1.00; lb., \$4.00.

Early Russian. The earliest in cultivation; small and productive.

Early Cluster. Length about five inches; tender and productive.

Boston Pickling. True stock: the best variety for pickling.

Green Prolific. Excellent for summer use and for pickling.

Everbearing. Small sized, very early and enormouslv productive.
Improved Long Green. 10 to 12 inches in length; dark green.

Japanese Climber. Can be grown either as an ordinary ridge cucumber or as a climber. Oz., 15c; 1/a 1b., 50c.

West India Gherkin. Small, oval shaped, for pickling. Oz. 25c.

English Frame Telegraph. For growing in hot beds. Pkt., 25c.

Do not overlook stringless Green Pod Bean, Detroit Dark Red Beet, Danvers Half Long Carrot, Golden Bantam Corn, Wayahead Lettuce, Laxtonian Peas. 


\section{Leek}

One ounce will sow 100 feet of drill.

The Leek is very hardy and easily cultivated. Sow in April in drills one foot apart, and transplant in July into rows fifteen inches apart, and six inches from each other in the rows. The soil should be rich but not fresh manured. The Leek is a member of the onion family, and the method of cultivation is like the onion, except that it should be grown deeper in the ground.

Large American Flag. The kind mostly grown for market. Oz., 20c; $1 / 4$ 1b., 50c; 1b., \$1.75.

Musselburgh. Grows to very large size. Oz., 20c; 1/4 1b., 50c; 1b., \$1.75.

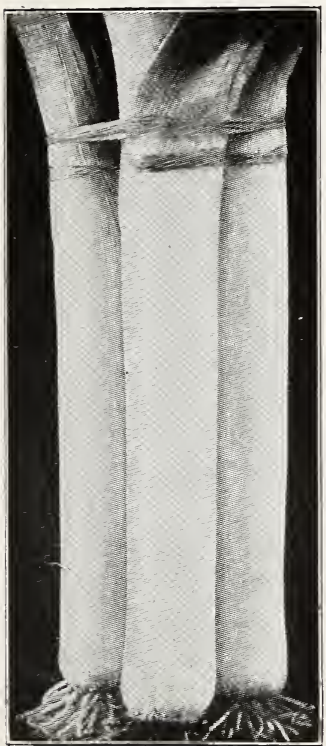

American Flag Leek.

\section{Mustard}

\section{One ounce to 80 feet of} drill.

Sow in shallow drills a foot apart, covering the seeds about a half inch deep. For succession sow every few weeks. The yo u n g leaves are used for salads or are cut and boiled like spinach, and the seeds are used for flavoring.

White. Best for salads. Oz., 10c; $1 / 4$ 1b., 15c; 1b., 40c.

Brown. More pungent in flavor than the White. Oz., 10c; $1 / 4$ Ib., 15c; 1b., 40c.

\section{Mushrooms}

"American Pure Culture Spawn," produced under the new selective method, recently discovered, the only method which makes possible the segregation of varieties is received absolutely fresh at frequent intervals from the manufacturer. This spawn will produce mushrooms of a specific variety selected with special reference to their size, color and prolificness, to the exclusion of other and inferior fungi. It absolutely eliminates all danger of raising poisonous mushrooms. We keep on hand the cream white variety. Bricks weigh from $1 \frac{1 / 4}{\text { to }} 1$ 1-3 $\mathrm{tbs}$., and will spawn 10 square feet of beds. Each, 20c.

Illustrated book, "Mushroom Culture and Pure Culture Spawn," containing the latest methods of raising, preserving and cooking mushrooms, 25c per copy, postpaid.

\section{Nasturtium}

The seeds while young and succulent are pickled and used as capers. Sow the seeds in drills one inch deep, the tall grown by the side of a fence, or supported by a trellis.

Tall Mixed. Oz., 10c; $1 / 4$ 1b., 30c; 1b., \$1.00.

Dwarf Mixed. Oz., 15c; $1 / 4$ ib., 50c; 1b., \$1.50.

\section{Okra or Gumbo}

One ounce to 75 hills.

Sow early in May, in drills two inches deep, setting the plants from two to three feet apart.

Dwarf Green. The best variety for general cultivation. Oz., 10c; 1/4 1b., 30c; 1b., \$1.00.

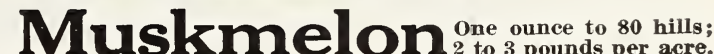

Prepare hills four to five feet apart each way; mix well with the soil in each hill a couple of shovelfuls of thoroughly rotted manure. When the weather has become warm plant from 12 to 15 seeds in each hill; afterwards thin out, leaving four good plants.

Fmerald Gem. Early. Small, flesh deep orange; very sweet. The best and most popular sort for this section. Oz., 10c; 1/4 1b., 35c; 1b., \$1.25.

Extra Early Hackensack. Earlier than Hackensack and not quite as large. Oz., 10c; 1/4 1b., 35c; 1b., \$1.25.

Tip Top. Medium size, round, yellow flesh. Oz. 10c: $1 / 4$ 1b., 35c: 1b., \$1.25

Golden Netted Gem. One of the earliest, best and most prolific small melons. Oz., 10c; 1/4 1b. 30c; 16., \$1.00.

Jenny Lind. Flesh light green, small, but very early. Oz.. 10c; 1/4 1b., 30c; 1b., \$1.00.

Miller's Cream. Skin very thin, dark green; flesh salmon and excellent flavor. Oz., 15c; 1/4 1 . . 35c; $1 \mathrm{~b} ., \$ 1.25$.

Watermelon $\begin{gathered}\text { One ounce to } 30 \text { hills: } \\ 4 \text { to } 5 \text { pounds per acre. }\end{gathered}$

Plant in hills as directed for Muskmelons, and treat in all respects the same except that the hills should be about 8 feet apart. Price, all varieties, oz., 10c; 1/4 1b., 20c; 1b., 60c.

Cole's Early. Medium size; flesh bright red; excellent quality.

Phinney's Early. Early, sweet; flesh deep red.

IKleckley's Sweet. Vines vigorous and productive; flesh bright red and exceedingly sweet.

Hungarian Honey. Very early, nearly round, dark green skin, brilliant red flesh.

Citron. For preserves only.

White Gem. Perfectly round, almost white skin, bright red flesh.

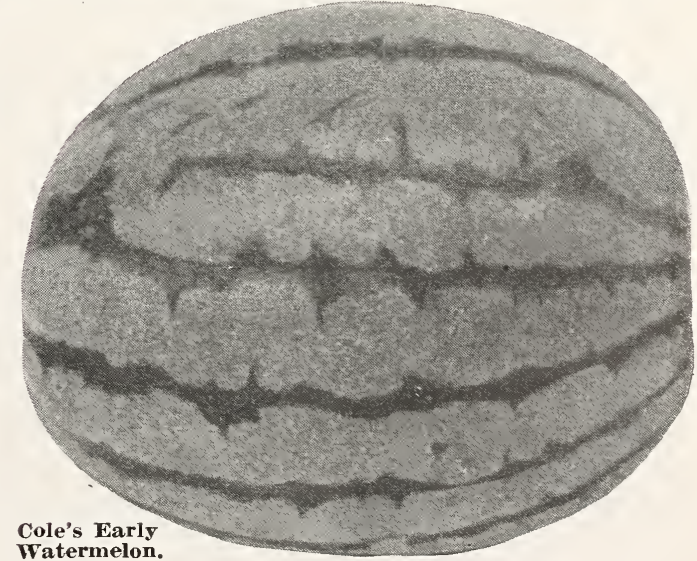




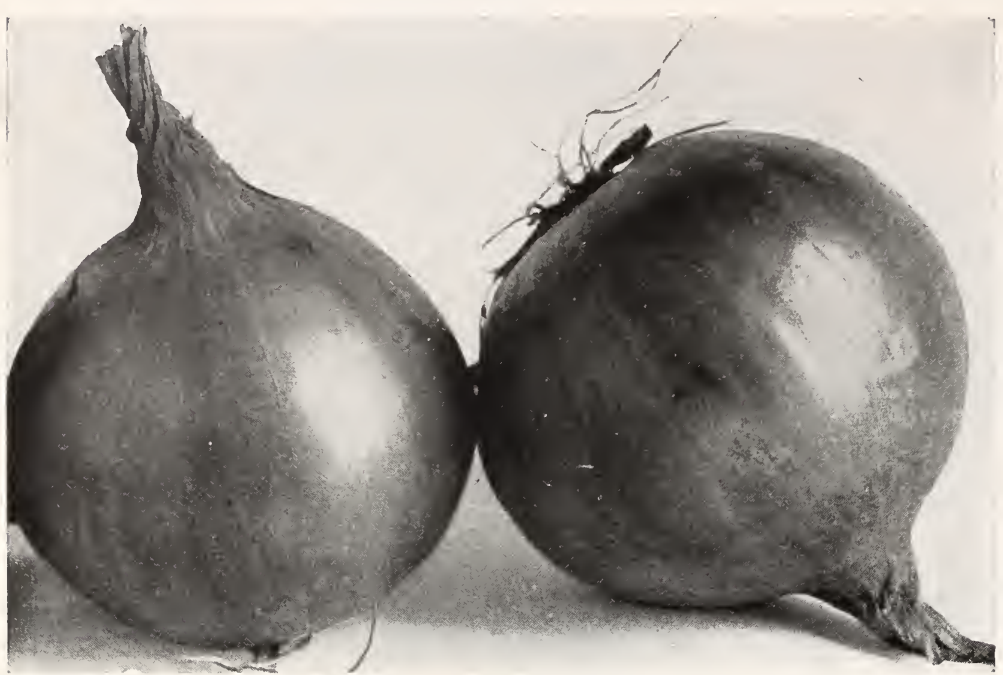

Yellow Globe Danvers.

\section{Onions}

One ounce will sow 100 feet of drill; 6 lbs. per acre.

A rather strong, deep, rich, loamy soil is considered most suitable for onion culture. Prepare ground the previous autumn by plowing or spading deeply and applying a heavy coat of well-rotted barnyard manure. Sow seed early in spring in shallow drills one foot apart, covering with fine soil, and press down by the use of a light roller or the back of a spade. Thin plants to 4 inches and keep free from weeds.

Our Onion Seed is all Eastern Grown.

Yellow Globe Danvers. True Buxton type. A standard sort, deep globe shape, large size, mild flavor and a good keeper. Oz., 25c; 1/4 1b., 60c; 1b., \$2.00.

Large Red Wethersfield. One of the most productive and longest keeping sort. Large size, flat, purplish red color. Oz., 25c; 1/4 1b., 60c; 1b., \$2.00.

Southport Red Globe. Very early, globe shape, bright red color, excellent keeper. Oz., 25c; 1/4 1b.. 60c; th., $\$ 2.00$

Southport White Globo. Large, globe shape, mild flavor and firm; a good keeper. Always commands a high price in market. Oz., 30c; 1/4 16. , $\$ 1.00 ; 16 ., \$ 3.00$.

White Portugal. Excellent for family use, and recommended for pickling. Oz., 25c; $1 / 4$ 1b., 75c; 1b., \$2.75.

Prizetaker. Globe shape, very large size, extremely mild flavored; is most satisfactory when sown early in hot bed and transplanted. Oz., 20c; 1/4 1b., 60c; 1b., \$2.00.

\section{Onion Sets}

(Prices variable.)

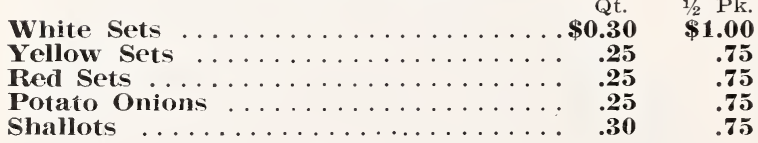

\section{Parsley}

One ounce will sow 150 feet of drill.

Sow thickly in drills a foot apart and half an inch deep early in the spring, having soaked the seed in tepid water a few hours.

Champion Moss Curled. Fine and unsurpassed for garnishing. Oz., 10c; 1/4 ib., 30c; 1b., \$1.00.

Plain Leaved. Excellent flavor. Oz., 10c; 1/4 1b., 30c; 1b., \$1.00.

Hamburg Rooted. Fleshy vegetable root for soups, etc. Oz., 10c; $1 / 4$ 1b., 30c; 1b., \$1.00.

\section{Parsnips}

(One ounce will sow $\geqslant 00$ feet of drill; 5 ibs. per acre.

Sow as early as possible, half an inch deep, and press the soil firmly over the seed; succeeds best in a rich, sandy loam.

Hollow Crown, or LongSmootl. The standard sort for general use. Oz., 10c; $1 / 4$ 1b., 25c; th.. 60c.

\section{Peppers}

One ounce will produce about 2,000 Plants.

Sow the seed in March or April in a hot bed, and transplant to open ground as soon as the weather is quite warm, in rows about 20 inches apart and 15 inches apart in the rows. A warm, sandy loam is best. Prices, except where noted, oz., 30c; $1 / 4$ ib., \$1.00; 16., $\$ 3.00$.

Giant Crimson. The earliest very large sweet pepper. Plant vigorous, upright, larger than Chinese Giant and more productive. Pkt. 10c; oz., 50c; $1 / 4$ 1b., \$1.50.

Sweet Mountain. Large size, regular, handsome shape, mild flavor, very early.

Large Bell. A standard sort, large size, mild flavor.

Squash. Medium size, productive.

Ruby King. Very mild, fruits 4 to 6 inches long; excellent for stuffing; a very popular sort.

Long Red Cayenne. Bright red, slender pods, very pungent.

Chili. Very small, red, very pungent.

\section{Potatoes}

All the leading varieties, choice Maine grown stock, at lowest market prices.

The seeds listed in this catalogue are depend. able in every way. Each variety has been thoroughly tested and we know that over'y customel will be satisfied with his purchase.

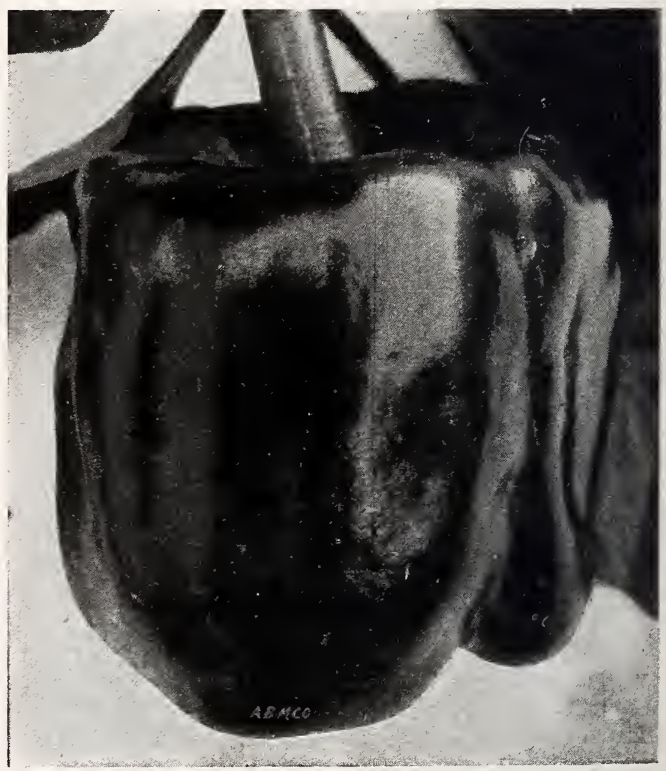

Large Bell Pepper. 


\section{Peas}

One quart will plant about 100 feet of drill; 11/2 bu. per acre. Plant the extra early smooth varieties as soon as the ground can be worked; and the wrinkled sorts soon as the ground becomes warm. Make rows for dwarf varieties two and one-half feet apart and for tall sorts three feet apart.

Laxtonian. New dwarf, early, large podded variety; earlier than Gradus. Qt., 40c; $1 / 2$ pk., \$1.50.

Little Marvel. Very early, dwarf, even growth; about 15 inches high. Pods average $2 \frac{1}{2}$ inches long and well filled. Qt., 40c; 1/2 pk., \$1.50.

Gradus. A variety rivaling the first earlies; producing pods and peas equal to the large marrow sorts. Unexcelled in quality and flavor. Qt., 35c; $1 / 2$ pk., \$1.25.

Thomas Laxton. Resembles the Gradus in size of pod, but of darker color. Qt., 30c; 1/2 pk., \$1.00.

New York Market. Very early and productive. A general favorite among the market gardeners; robust in growth; height $2 \frac{1}{2}$ feet. Qt., 30c; 1/2 pk., \$1.00.

Alaska, or Earliest of All. The earliest pea in cultivation: matures nearly its entire crop at one picking; height $21 \frac{1}{2}$ feet. Qt., 30c; 1/2 pk., \$1.00.

American Wonder. One of the earliest wrinkled peas, dwarf and robust in growth, pods long and well filled; height 10 to 12 inches. Qt., 30c; 1/2 pk., \$1.00.

Sutton's Excelsior. One of the largest podded dwarf sorts; excellent quality and heavy cropper. Qt., 35c: peck, \$1.25.

Nott's Excelsior. An excellent dwarf wrinkled pea, robust, vigorous. Peas and pods large. Qt., 30c; 1/2 pk., \$1.00.

New Dwarf Champion. A sort with all the merits of the Champion of England; height 26 inches; matures little after Little Gem. Qt., 30c; 1/2 pk., \$1.00.

McLean's Advancer. A standard variety of excellent quality. Qt., 30c; 1/2 pk., \$1.00.

Telephone. A very popular variety, height $3 \frac{1}{2}$ feet. Pods 5 to 7 inches long, containing 8 to 12 peas of unequalled flavor. Qt., 30c; 1/2 pk., \$1.00.

Everbearing. A branching and everbearing sort. Height 3 feet; pods long, well filled. Qt., 30c; 1/2 pk., \$1.00.

Champion of England. A standard tall growing sort; productive and good quality. Qt., 30c; 1/2 pk., \$1.00.

Black-Eyed Marrowfat. Hardy and productive, an old standard; height 4 feet. Qt., 25c; $1 / 2$ pk., 75c.

Giant Sugar. Pods 5 to 6 inches long; cooked same as string beans. Qt., 35c; 1/2 pk., \$1.25.

\section{Pumpkins}

Pumpkins are usually planted in fields of corn or potatoes, but may be profitably raised in fields by them-

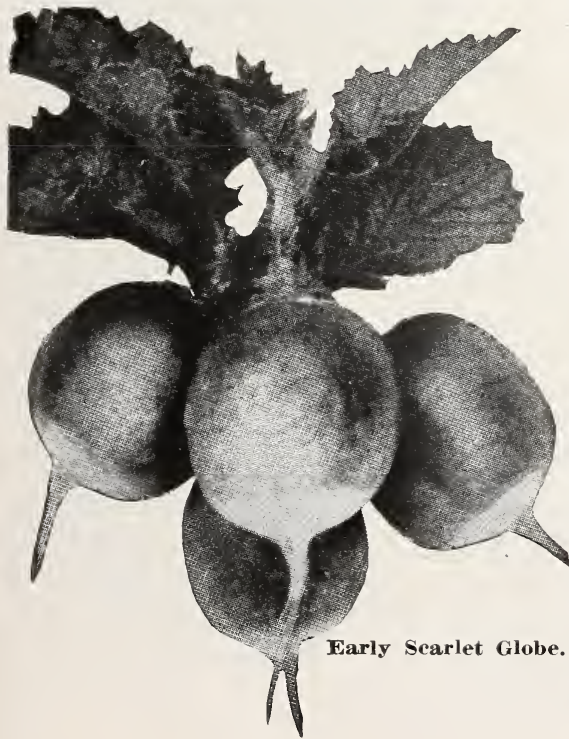

selves. Sow first of May in hills eight feet apart.

Yellow Sugar. Very sweet; an excellent table sort. Oz., 10c; $1 / 1$ 1b., 20c; 1b., 60c.

Connecticut Field. For feeding stock. Oz., 5c; 1/4 1b., 15c; 16., 40c.

Large Cheese Flat, One of the best varieties for family use. Oz.. 10c; $1 / 4$ 1b., 20c; ib., 60c.

\section{Radishes $\begin{gathered}\text { one ounce will sow } \\ 100 \text { feet of drill. }\end{gathered}$}

Radishes require a light, rich, sandy soil. For an early supply sow in a hot bed in February, eare being taken to give plenty of ventilation. For a successive supply, sow from the middle of March until September, at intervals of two or three weeks.

Farly Scarlet Globe. For forcing in greenhouses, hot beds and cold frames or open-ground sowing, this is one of the very best. Globe shaped, fine scarlet color, crisp, mild and tender. Small tops. The market gardeners' favorite. Oz., 10c; 1/4 1b., 25c; ib., 75c

Price of following varieties: Oz., 10c; $1 / 4$ ib., 20c; $1 \mathrm{~b} ., 60 \mathrm{c}$

Early Scarlet Turnip. A standard variety for market or family use.

French Breakfast. Oliveshaped, bright scarlet, white tipped. A favorite sort.

cong Scarlet Short Top. Long smooth, crisp and tender. Scarlet Turnip, White Tipped. Very early, excellent quality.

White Box. A turnip shaped white sort, quick growing. excellent quality.
White Giant Stuttgart. Top shape, white skin and flesh, summer variety, but does not become pithy until late and can be stored for winter.

Olive Shaped Scarlet. Firm, crisp, good flavor.

Long Black Spanish. An excellent winter sort

Round Black Spanish. A winter variety.

Icicle. Long, white, rapid growing. 


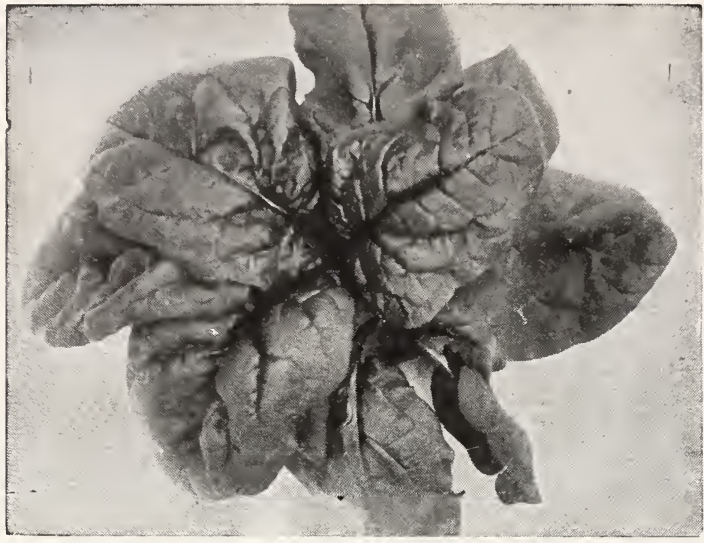

Victoria Spinach.

\section{Spinach}

One ounce to 100 feet of drill.

For summer use sow early in March in drills fifteen inches apart, and for succession at intervals of a fortnight. For winter use, sow late in August. The soil should be heavily manured and deeply trenched.

Giant Thick Leaved. The best for spring or fall sowing. Oz., 10c; 1/4 16., 25c; 1b., 80c.

Bloomsdale. Savoy leaved, for sowing in the fall for early spring use. Oz., 10c; 1/4 1b., 25c; 1b., $80 \mathrm{c}$

Victoria. Leaves large, thick, dark green. A favorite for spring or

\section{Squash}

Bush sorts, one ounce to 50 hills; 6 lbs. per acre.

\section{Running sorts, one ounce to 16 hilis; 4 lbs. per acre.}

The Squash is a very tender vegetable, sensitive of cold, and cannot in our climate be planted before the middle of May. Plant in rich soil, in hills prepared similar to those for Cucumbers. All sorts, thinned to not over three plants to a hill.

Giant Summer Crookneck. Larger than the ordinary summer crookneck. Oz., 10c; 1/4 1b., 35c; Ib., \$1.25.

White Bush Scallop. Early; a good market sort. Oz., 10c; $1 / 4$ ib., $25 \mathrm{c}$; 1b., $80 \mathrm{c}$.

Yellow Bush Scallop. Yellow, flat, scalloped edge. Oz., 10c; $1 / 4$ ib. 25c; th., 80c.

American Turban. A favorite late variety. Oz., 10c; 1/4 1b., 25c; Ib., 80c.

Early Prolific Marrow. The earliest and most productive fall and early winter variety. Oz., 10c; 1/4 1b., 25c; 1b., 80c.

\section{Salsify or Oyster Plant}

One ounce to 50 feet of drill.

The Salsify has a long white, tapbling a small parsnip; when properly cooked it has the flavor of an oyster, and is a g o o d substitute. Sow early in drills 15 inches apart; cover the seeds an inch and a half deep.

Sandwich Island.

Grows to a large size; very mild flavor. $\mathbf{O z}$. 20c; 1/4 1b., 60c: 11)., \$2.00. ering root, resem-

Boston Marrow. A good keeping winter sort. Oz., 10c; $1 / 4 \quad 16 .$, 25c; 1b., 80c.

Golden Bronze. Dark grayishgreen skin; bright yellow flesh; fine grained. Oz., 10c; $1 / 4 \mathrm{Ib}$., 25c; 1b., 80c.

Delicious. Medium size, thick, bright yellow flesh; excellent flavor. Oz., 15c; 1/4 16., 50c; 1b.,

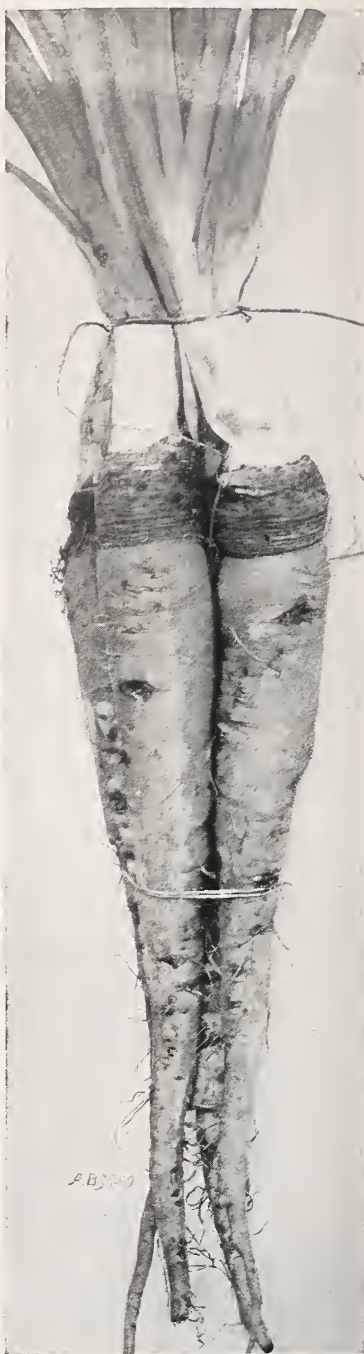

Salsify or Oyster Plant. $\$ 1.50$.

Chicago Warted Hubbard. A popular selection of the well known Hubbard, having dark green warted shell. Large size and excellent quality. Oz., 10c; 1/4 1b., 30c; 1b., $\$ 1.00$.

Golden Hubbard. Similar to the standard sort except in color. Oz., 10c; 1/4 1b., 30c; 1b \$1.00.

Hubbard. The standard winter squash. Oz., 10c; 1/4 1b., 30c; 1b., $\$ 1.00$.

Essex Hybrid. A fine fall variety. Oz., 10c; $1 / 4$ tb., 30c: 1b., \$1.00.

Mammoth Chili. Enormous size, orange yellow flesh. Oz., 15c; $1 / 4$ 1b., 35c; 1b., \$1.25.

\section{Tobacco}

One ounce will produce plants for one acre.

Sow broadcast in hot beds or open ground soon as ground can be worked. Keep free from weeds and water freely in dry weather. Set out about June 1st three feet apart on highly manured ground.

Connecticut Seed Leaf. Pkt., 10c; oz. 30c.

Havana. Pkt., 10c; oz., 40c. 


\section{Tomatoes}

One ounce will produce about 2,000 plants.

The seed should be sown in a hot bed about the first week in March, in drills five inches apart and half an inch deep. When the plants are about two inches high, set out in boxes, three inches deep, four inches apart, in another hot bed, or pot singly. If transplanted a second time will be stocky and branching. When the weather has become mild, transplant into warm, light, rich soil, four feet apart.

Price, except where noted: Oz., 30c; $1 / 4$ 1b., 85c; 1b., \$3.00.

Comet. Foreing or out-door planting. Pkt., 15c; 1/2 oz., 50c.

June Pink. Extra early purple fruited; very desirable.

Earliana. The earliest large red tomato. A favorite among market gardeners.

Chalk's Early Jewel. Medium early, bright scarlet, ripening up to the stem without cracks or green core.

Acme. Very early, smooth, color purplish pink. Beauty. Large smooth, early, dark purplish pink.

Perfection. Early, regular and productive, reddisle scarlet.

Iivingston's Globe. Large purple fruit, excellent quality.

Dwarf Champion. A distinct variety; robust, short jointed; fruit early, medium size, crimson color.

Stone. A remarkable main crop variety; robust, solid and very little seed capacity, very productive and quality is unexcelled.

Dwarf Stone. The largest fruited of the dwarf sort. Color, bright scarlet.

Ponderosa. The largest variety in cultivation. Oz., 40c; $1 / 4$ 1b., \$1.25.

Golden Queen. A large, smooth, yellow variety. Strawberry (Husk). A favorite preserving sort.

Our display of Vegetable and Flowering Plants is worthy of your attention.

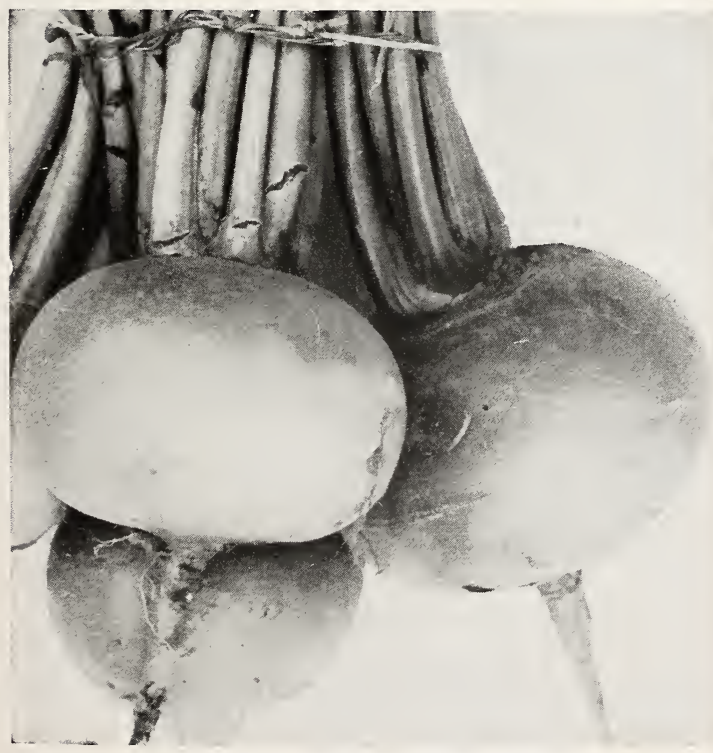

Extra Early Purple Top Milan Turnips.

Acme Tomatoes.

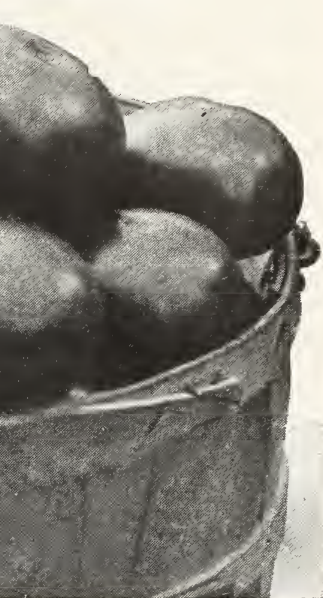

\section{Turnips}

One ounce will sow 150 feet of drill: 1 lb. per acre in drills: 2 to 3 lbs. broadieast.

For summer use, sow early in the spring in drills and thin out to eight inches. For fall and winter, sow from July to September. Rutabagas should be sown in June or early in July, in drills eighteen inches apart; thin out when large enough six to nine inches apart in drill, according to size.

Extra Early Purple Top Milan. The earliest Turnip. White, flat, medium size. Oz., 10c; 1/4 1 ., 30c: 1b., \$1.00.

Red Top Strap Leaf. A popular quick growing sort. Oz., 10c; 1/4 1b., 15c; 1b., $40 \mathrm{c}$.

White Fgg. Rapid growth, pure white, egg shaped, fine grained. Oz., 10c; 1/4 1b., 20c; 1b., 60c.

Golden Ball. Medium size and excellent quality. Oz., 10c; 1/4 1b., 20c; 1b., 60c.

Cow Horn. Flesh white, fine grained, a good table sort. Oz., 10c; 1/4 1b., 20c; 1b., 60c.

Budlong White Rock. Much smoother than the old type, white flesh, mild and sweet. Oz., 10c: $1 / 4$ 1b., 20c; 1b., 60c.

Sweet German. Flesh white, sweet and mild flavored. Oz., 10c; 1/4 1b., 20c; 1b., 60c.

Sweet German. Flesh white, sweet and mild flavored. Oz., 10c; 1/4 1b., 20c; 1b., 60c.

Improved American. Yellow flesh, excellent quality. Oz., 10c; $1 / 4$ 1b., 20c; 1b., 60c.

\section{Vegetable Roots and Plants}

Asparagus. Conover's Colossal, Palmetto. Twoyear-old roots. Doz., 20c; 100, \$1.00. Special prices for large quantities.

Chives Plants. 15c each; doz., $\$ 1.50$.

Rhubarb Roots. Victoria, large. 15e each: Doz., \$1.50.

Horse Radish Sets. Doz, 10c; 100 for 60c.

Cabbage, Cauliflower, Egg Plant, Celery, Pepper, Iettuce, Tomato Plants in season at low prices.

\section{Herbs}

Packages, 5 cents.

Anise, 15c per oz. Basil, 20c oz.; Caraway, 10c oz.; Catnip. 25̃c oz.; Dill, 15̄e oz. Fennel, 15c oz.; Lavender, 20c oz.; Mar. joram Sweet, 20c oz.; Sage, 15c oz.; Sav ory, Summer, $15 c$

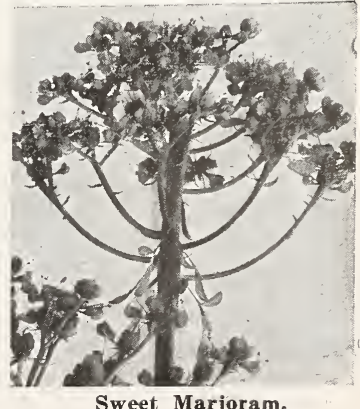




\section{Bird Seed}

\section{Extra Recleaned.}

Lh.

Canary Sicily

$\$ 0.15$

$3 \mathrm{lb} .10 \mathrm{lb}$.

Rape, Ger. Summici. . . . . . . . . 12

Hemp, Russian .......... 12

Sunflower ................10

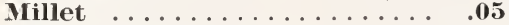

Rice, Uninilied............ 10

$\$ 0.40 \$ 1.25$

$.35 \quad 1.10$

.35 1.10

$.30 \quad .90$

$.15 \quad .45$

.25

.85

Lettuce

.30

\section{Grains, Etc.}

Subject to Change in Price.

Buckwheat, Japanese Early. Immense cropper. Bu., \$2.25.

Barley. Two-rowed. Select stock. Bu., \$2.00

Beardless. Earlier than any bearded sort, better feeding and as productive. Bu., \$2.00.

Spring Rye. Sow 1 to $1 \frac{1 / 2}{b u}$. to the acre. Bu., $\$ 2.50$.

Oats. Various sorts at market price.

Canada Field Peas. Valuable for cattle feeding, excellent for ensilaging, or sown broadcast in the spring and harrowed in. Bu., \$3.75.

Vetches. Spring sown, mixed with oats for soiling. Lb., 20c; 10 lbs., \$1.50; bu., \$6.00.

Vetches. Winter sown, in fall with rye for early fodder or plowing under. Lb., 30c; 10 lbs. $\$ 2.75 ;$ bu., \$15.00.

Rape, Dwarf Essex. A prolific foliage plant for sheep pastures. Sow 5 pounds to the acre in drills. Lb., 15c; 10 lbs., \$1.25.

\section{Grass Seeds}

Prices May Change as the Season Advances.

Rhode Island Bent. One of the best grasses for lawns in adapting itself to almost any soil, dry, moist or sandy. Valuable for permanent pastures. Per 1b., 45c.

Kentucky Blue (Poa Pratensis). A superior grass for pastures and lawns. Succeeds well in all soils and stands dry weather well. Lb., 25c.

Orchard Grass (Dactylis Glomerata). One of the earliest grasses and very hardy. Should be sown with Red Clover, as it blossoms about the same time. It is very productive and makes excellent hay. Grows well in shady woodlands, but do not use it for lawns. Per lb., 30c.

Timothy (Phleum Pratense). A variety well known and highly appreciated. Produces large hay crops if grown on moist clayey soil. Market price.

Red Top (Agrostis Vulgaris). A hardy perennial grass, succeeding best on moist land. Used extensively in all pasture mixtures, remaining green the greater part of the year. Recleaned, per 1 lb., 25 c.

Sweet Vernal (Anthoxanthum Odoratum). A perennial grass used in pasture mixtures. Per 1b., $75 \mathrm{c}$.

Tall Meadow Oat Grass (Avena Elatior). An early grass much relished by cattle, and produces an abundant supply of foliage. It is hardy and valuable for pasture. Per lb., 30c.

Hard Fescue (Festuca Duriuscula). One of the best dwarf grasses; excellent for dry soil. Hardy and withstands long periods of drought. Per 1b., 40c.

Meadow Fescue (Festuca Pratensis). A valuable grass for permanent pastures. Very productive and nutritious. Per lb., 25c.
Crested Dog's Tail (Cynosurus Cristatus). An excellent grass for hilly situations and shady parts of lawns, thriving best on rich, moist land. Per lb., 40c.

Rough Stalked Meadow Grass (Poa Trivialis). Produces an abundant crop of highly nutritious herbage. Grows well on rich, moist lands and sheltered situations. Per lb., 50c.

Sheep's Fescue (Festuca Oriana). An excellent grass for sheep pasture. Perfectly hardy, dwarf, compact growth. Per lb., 40c.

Fine Leaved Fescue (Festuca Ovina Tenuifolia). Adapted to dry soils. Per lb., 45c.

Red Fescue (Festuca Rubra). Suitable for sandy soils and at the seashore. Per lb., 50c.

Meadow Foxtail (Alopecurus Pratensis). One of the earliest and best pasture grasses; grows rapidly when cut or eaten down by stock. Should only be sown with other grasses. Per lb., 60c.

Creeping Bent (Agrostis Stolonifera). One of the best lawn grasses; succeeds well in deep soils. Per. 1b., 45 c.

Wood Meadow Grass (Poa Memoralis). Chiefly used for shaded positions in lawns and woodland parks, where other grasses will not grow. Per 1b., 60c.

English Rye Grass (Lolium Perenne). A very nutritious, rapid growing grass. Valuable for meadows and pastures. Per 1b., 20c.

\section{Clovers}

Alfalfa (Lucerne). Requires a deep, rich soil, and in such will produce several crops each season: one of the best green fodder plants; 10 to 15 1bs. to the acre. Per 1b., 30c.

Alsike Clover (Trifolium Hybridum). Resembles in growth, duration, etc., the Red Clover: thrives well in cold, wet and stiff soils; $10 \mathrm{lbs}$. to the acre. Per 1b.., 30c.

Medium Red Clover (Trifolium Pratense). Is a perennial, but of very few years' duration; is considered the most nutritious of all species and most valuable in moist locations. Market prices.

White Clover (Trifolium Repens). Valuable for lawns and pastures. Per tb., 60c.

Crimson Clover (Trifolium Incarnatum). Sown at the last of summer or early autumn; it furnishes a very early green fodder; excellent for soiling; 20 lbs. to the acre. Per 1b., 20c.

\section{Millets}

Southern Golden. Medium early; height 3 to 5 feet; heads closely condensed; spikes very numerous; seeds round, golden yellow, in rough, bristly sheaths. Per bushel (50 1bs.), \$2.25.

Hungarian Millet (Panicum Germanicum). One of the most valuable annual soiling plants. It will grow in any ordinary soil, withstands drought well, and in this latitude may be sown as late as the first day of July, and produces a large green crop; $1 \frac{1 / 2}{2}$ bushels to the acre. Per bushel (48 1bs.), \$2.00.

Japanese. A new millet, very productive if sown early and cut; usually produces a good second crop. Has produced six tons dry hay per acre. Sow one bushel to the acre. Per 1b., 10c; per 100 lbs., \$8.00.

\section{Lawn Grass Mixtures}

\section{See 2nd page Cover.}

Park Lawn Grass Mixture. 1/2 1b., 20c; 1 1b., 35c; 2 1bs., 60c; 100 1bs., \$25.00.

Shady Nook Grass Mixture. 1 qt., 30c; 1/2 pk. $\$ 1.00 ; 1$ pk., \$1.75; 1 bu., \$6.00. 


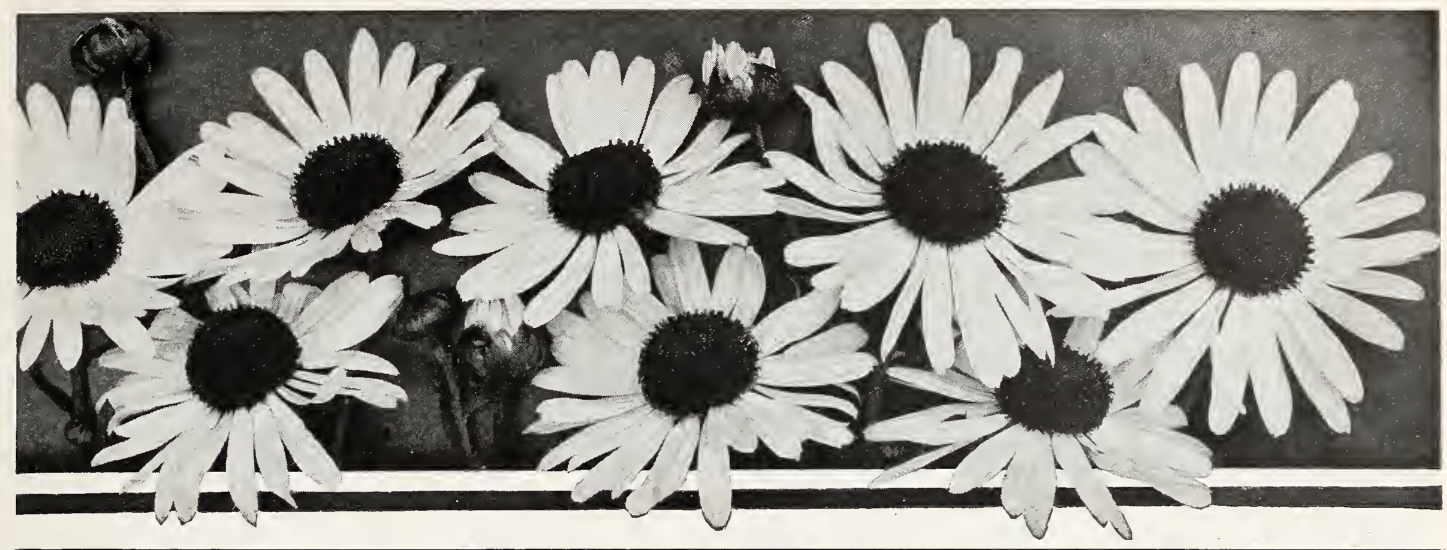

\section{Selected Flower Seeds}

Our stock of flower seeds has been selected to supply the wants of a critical florists' trade and our customers may be sure of receiving nothing but seeds of the finest quality. All flower seeds in packages. ounces, and $1 / 4$ pounds mailed free at prices; larger quantities, add at parcel post zone rates.

\section{Asters}

One of the most highly prized and best known annuals. Seed should be sown from middle of March to first of May, and when an inch high, transplant into pots or boxes and plant out in open ground last of May. Ground should be well manured and thoroughly worked.

\section{SEMPLE'S BRANCHING.}

Blossoms are large, loose and graceful, resembling Chrysanthemums. Branching in habit and late flowering. A superb variety. $2 \frac{1}{2}$ feet.

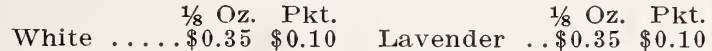
Shell Pink.. $.35 \quad .10$ Purple .... $.35 \quad .10$

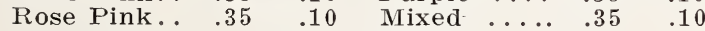

\section{GIANT COMET.}

Flowers extra large, with long, wavy, curled petals, long stems and branching habit. $2 \frac{1}{2}$ feet.

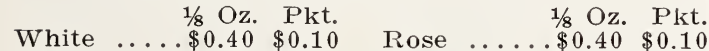
Light Blue. $.40 \quad .10$ Dark Biue... $.40 \quad .10$ Shell Pink. $.40 \quad .10$ Mixed ..... .40

\section{'TRUFFAUT'S PAEONY FLOWERED PERFECTION.}

A favorite class, with incurved petals, large, round and well formed. Height 18 in. to 2 feet.

$$
1 / 8 \text { Oz. Pkt. }
$$

Pure White.. $\$ 0.40 \$ 0.10$ Brilliant Pink .40 .10 Light Blue... $.40 \quad .10$

\section{VICTORIA.}

A grand variety, flowers large, perfect form, and beautifully imbricated. Height 15 to 18 inches.

$$
1 / 8 \text { Oz. Pkt. }
$$

Pure White. $\$ 0.50 \$ 0.10$

Pink ..... $\quad .50 \quad .10$

Light Blue. $\quad .50 \quad .10$

Scarlet ... \$0.50 $\$ 0.10$ Peach Elos-

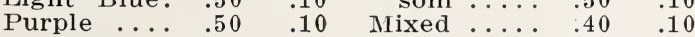

\section{QUEEN OF THE MARKET.}

The earliest flowering variety stems long and an excellent variety for cutting.

$$
1 / 8 \text { Oz. Pkt. }
$$

White $\ldots \ldots \$ 0.25 \$ 0.10$

Flesh Color. $\quad .25 \quad .10$

Light Blue $\$ 0.25 \quad \$ 0.10$

Dark Blue. . $.25 \quad .10$

$\begin{array}{llllll}\text { Rose } \ldots . . .2 & .25 & .10 & \text { Mixed } \ldots . . & .25 & .05\end{array}$

\section{OSTRICH PLUME.}

A new class resembling the Comet. Extremely beautiful. White or Rose. Pkt. 10c.
ABRONIA Umbellata (Sand Verbena). trail ing annual; rose color; adapted to dry,

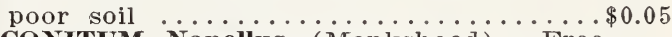
ACONITUM Napellus (Monkshood). Free flowering hardy plants, does well under shade of trees; 2 feet..............\$0.05

ACROCLINIUM. Graceful everlastings for winter bouquets. Flower heads should be gathered when young if to be preserved.

Album, white, 1 foot................ . 05

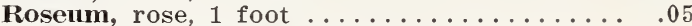

ADLUMIA Cirrhosa. Beautiful climber, flow-

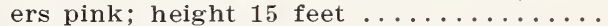

ADONIS Aestivalis (Flos Adonis). Very attractive annual, with bright crimson flow-

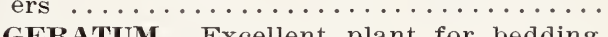

AGERATUM. Excellent plant for bedding, very free blooming annual.

Imperial Dwarf, Blue, $3 / 4$ feet. $1 / 4$ oz., $25 \mathrm{c} \ldots \quad .05$ White, $3 / 4$ feet ........... .05 Mixed, $1 / 4$ oz., $25 \mathrm{c} \ldots \ldots \ldots .05$

Mexicanum, blue, $11 \frac{2}{2}$ feet................ . 05

Lasseauxi, rose colored, 1 foot.

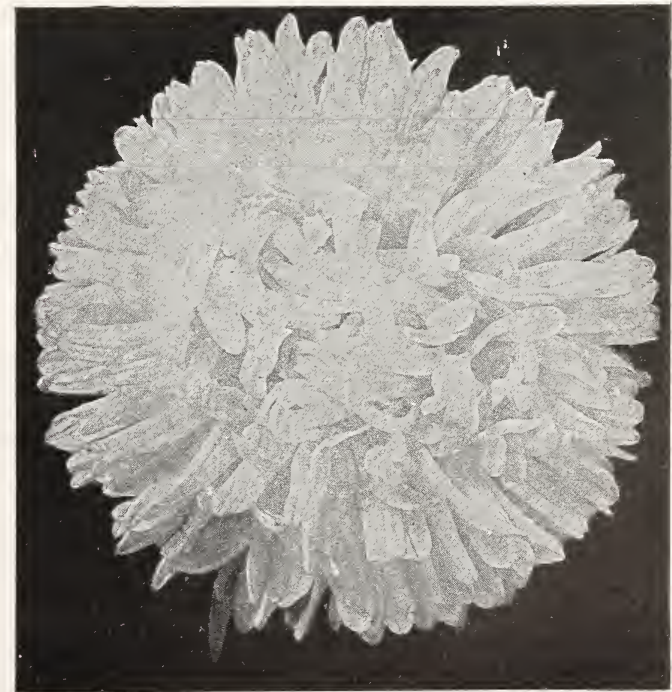

Aster, Semple Branching. 


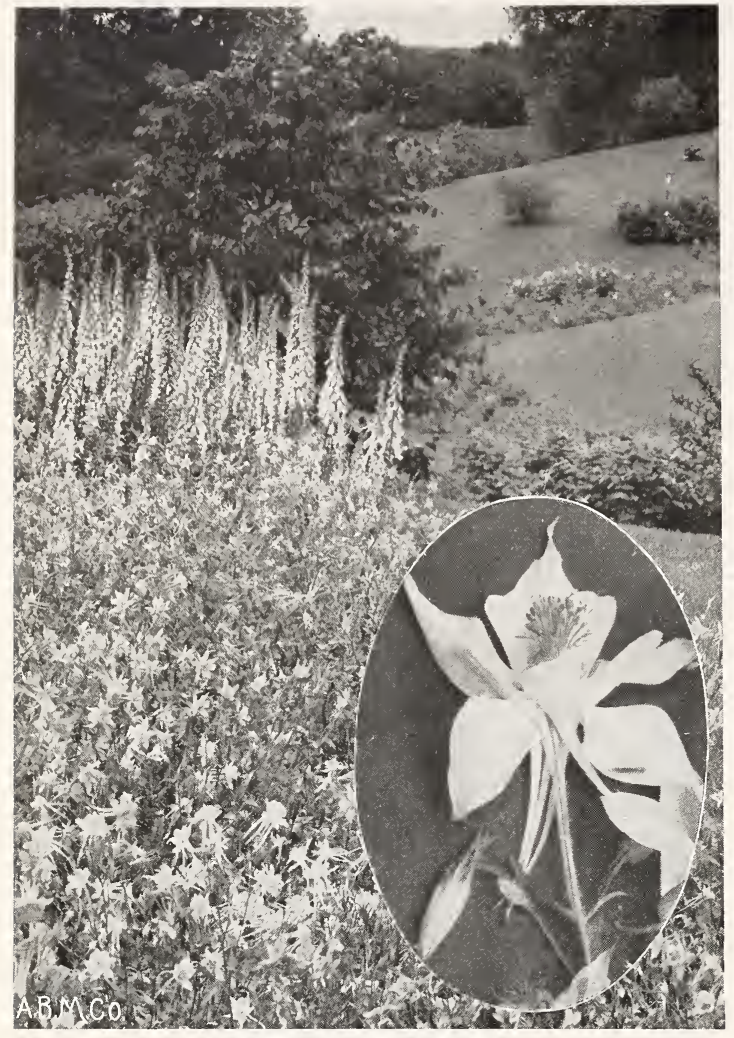

Aquilegia and Digitalis.

AGROSTEMMA. Free blooming plants of easy culture.

Coeli-rosa (Rose of Heaven). Hardy annual, bright rose; 18 in. …............

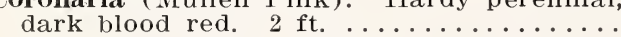

ALYSSUM. Hardy annuals much used for edging; the dwarf sorts are excellent for pots.

Maritimum (Sweet Alyssum). White, 1 foot oz., 30c. Very dwarf o oz $75 c_{\ldots} \ldots \ldots$ Saxatile Compactum. Yellow, perennial...

AMARANTHUS. Strong growing ornamental annual.

Bicolor Ruber. Scarlet and orange foliage. Caudatus (Love. Lies Bleeding). Dark red. Tricolor (Joseph's Coat). Variegated crim-

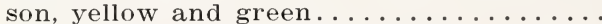

AMMOBIUM Alatum Grandiflorum. A beau-

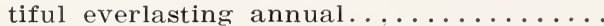

A N EMO N E Coronaria (Wind Flower). Spring flowering perennial..........

INTIRRHINUM (Snap Dragon). Half hardy perennial treated as an annual. One of the finest flowers for cutting; spikes long, gorgeously colored. Seed sown in February or March will bloom from July until frost. May also be sown in open ground in April for blooming in August.

Majus Grandiflora. Tall growing ( 3 feet). Queen Victoria. Pure white. $1 / 8 \mathrm{oz}, 25 \mathrm{c}$.

Silver Pink. Delicate rosy pink, seemingly covered with a silver sheen. $1 / 8$ oz. $25 \mathrm{c}$.

Venus. Bright rose, white throat. $1 / 8$ oz., $25 \mathrm{c}$ Firefly. Scarlet. .........

Yellow. $1 / 8$ oz., $25 \mathrm{c} \ldots \ldots \ldots \ldots \ldots \ldots \ldots$

Majus Grandiflora, Mixed. $1 / 4$ oz., $25 \mathrm{c} . \ldots \ldots$

Tom Thumb. Dwarf varieties ( $1 / 2$ foot).

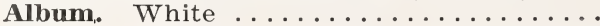

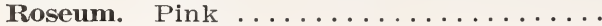

Tom Thumb Mixed.......... $1 / 8$ oz., $25 \mathrm{c}$
Pkt.

$\$ 0.05$

.05

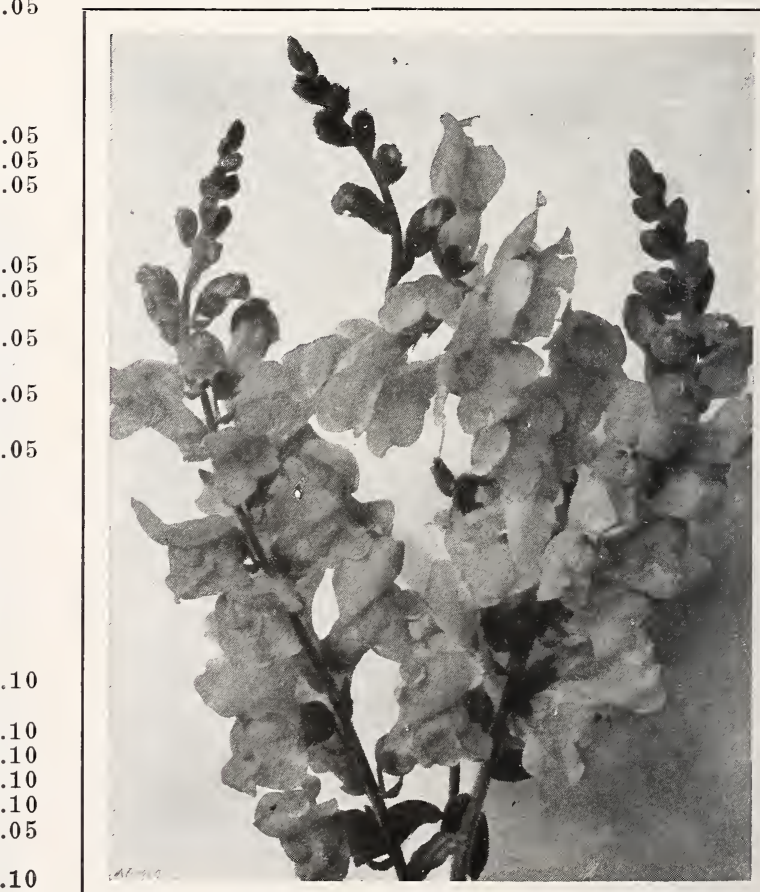

Antirrhinum. borders; withstands heat and drought re-

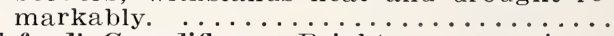

Erfordi Grandiflora. Bright rosy carmine..

BROWALLIA Elata. Mixed. Excellent for cutting; colors white and pale blue.....
Pkt.

INCHUSI Capensis. Very attractive and excellent for cutting; purple flowers. . . . . \$0.05

AQULLEGIA (Columbine). Free blooming hardy perennials; thrive best in a moist situation.

Single Mixed

Double Mixed

Chrysantha Grandiflora Hvbrida. Long spurred choice mixture ...............

ARMEIRIA Formosa (Sea Pink). Hardy per-

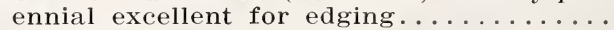

ARCTOTIS Grandis. Hardy annual. Daisylike, pure white flowers with light blue

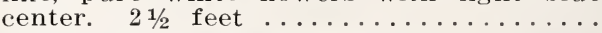

ISPARAGUS Sprengeri. Excellent for hanging baskets; 100 seeds, $50 \mathrm{c} . \therefore \ldots \ldots \ldots$.

Plumosus Nanus. Fine feathery foliage, very attractive for pot plants. 100 seeds, $\$ 1.00$..

ASPERULI. Adapted to border or rockwork; sweet scented, long bloomers.

Setosa Azurea. Light blue. 1 foot........

Odorata (Woodruff). White, $1 \frac{1 / 2}{2}$ feet.....

BALSAM. Very popular annuals, producing a brilliant array of colors. Sow in open ground in May and transplant two or three times to insure best results.

Improved Camellia Flowered. Pure white.. Mixed colors, $1 / 4$ oz., $25 \mathrm{c} . \ldots \ldots \ldots \ldots \ldots$

BALLOON VINE. A very rapid growing climber, producing curious shaped capsules; oz., 15c. ..................

BARTONIA Aurea. Beautiful annuals, flowers golden yellow and very fragrant in the

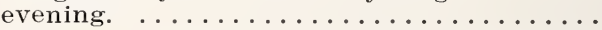

BEGONIA. Excellent for summer and autumn blooming; both flowers and foliage have a bright, waxy appearance.

Tuberous Rooted. Single mixed; superb strain

Vernon. A beautiful plant for beds and

.


BELLIS PERENNIS (Double Daisy). Highly prized perennials for borders and edging.

Longfellow. Rose color, large flowering...\$0.10

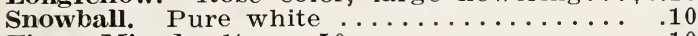

Finest Mixed. $1 / 8$ oz., $50 \mathrm{c} . \ldots \ldots \ldots \ldots \ldots . . \ldots . . . .10$

CALENDULA (Pot Marigold). Very robust. Free flowering annuals, excellent for pots or bedding.

Meteor. Double, light orange striped. $1 \frac{1}{2}$

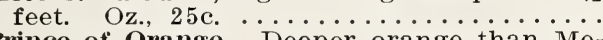

Prince of Orange. Deeper orange than Me-

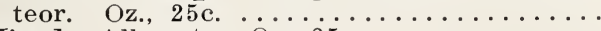

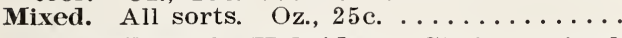

CALCEOLARIA Hybrida. Choice mixed. Recommended for greenhouse plants, with beautiful striped, blotched and variegated flower.

CAMPANULA (Canterbury Bells). Very attractive, hardy biennials, showy for borders.

Media. Single Mixed. $1 / 4$ oz., 25c.......

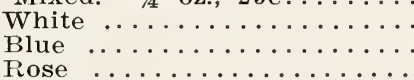
Striped

Calycanthema Mixed. Cup and Saucer. $1 / 8$

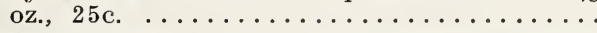

CALLIOPSIS. Very free flowering annuals, producing a gorgeous display in various shades of yellow and brown. Excellent for cutting.

Drummondii. Yellow, maroon center .....

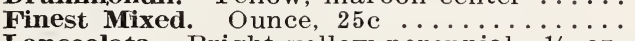

Lanceolata. Bright yellow perennial. $1 / 4 \quad \ldots z$.

CANNA. Very showy foliage and brilliant flowering plants, desirable for large beds.

Crozy's Large Flowering Dwarf. Mixed.

Dark Leaved. Mixed. . . . . . . . . . . .

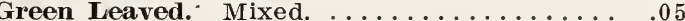

\section{Carnations}

Excellent for pots and open border culture.

Marguerite. This variety blooms in four months from sowing of seed; flowers large and fragrant. Finest mixed, $1 / 8$ oz., $30 \mathrm{c} \ldots \$ 0.10$

Marguerite. Pure white, rose or crimson,

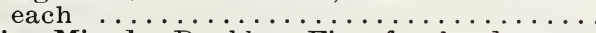

Fine Mixed. Double. Fine for borders....

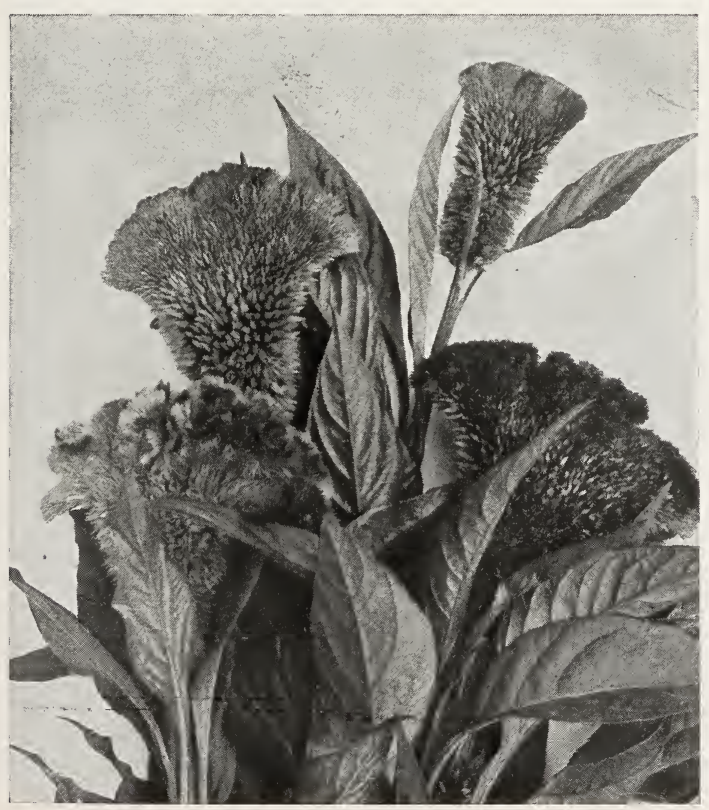

Celosia.

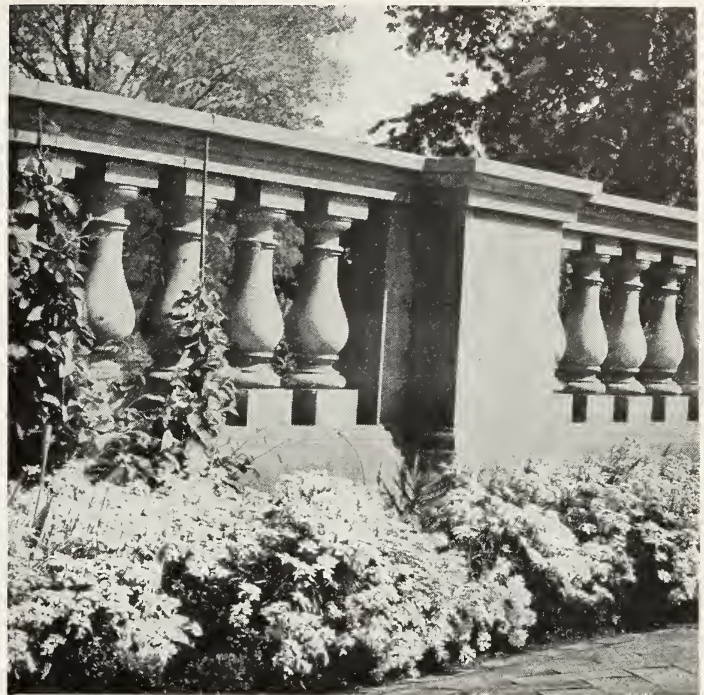

Candytuft.

\section{Candytuft}

Free flowering, showy annuals, excellent for borders and valuable for cutting. $\mathrm{Oz}$. Pkt. Empress, Large flowering, pure white. $\$ 0.40 \quad \$ 0.05$ White Rocket. A standard white sort. $.20 \quad .05$ Purple. Fine dark purple.......... $.30 \quad .05$ Crimson. Very beautiful ............. $.30 \quad .05$ Mixed. Annual varieties ....................... .050 Hardy Perennial (Sempervirens). Pure

\section{Celosia - Cockscomb}

Very showy annuals of two distinct classes. Cristata the comb varieties; Plumosa, the feather sorts.

Cristata Nana. Dwarf sorts in variety of colors. Mixed. 1/8 oz., 30c. ........\$0.10 Jristata Glasgow Prize. Dark foliage and

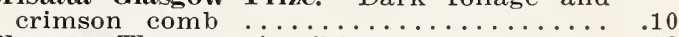
Plumosa Thompsoni. Crimson large......... .10 Plumosa Thompsoni. Yellow plumes, fine... .10 Plumosa Thompsoni. Mixed colors. $1 / 8 \mathrm{oz}$., $25 \mathrm{c} . \ldots \ldots \ldots \ldots \ldots \ldots \ldots \ldots \ldots \ldots \ldots \ldots \ldots \ldots \ldots$

\section{Centaurea}

Gymnocarpa. Silver foliage; drooping habit Imperialis. The largest flowering variety,

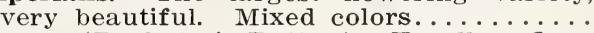
Cyanus (Bachelor's Button). Excellent flowering annual. Mixed. Oz.,25c. .........

Cyanus, Blue. Oz., 25c.

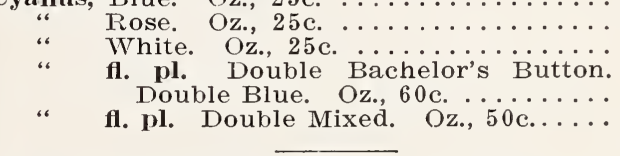

CHRYSANTHEMUMS. Very showy annuals; valuable for cutting

Single Mixed. Annual sorts. Oz., 30c. .... .05

Double Mixed. Annual sorts............ . . . . .

CINERARIA. One of the most beautiful green-house plants.

Grandiflora Mixed. Large flowering vari-

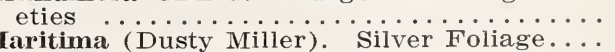

CLARKIA Mixed. Free flowering annuals of easy culture

CLEOME GIGANTEA (Giant Spider Flower). Very attractive among shrubbery. Height
3 feet. . . . . . . . . . . . . . . . .05 .10 .05 .05 .05 .05 .05 


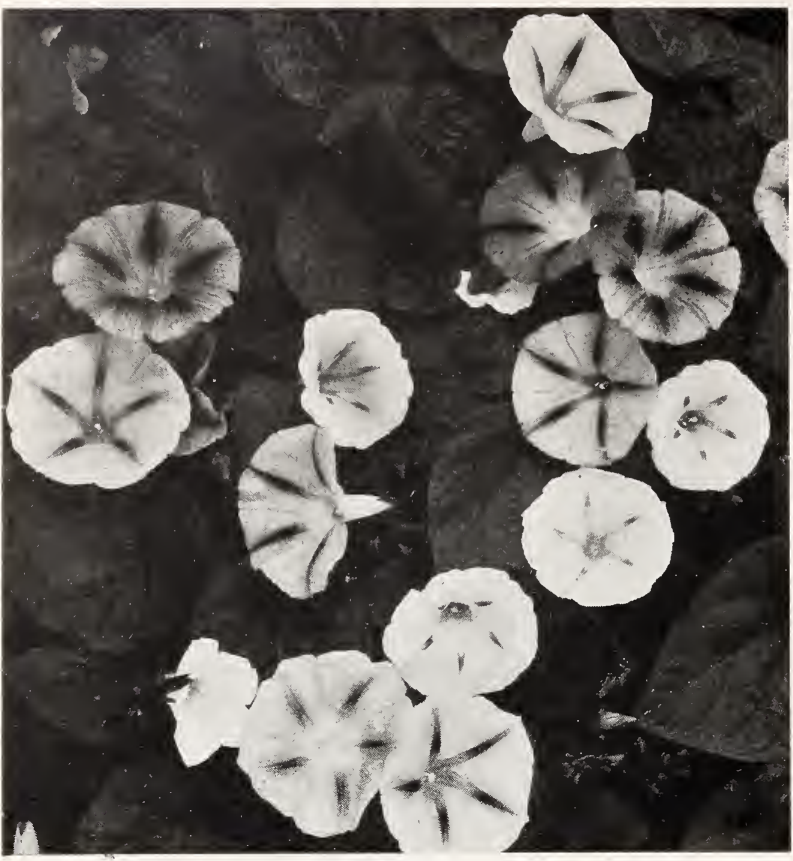

Convolvulus-Morning Glories.

COBAEA. Rapid growing climbing vines.

Scandens. Blue. $1 / 4$ oz., $25 \mathrm{c} . \ldots \ldots \ldots \ldots \ldots \ldots 0.10$

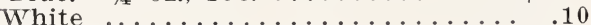

COLEUS. Ornamental foliage plants.

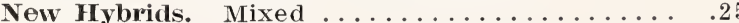

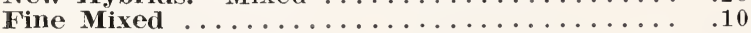

CONVOLVULUS (Morning Glories). Free flowering annuals for trellis, rockwork, etc.

Major Mixed. Quick growing climbers. Oz., 15c

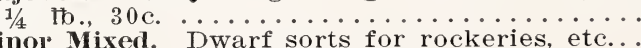

Minol Mixed. Dwarf sorts for rockeries, etc..

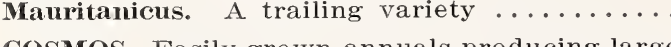

COSMOS. Easily grown annuals producing large disc-like flowers resembling Single Dahlias.

Early Flowering Mammoth. Sown in April or May, blooms from August until frost.

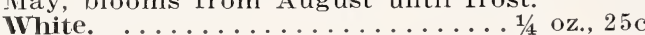
Rose. $\ldots \ldots \ldots \ldots \ldots \ldots$ oz., $25 \mathrm{c}$ Crimson. $\ldots \ldots \ldots \ldots \ldots \ldots \ldots \ldots \ldots \ldots \ldots \ldots \ldots$ oz., $25 \mathrm{c}$ Fimest Mixed. ............1/4 oz., $25 \mathrm{c}$

Mammoth Perfection. Flowers are of large size, often 5 inches in diameter.

White

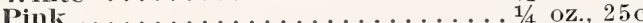
Mixed ...............1/4 oz., $25 \mathrm{c}$ Giant Lady Lenox. Rosy pink.....1/8 oz., $25 \mathrm{c}$ Pure white ...1/8 oz., $25 \mathrm{c}$

COWSLIP (Primula Veris). Hardy perennial,

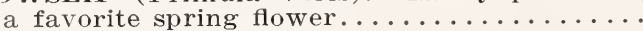

CUPHEA PLATYCENTRA (Cigar Plant). Very desirable plant for pots or borders.

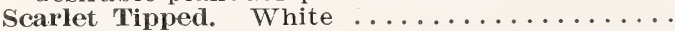

CYCLAMEN Persicum Giganteum. Excellent for pot plants; foliage is very beautiful and flowers are borne erect well above the foliage.

White, Red, Rose, White with Claret Base and

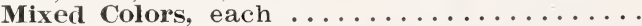

CYPRESS VINE. Climbing annual of great beauty; foliage is extremely attractive.

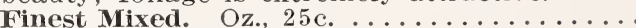

CYPERUS Alternifolius (Umbrella Plant). A very desirable plant for table decoration.....

DAISY Shasta. Hardy perennial, blooming abundantly the first year from seed. Flowers

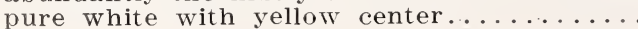

DATURA. Mixed. Hardy annuals producing large showy plants, with handsome trumpet-shaped flowers..\$0.05

DAHLIA. Half hardy perennials of value for cutting. Will bloom first season from seed sown in March or April.

Cactus. Double flowering Mixed ..... 10

Double. Large flowering mixed ..... . .10

Single. Large flowering mixed ...... .10

DELPHINIUM. Hardy perennials of value for planting in borders.

Formosum. Dark blue. ............. 10

Formosum. Light blue ...........10

Hybridum. Mixed. Large flowering sort ....

DOLICHOS LABLAB. Mixed. (Hyacinth Bean). Climbers. ...........

\section{Dianthus}

Excellent plants for beds and borders Flowers cover a wide range of colors and are very fragrant.

Chinensis. Fine mixed. (China Pink) Double flowering popular sort. $1 / 4$ oz., 15 c. ..................\$ $\$ 0.05$

Heddewigi fl. pl. Double Flowering Japan Pinks ..................... 05

Heddewigi. Single mixed. Splendid large flowering variety...........

Plumarius. Double flowering hardy garden or June Pink............ Diadematus. Double flowering Diadem

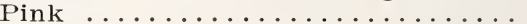

Pkt.

DIGITALIS. Desirable plants for backgrounds, borders and among shrubbery. Gloxiniaeflora. Mixed. Handsome, spotted flowers. $1 / 4$ oz., $35 \mathrm{c} . \ldots \ldots \ldots \ldots \ldots \ldots$

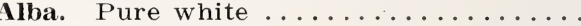

Rosea. Rose color .............................. Dew hybrids of African Orange Daisy.

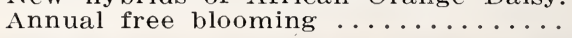

.05 .05

10

.10
.10
.10
.05

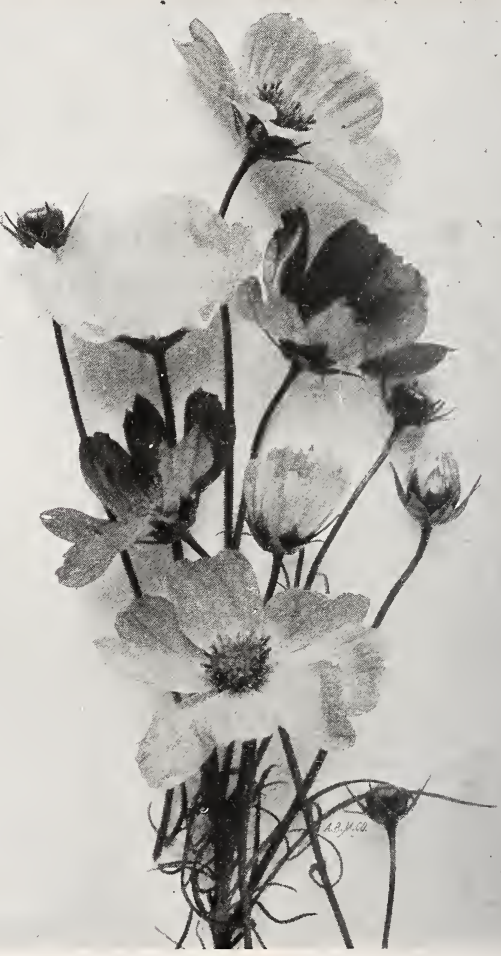

Cosmos. 
DRACAENA Indivisa. Decorative plant with long narrow green leares ..............\$0.0

ECHINOCYSTIS Lobata (Wild Cucumber). A very rapid growing annual climber..........

ESCHSCHOLTZIA (California Poppy). Profuse blooming hardy annuals bearing Poppy-like blooms from June until frost.

Californica. Bright yellow, orange center. Oz., $25 \mathrm{c}$

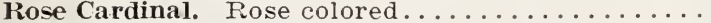
Camine King. Rosy-crimson...

ECPHORBIA. Tery pretty quick growing annuals Variegata. White and green foliage.

Heterophila. (Mexican Fire Plant).

GAILLARDIA. Showy free bloomers, excellent for bouquets.

Lorenziana Mixed. Superb annual sort. 1/4 oz., $20 \mathrm{c}$. Grandiflora. IIixed. Perennials of great beauty.

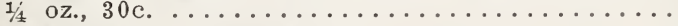

GERANIUM. Finest Mixed. .

GECM Atrosanguineum. Handsome plants for shrubbery borders. Hardy perennial.

GLOXINIA Erecta. Mixed. Splendid pot plants. GLOBE AMAR.NTHUS. Mixed. Showy ever-

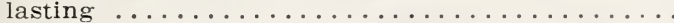

GODETIA. Free flowering annuals for beds and borders. Oz., $30 \mathrm{c}$.

GOCRDS, Ormamental. Rapid growing climbers with odd-shaped fruits. Small sorts. mixed, oz., 30c.

Gourd, Dipper, or Calabash . . . . . . . . . Gourd, Egg-Shaped. White. .

GIREILLEA Robnsta. Graceful decorative plant. GYPSOPHILA. Fine for bouquets. Free blooming. Paniculata. Perennial; fine feathery white flowers. $1 / 4$ oze, $25 \mathrm{c}$.

Elegans Grandiflora ilba. Large flowering pure white: hardy annual. Oz., $25 \mathrm{c} \ldots \ldots \ldots \ldots \ldots \ldots$

Muralis. Annual; pink bloom. .

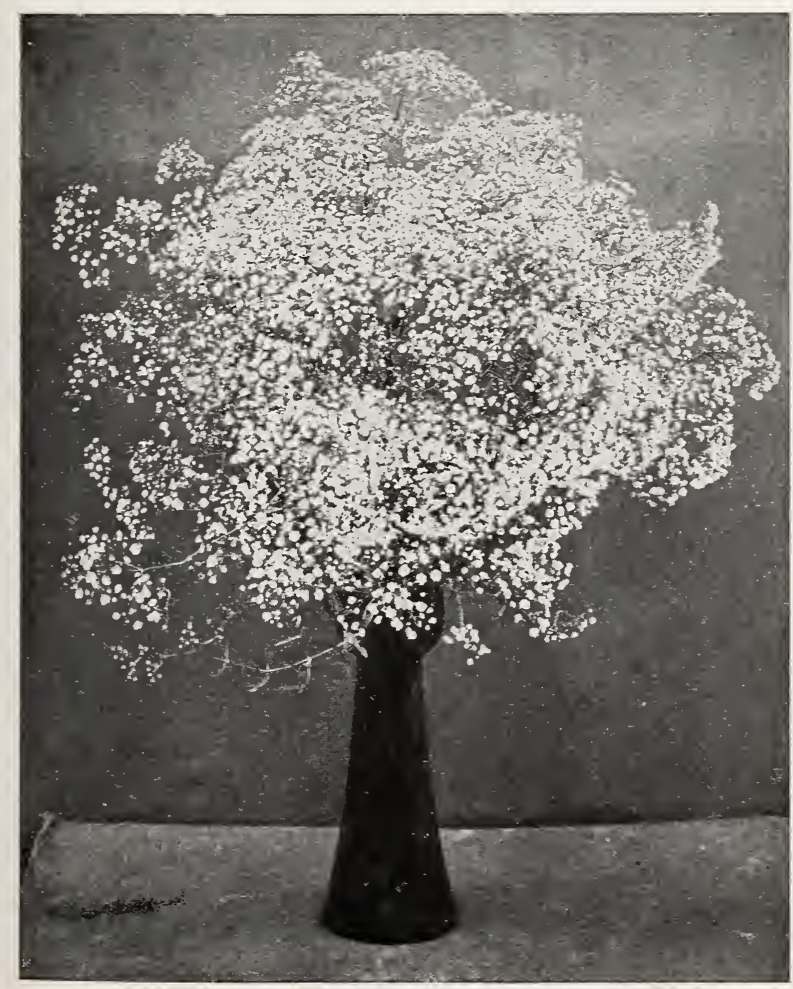

Gypsophila.
Pkt.

.05

HELIOTROPE. Finest mixed. Popular for pots or bedding.........\$0.10

HCMULCS. Quick growing annual climbers for covering arbors, etc., the first season from seed.

Japonicus. Green foliage. Oz., $30 \mathrm{c}$. Japonicus Variegatis. Variegated green and white

HELICHRYSUM. Mixed. Valuable

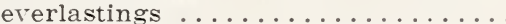

HOLLYHOCK. Very ornamental perennials, attractive in mixed borders.

Chater's Prize. Crimson, yellow, pure white, magenta, pink, salmon and mixed. each .....................

Hollyhock Annual. Flowers the fir Narch and will bloom in July or August.

Single Annual Mixed. All colors Double Annual Mixed. All colors. $1 / 4$ oz., $25 \mathrm{c} . \ldots \ldots \ldots \ldots \ldots \ldots \ldots$

HONESTY. Hardy biennial treated as an annual. Admired for its silvery seed pouches

HELIANTHUS (Sunflower). Hardy annuals; flowers rery attractive.

Anneus Purpurea (Red Sunflower) Some flowers Chestnut red, others tipped yellow, others slightly washed with red. 4 to $8 \mathrm{ft}$. . . ........

Californicus. Large, double, orange

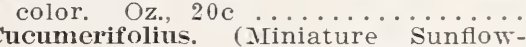
er). Single flowering; height 3 feet.

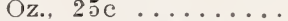

Globosus Fistulosus. Double globe shaped; height 6 feet........... Nanus fl. pl. Dwarf, double flowering. ICE PLANT. Trailing plants for rockeries, baskets, etc.
.05 


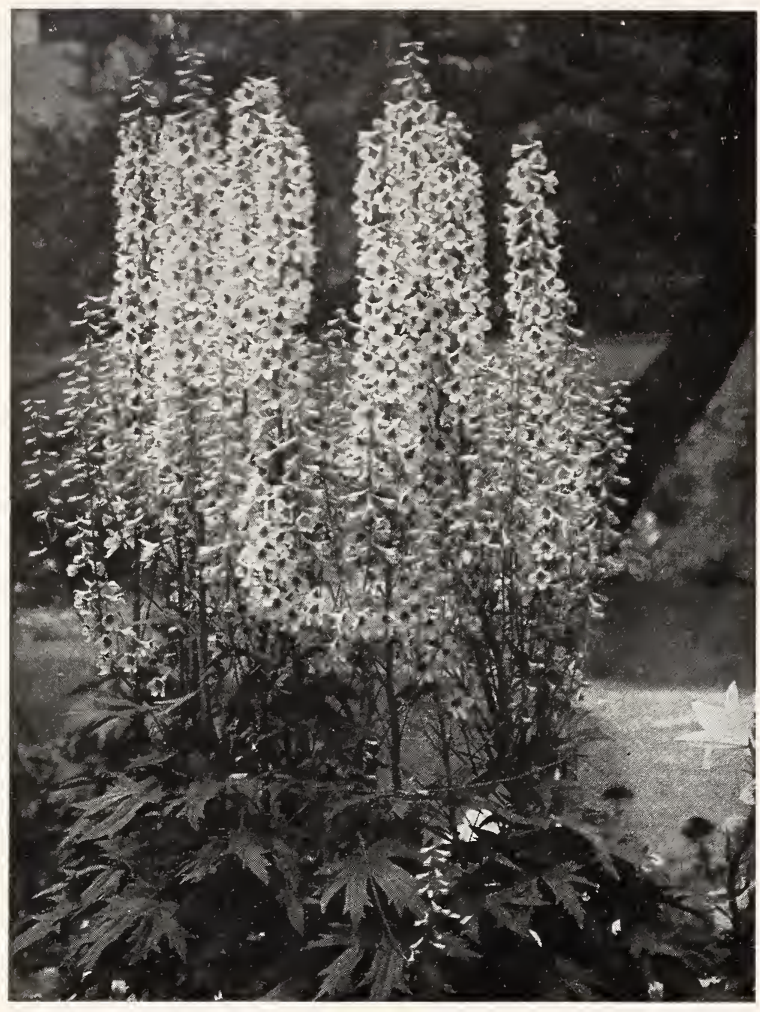

Larkspur.

IMPATIENS SULTANI (Sultan's Balsam), Beautiful decorative plants.........\$0.10

IPOMEA Grandiflora (Moonflower). Rapid growing climbers with large white flowers

Imperial Japanese Morning Glory. Very attractive blooms, rapid climbers. Oz., $25 \mathrm{c}$.

KOCHIA Tricophylla (Summer Cypress). An easily grown annual, $3 \mathrm{ft}$. high. Makes an excellent hedge or fine specimen. $1 / 4$ oz., $25 \mathrm{c}$

LANTANA Hybrida. Mixed. Rapid growing

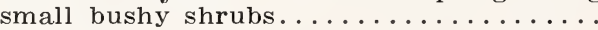

LARKSPUR. Excellent annuals for garden. Dwarf Rocket. Mixed. Oz., $25 \mathrm{c} . . . \ldots \ldots$. Tall Stock Flowered. Mixed. Oz., $25 \mathrm{c} \ldots . .25$ $\begin{array}{llll}\text { Dark blue. } 1 / 4 & \text { oz., } & 25 \mathrm{c} \\ \text { Dark rose. } 1 / 4 \text { oz., } 25 \mathrm{c}\end{array}$ Flesh color. $1 / 4$ oz., $25 \mathrm{c}$ Light blue. $1 / 4$ oz., $25 \mathrm{c}$ White. ....1/4 oz., $25 \mathrm{c}$

IATHYRUS Latifolius. Mixed. (Perennial Pea). Climbers. Oz., 50c...........

LINUM. (Flax). Annuals of graceful habit.

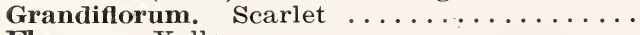

Flavum. Yellow $\ldots \ldots \ldots \ldots \ldots \ldots \ldots \ldots \ldots$
LOBELIA. Graceful plants for vases, edgings, Gracilis. Trailing sort. Light blue........

Emperor William Compacta. Light blue...

LINARIA Cymballaria (Kenilworth Ivy).

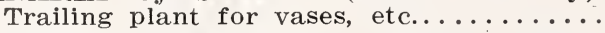

LYCHNIS Chalcedonica (London Pride). Bright scarlet, 2 to 3 feet high. Hardy

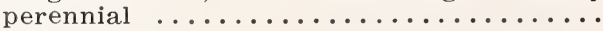

MALOPE (Mallow). Free blooming annuals, with large showy flowers. 3 feet.

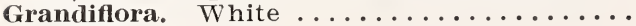

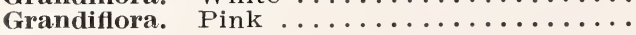

\section{.05}

.05

.05

.05

.05

.05

.05

.05

.05

.05

.05

.05

.05

.05

\section{Marigold}

Well known garden annuals. Pkt

African Tall. Mixed........1/2 oz., 15c.\$0.05

African Dwarf. Mixed.........1/2 oz., 15c .05

El Dorado. Very large, double, goldenyellow. ........1/2 0z, 20c .05

French Dwarf. Mixed. A very beautiful type. ............. 1/2 oz., $15 \mathrm{c}$

French Dwarf, Gold Striped. Brown and golden yellow ..........1/4 oz., 15c .05

French Tall. Mixed. ............1/2 oz., $15 \mathrm{c} \quad 05$ Legion of Honor. Golden yellow, with purple. .............1/2 Oz., 15c .05

\section{Mignonette}

Well known sweet scented annuals.

Grandiflora. Large flowering. . . . Oz., 15c .05

Machet. Best for pots.......1/4 oz., 25c .10

Allen's Defiance. Large spikes. 1/4 0z., 25c .10

Miles Spiral. Long spikes ............ .05

MARVEL OF PERU. (Four O'Clock). Favorite old-fashinned flowers. Oz., 15c

MAURANDIA. Mixed trailing plants for baskets

MATRICARIA Capensis. Neat, small, double white flowers .............

MIMULUS Moschatus (Musk Plant). Yel-

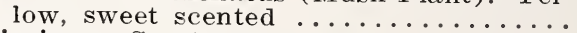

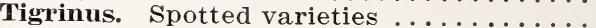

MIMOSA Pudica (Sensitive Plant).......

MOMORDICA. Very attractive for trailing on fences, stumps, etc.

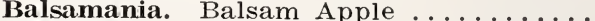

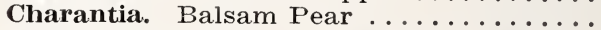

MUSA ENSETE. (Abyssinian Banana). Beautiful sub-tropical plant..........

MYOSOTIS (Forget-Me-Not). Charming perennials, producing small blue flowers. Alpestris Victoria. Stout bushy habit...... Palustris. Blue with white eye ...........

NEMESIA Strumosa Suttoni. Hardy annual. A fine plant for small beds; leaves whorled terminal racemes white and purplish tint-

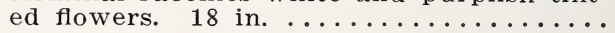

NEMOPHILA. Mixed. Pretty annuals adapted to garden culture.......1/2 oz., $15 \mathrm{c}$

NICOTIANA Affinis. A species of tobacco,

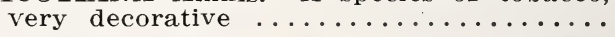

NIGELLA. Mixed. Easily grown annuals..

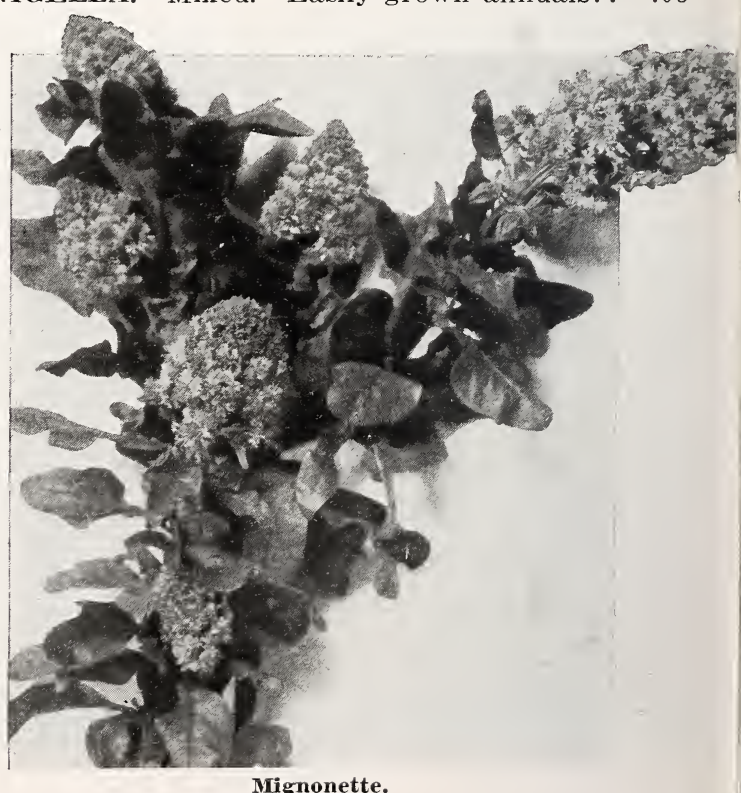

Mignonette. 


\section{Nasturtiums}

\section{Dwarf}

For summer flower beds nothing can surpass them; plants form perfect mounds about one foot high by one foot across. Seed sown in open ground early in spring produces blooming plants in early summer and continues until frost.

Iurora. Salmon and pink ......\$ Oz. $\begin{gathered}\text { Pkt. } \\ \$ 0.05\end{gathered}$

Beauty, Yellow striped red ..........20 .205

Chameleon. Variable ............ .20 .05

Cloth of Gold. Scarlet......... .20 .05

Crystal Palace Gem. Sulphur spotted

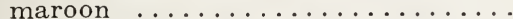

Empress of India. Crimson dark leaves Golden King. Golden Yellow........ King of Tom Thumb. Scarlet......... .

King Theodore. Dark maroon..............

Lady Bird. Orange red, spotted........ 20

Pearl. Creamy white...............20

Prince Henry. Light yellow........ . .20

Ruby King. Rose shaded........... .20

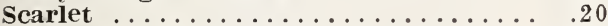

Spotted. Red and yellow........... $\quad .20$

Vesuvius. Salmon rose.............. Queen of Tom Thumbs. Mixed, varie-

Mixed. Extra quality, our own mixture, from named varieties....1/4 tb., $50 \mathrm{c}$

\section{Nasturtiums Tall or Climbing}

For covering trellis, fences, rockeries, etc., or trailing from vases, they are unexcelled; of easy culture and rapid growth, 12 to 15 feet high.

Scarlet ....... Oz.

$\begin{array}{ll}\$ 0.15 & \$ 0.05\end{array}$

Chocolate .................. $\quad .05$

King Theodore. Maroon........... .15 .05

Yellow .................. . . . 05

Hemisphericum. Yellow blotched pink. $.15 \quad .05$

Jupiter. Giant flowering, yellow..... .15 .05

Regelianum. Purple violet.............. $.15 \quad .05$

Pearl. Creamy white.............. .15 .05

Prince Henry. Cream, spotted and tip-

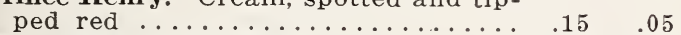

Vesuvius. Salmon rose ........... .05

Von Moltke. Ruby rose ............. .15

Mixed. Extra quality. Our own mixture from named varieties. $1 / 4$ tb., $30 \mathrm{c} \quad .10 \quad .05$

\section{Pansies}

Seed should be sown in July and August for early spring blooming, or if sown in May will make excellent plants for late summer and fall blooming.

Pino's Special Mixture. In this mixture we offer all the choice fancy sorts, and we believe nothing better can be procured. $1 / 4$

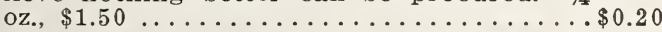

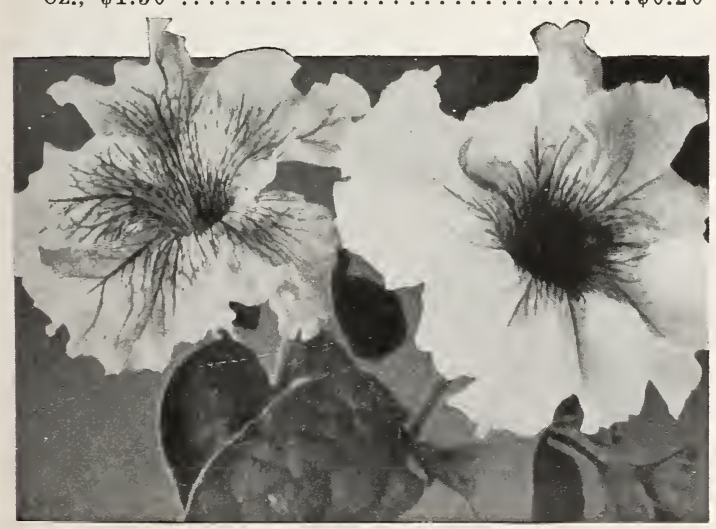

Petunias.

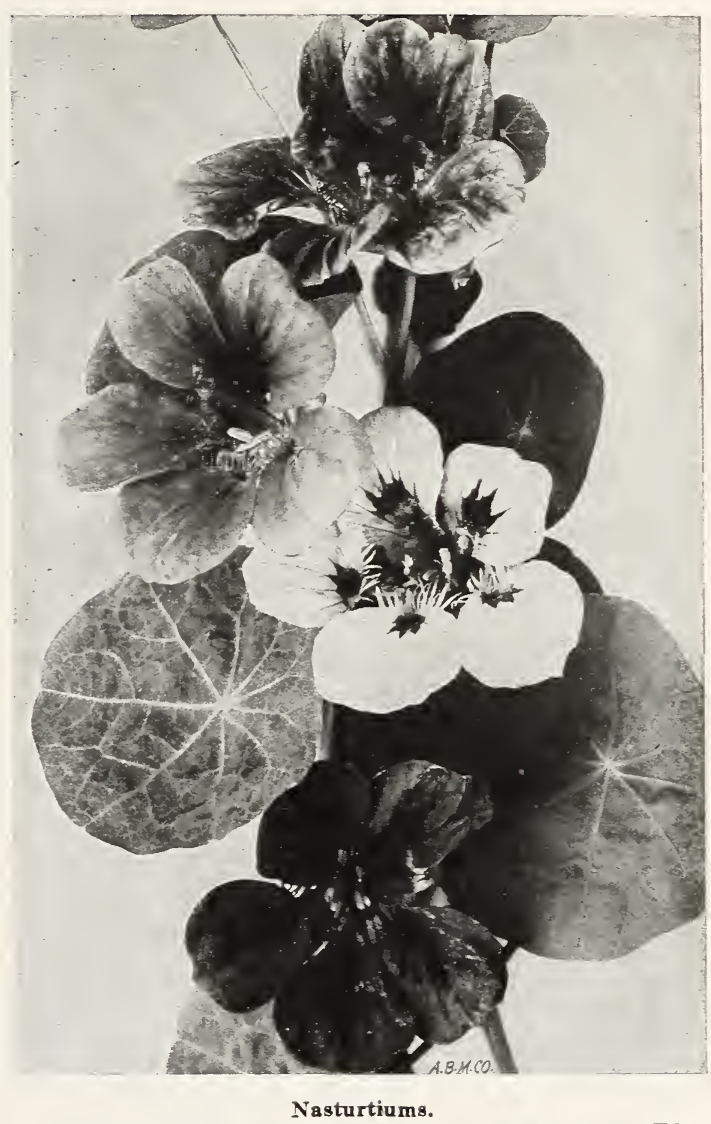

English Show. Large flowering English sorts .................. \$0.20

Bugnot's Stained. Superb blotched varieties .20

Cassier's Giants. Splendid large flowering

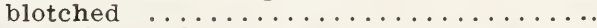

Masterpiece. Curled, wavy petals, new and

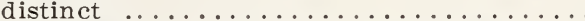

Orchidaeflora. A large flowering class, comprising many new and novel shades......

Very Fine mixed. Splendid varieties. $1 / 4 \mathrm{oz}$, Good Mixed. "Fine bedding varieties $1 / 4$ oz.. $50 \mathrm{c} \ldots \ldots \ldots \ldots \ldots \ldots \ldots \ldots \ldots \ldots \ldots \ldots \ldots \ldots \ldots \ldots \ldots \ldots \ldots$

Trimardeau Giant. The largest and most robust in growth. Pkt.

White $\ldots \ldots \ldots \ldots \$ 0.15$ Striped ......\$0.15

Yellow ...................... Lord Beaconsfield. .15

Purples ............. .15 Mixed. $1 / 4$ oz., $50 \mathrm{c}$. .15

Tufted Pansies. Very free blooming Pansies, adapted to shady place. Small flowering.

$1 / 4$ oz., $50 \mathrm{c} \ldots \ldots \ldots \ldots \ldots \ldots \ldots \ldots \ldots$

\section{Petunia}

General favorites of easy cultivation, blooming continuously from early summer till frost. Pkt. Fine Mixed. Single bedding sort. $1 / 4 \mathrm{Oz}, 25 \mathrm{c} . \$ 0.05$ Alba. Pure white ...........1/4 oz., $25 \mathrm{c} .05$ Countess of Ellsmere. Dark rose with white throat $\ldots \ldots \ldots \ldots \ldots \ldots \ldots \ldots \ldots \ldots . .10$ General Dodd's. Dark crimson............. 10 Striped and Blotched. Splendid varieties... $\quad .10$ Dwarf Striped and Blotched. Excellent for vases

Grandiflora. Single Mixed. Choice large flowalifornia Ruffed Giants. Extremely lärge California Ruffled Giants. Extremely large
flowers with ruffled edges; exquisite colorings and markings..................

Fringed Double. Very choice sorts...........5 Double Fine Mixed ................ .25 


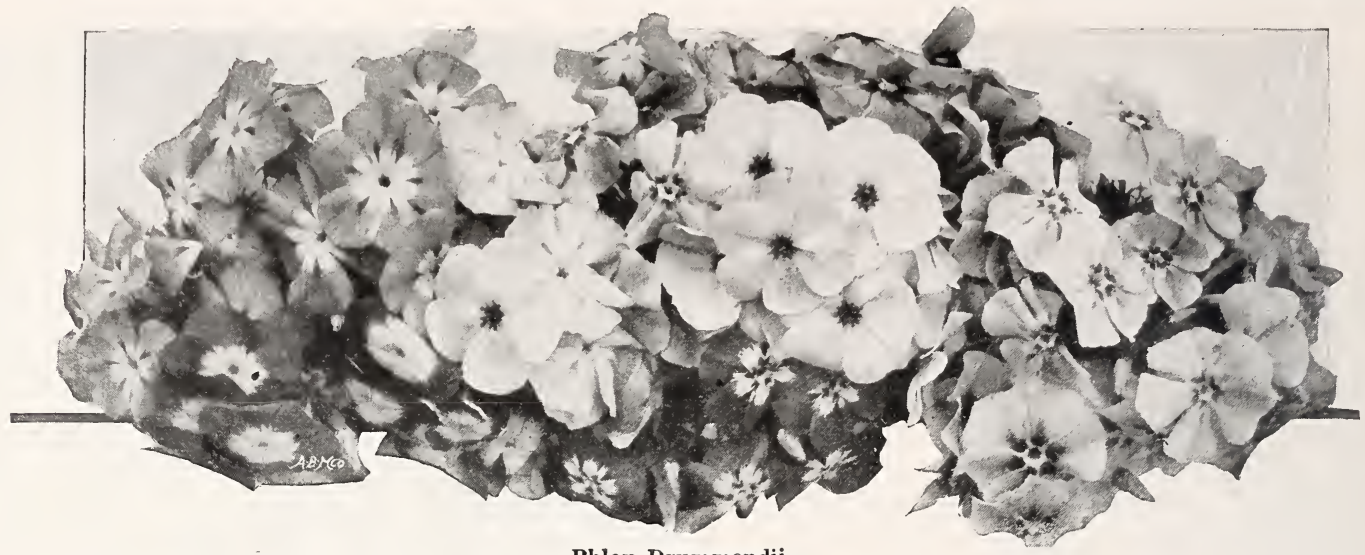

Phlox Drummondii.

\section{Phlox Drummondii}

Excellent annuals for bedding.

Grandiffora Alba. Pure white.

Coccinea. Brilliant scarlet........... .10

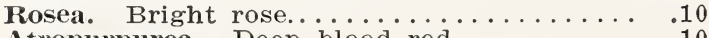

Atropurpurea. Deep blood red.............10

Grandiflora Mixed. Choice large flowering sorts …............................ $25 \mathrm{c}$

Cuspidata. Splendid star-shaped varieties...

Decussata Mixed. Perennial sorts.........

\section{Poppies}

Splendid plants for borders, beds, etc.

Carnation Flowered. Splendid double fringed varieties. Mixed ................. 25c

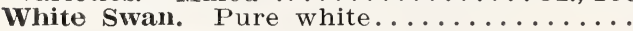

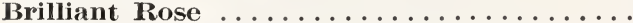

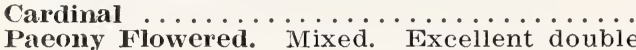
varieties

Danebrog. Brilliant scarlet with white blotch,

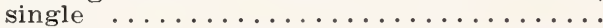
Glaucum (Tulip Poppy). Dazzling scarlet, single ......................... $50 \mathrm{c}$

Shirley. Single. Mixed. Very dainty colored, with rich satin appearance. ....... Oz., $50 \mathrm{c}$

Orientale. Enormous deep scarlet flowers. Perfectly hardy ...........1/8 oz., 25c orientale. Hybrids mixed. Hardy perennial. Finest shades ............1/8 oz., 25c

Iceland. Mixed, hardy perennial, blooming

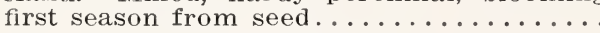

PERILLA NAUKENEUSIS. Splendid foliage

PLATYCODON Grandiflora. Hardy perennial bright red bell-shaped flowers.

POLYANTHUS. Popular hardy perennial. Finest named sorts, mixed.

PORTULACA. Very brilliant dwarf annuals, suitable for warm, dry situations. Should not be sown until hot weather.

Single. Fine mixed.................. $50 \mathrm{c}$

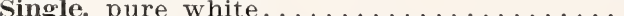

Single, golden yellow

Single, flesh

Single, scarlet

Double, choice mixed

PRIMUIa SINENSIS (Chinese Primrose). Excellent pot plants for winter decorations.

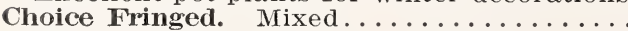

PRIMULA OBCONICA. A profuse blooming primrose with pale lilac flowers. Seeds sown early in spring produce blooming

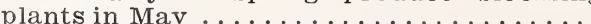

Forbesi. The Baby Primrose............

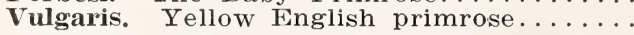

PIRETHRUM AUREUM (Golden Feather) Golden leaved plant for edging. .1/4 oz., $20 \mathrm{c}$

PYRETHRUM HYBRIDUM Grandiflorum Flowers. Large, aster-shaped, colors pink, to deep red with bright yellow centers....
RICINUS (Castor Oil Plant). Highly ornamental plants; excellent for large groups.

Borboniensis. Dark green, 15 feet; ..oz., 20c Cambodgensis. Very dark foliage and stem, 5 feet $\ldots$ Oz., $25 \mathrm{c}$ Gibsoni. Dark red, 5 feet.......... Oz., $20 \mathrm{c}$ Sanguineus. Blood red foliage, $6 \mathrm{ft}$. . Oz., $20 \mathrm{c}$ Fine Mixed ....................... $20 \mathrm{c}$

Zanzibariensis. Mixed. Very large growing sort, extremely attractive.......... Oz., $25 \mathrm{c}$

ROCKET SWEET. Hardy perennial, 2 feet high, white and purple. Mixed.........

SALVIA (Scarlet Sage). Easily grown, free flowering and extremely showy.

Splendens. Vivid scarlet, 2 feet...1/8 oz., 35c Bonfire. Early flowering, scarlet, $1 \frac{1}{2}$ feet, $1 / 8$ oz., $50 \mathrm{c} \ldots \ldots \ldots \ldots \ldots \ldots \ldots \ldots$.

Zurich. Very dwarf, early flowering......

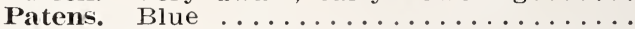

SALPIGI.OSSIS Emperor. Mixed. Improved large flowering strain. Very showy annual with funnel-shaped flowers borne on slender stems, in rich shades, beautifully penciled and veined. Free blooming, July to October ................ $1 / 8$ oz., $20 \mathrm{c}$

SCABIOSA (Mourning Eride). Showy border plants with beautiful variegated flowers.

Dwarf Mixed. $1 \frac{1 / 2}{2}$ feet . . . . . . . . . . . .

Tall Mixed. $21 / 2$ feet....

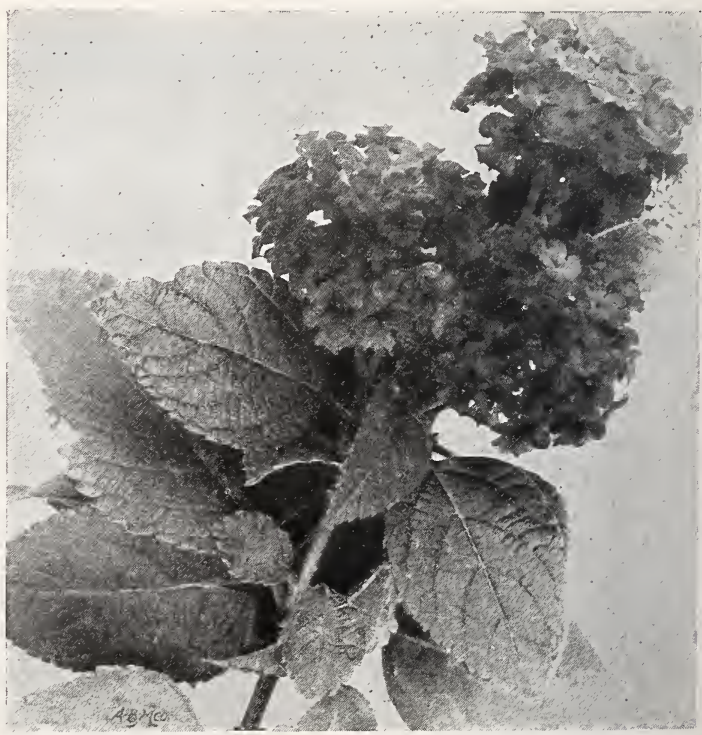

Pkt.

.05 


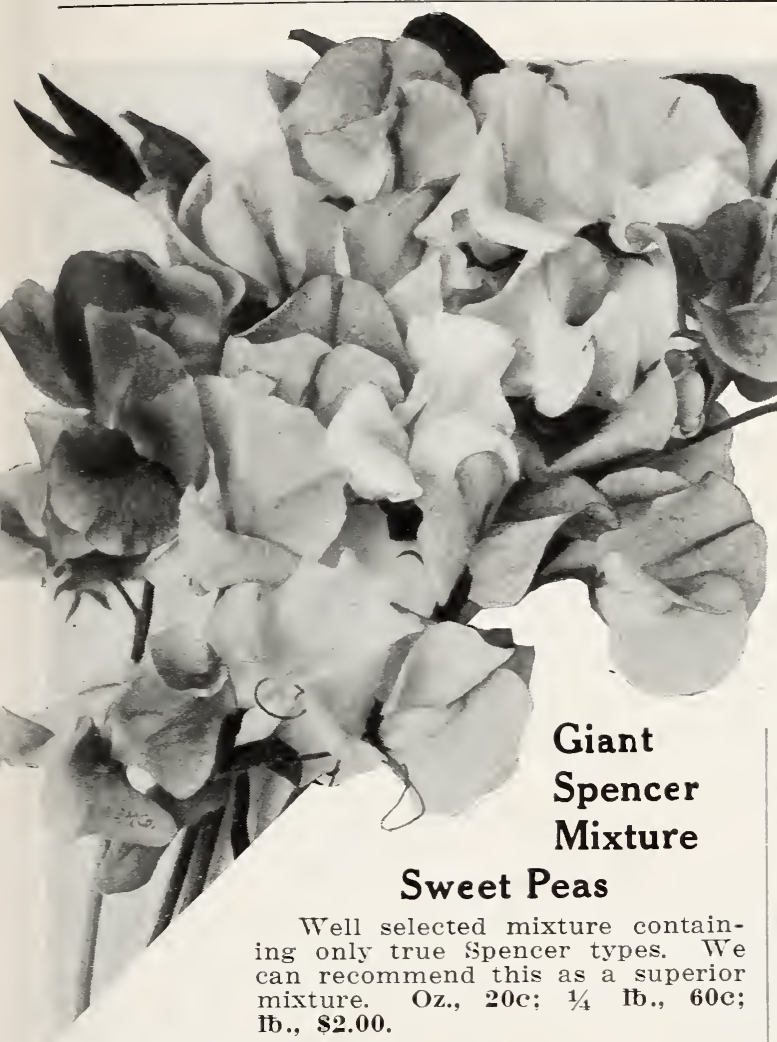

\section{Stocks, Ten Weeks}

German, Ten Weeks. Splendid for bedding or pot culture; free blooming and covering a wide range of color.

Large Flowering. Pure white, blood red, flesh color, rose, canary yellow, purple, lavender. Finest mixed, each.

Princess Alice (Cut and Come Again). Pure

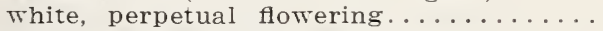
Beauty of Nice. Delicate flesh pink.

Queen Alexandra. Rosy lilac.

SCHIZANTHCS. Free blooming annuals, excellent for bedding. Finest mixed......\$0.0

SMILAX. Beautiful climber.......... .05

SOLANCM Capsicastrum. Jerusalem Cherry

THCNBERGLA. Mixed ornamental climbers

TROPAEOLCM Lobbianum. Climber, dark foliage, bright colored flowers..........

Canariensis (Canary Bird Flowers).

SIVEET WILLIM. Popular old-fashioned plants.

Dark Crimson

Pure White

Scarlet

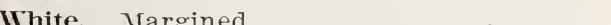

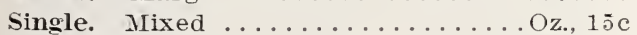

Double. Mixed ..........1/4 oz., $20 \mathrm{c}$

\section{Wild Flower Garden Mixture}

These mixed flower seeds embrace more than a hundred varieties of such easy growing and pretty flowers as are suitable for forming a wild flower garden. They are very useful for woodland walks, roadsides, alongside of fences and on untidy bare spots which, if properly cared for and kept free from weeds, can bloom during the summer. Pkt., 10 cents.

\section{Sweet Peas}

During the last ten years great improvement has been made in size and beauty of this popular flower and the development is still in progress. New colors, form and types are being brought out by the Sweet Pea growers every year, but we will confine our list here to the best tried sorts, and we feel confident that we can take care of the wants of our customers with the stock $\pi^{*}$ carry.

The proper time to spade garden for Sweet Peas is in the fall, as the longer the soil remains in the rough state the better. Give a liberal dressing of $\pi$ ell rotted stable manure, ground bone and a dusting of lime. Spade to depth of six or eight inches and allow soil to remain in the rough without chopping down. When sowing seed see that the soil is firmly tread down, as Sweet Peas require not only a deep soil but a firm one. Seed should always be sown early in spring one inch deep and when plants are well up thin to two to four inches apart. Many thin to six to nine inches apart and when three or four inches high pinch out tops to start branching. Support should be given early before plants get twisted. When hot, dry weather begins, see that the plants are well mulched and well watered. Look out for green aphis and keep clean by spraying with solution of tobacco extract. Care must be taken to keep flowers picked, as the forming of seed pods will stop blooming.

In giving a list of the Sweet Peas we have confined ourselves to those sorts that have been tested as the strongest growers, and from the various shades and colors have selected those which are the clearest and the truest.

\section{Grandiflora Varieties}

Price, oz., 10c; 1/1 to.. 30c: tb.. \$1.00.

Blanche Ferry. Rose and white.

Dorothy Eckford. Large white.

Flora Norton. Bright blue.

Katherine Tracy. Pink.

King Edward III. Bright red.

Lady Grisel Hamilton. Lavender.

Lorely. Deep, shading to light pink.

Mrs. Collier. Primrose.

Othello. Deep maroon.

Prima Donna. Pink.

Salopian. Bright red.

\section{Pino's Perfection Mixture}

A carefully prepared mixture of the finest Grandiflora varieties. Oz., 10c; 1/4 th., 30c: 1b.. \$1.00.

\section{Giant Spencer-Waved Varieties}

Spencer Sweet Peas are the largest and most beautiful of all known Sweet Peas, the individual flowers measuring frequently 2 to $2 \frac{1}{2}$ inches across: they are also remarkable for their profuseness and continuous bloom. On strong stems 9 to 12 inches long, the beautiful flowers are borne three to four on a stem. The standards are open, well rounded and exquisitely wared and ofter serrated.

Packet, 10c; oz., 30c; 1/4 1b., \$1.00.

Asta Ohn. Pinkish lavender.

Blanche Ferry Spencer. Bright rose standard,

wings white, flushed pink.

Countess of Spencer. Pure pink.

King Edward Spencer. Pure red.

Othello Spencer. Deep maroon.

Primrose Spencer. Pure primrose.

iVedgewood. Blue.

White Spencer. Pure white, select strain 


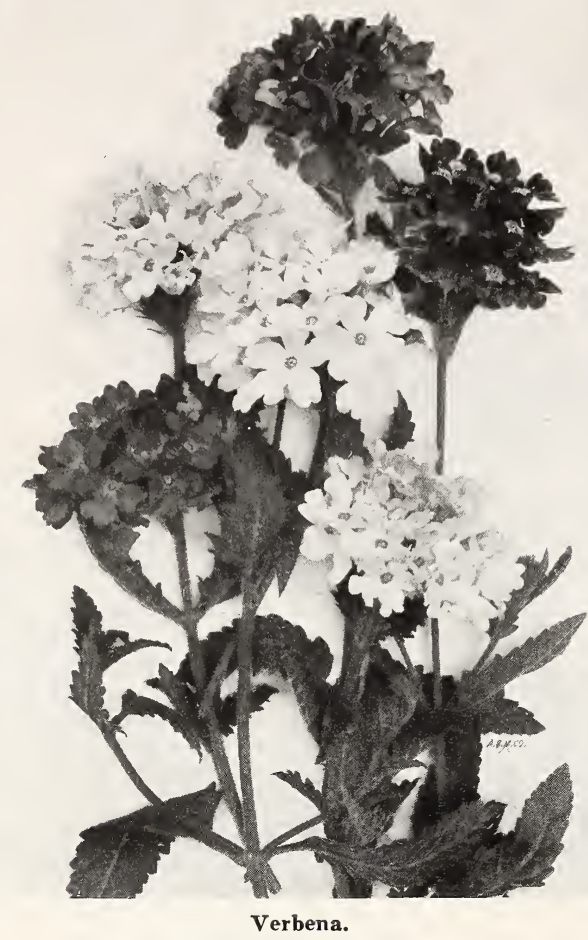

Verbena

Popular free blooming plants, excellent for garden culture.

Mammoth, White....

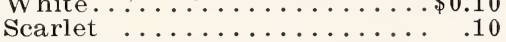

Pink shades ................ 10

Blue shades ............... 10

Mixed ............

Lemon Scented. Scented leaves.......... 10

VINCA. Fine for pots or borders.

Alba. Pure white; Rosea rose; mixed, ea. $\quad .05$

VIOLA Odorata (Sweet Violet). Fragrant

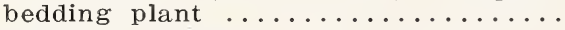

VIRGINIAN STOCK. Hardy annuals for

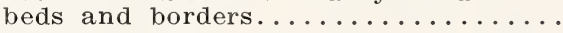

WALLFLOWER. Favorite sweet scented flower.

Earliest Paris. Flowers first season..... .10

Single Mixed

Double Mixed $\ldots \ldots \ldots \ldots \ldots \ldots \ldots \ldots \ldots \ldots \ldots . .10$

\section{Zinnia}

Robust growing annuals, very free flowering. No flowers are more easily grown from seed in the open ground, and few bloom so continuously through the entire summer. Those acquainted only with the old-time Zinnias will be surprised at the perfection to which the newer strains have attained.

Tall Double. Mixed. Height $2 \mathrm{ft}$; $1 / 4$ oz., $25 \mathrm{c} \ldots \ldots \$ 0.05$ Dwarf Double. Mixed. Height $1 \frac{1}{2} \mathrm{ft}$; $1 / 4$ oz., $25 \mathrm{c} . \ldots .05$ Double Dwarf. White, orange, purple, rose, sulphur

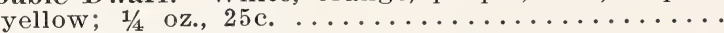

Mammoth Double. Mixed. Very large flowers covering a wide range of coloring; $1 / 4$ oz., $25 \mathrm{c} . \ldots \ldots \ldots$

Mammoth Double Scarlet. Very large and brilliant

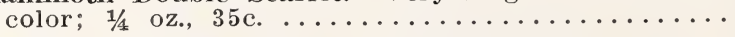

Pompon. Mixed. Dwarf, small flowering......... Curled and Crested. Petals beautifully curled and and twisted; $1 / 4$ oz., $25 \mathrm{c} \ldots \ldots \ldots \ldots \ldots \ldots \ldots \ldots$

Zebra. Striped sorts. $1 / 4$ oz., $25 \mathrm{c} . \ldots \ldots \ldots \ldots \ldots .10$

\section{Ornamental Grasses}

Pkt.

and bouquets ........................... $\$ 0.05$ Arundo Donax. Hardy perennial, sub-tropical plants; ornamental in habit............05

Avena Sterilis (Animated Oats). Hardy annual .05 riza Maxima (Quaking Grass). Hardy annual,

pretty for bouquets... Hädy perennial, fine

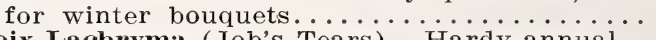

Coix Lachryma (Job's Tears). Hardy annual.. nual; very attractive; excellent for bouquets..

Erianthus Ravennae (Plume Grass). Tender

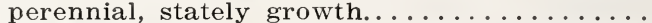
ulalia Japonica. Hardy perennial; beautiful tall growing grass....................... (Pampas perennial, bearing beautiful plumes......... Hordeum Jubatum (Squirrel Tail Grass). Hardy

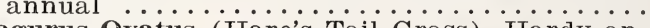

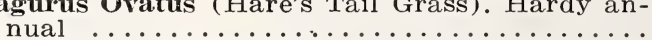
Pennisetum Longistylum, Hardy annual, very

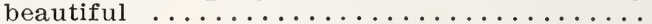
tipa Pennata (Feather Grass). Hardy peren-

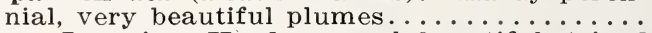

Zea. Japonica. Hardy annual, beautiful striped

\section{Bedding Plants}

We import large Quantities of Fall $B u l b s$ and handle strictly first quality.

Our Annual Bulb Catalogue will be issued September 1st. Send for it. 


\section{Summer Flowering Bulbs}

\section{Begonias, Tuberous Rooted}

Begonias are indispensable for shady places in the garden or lawn, also desirable for pots or piazza boxes. Start in the house in March or April and remove to the open ground as soon as danger of frost is past. They will bloom freely from July until cut down by the frost. Dry tubers may also be planted in the open ground in May. Care should be taken to keep constantly moist.

Single. White, yellow, rose, scarlet, crimson, orange. Price, extra fine bulbs, 10c each; $75 \mathrm{c}$ per doz.

Double. White, yellow, rose, scarlet, crimson, orange. Price, extra fine bulbs, 10c each, \$1.00 per doz.

\section{Calla Lilies}

Spotted leaved. Desirable for outdoor planting. Requires a moist situation. 10c each, \$1.00 per doz.

\section{Caladium}

Esculentum. This is one of the most beautiful and striking of the ornamental foliage plants, for growing in pots or for planting on the lawn, or masses in beds. It is of the easiest culture, and will grow in any good garden soil.

Dry Bulbs, 10c each, 75c per doz.; medium, 15c each, \$1.25 per doz.; large, 20c each, $\$ 2.00$ per doz.

Fancy Leaved. Decorative foliage plants for pots, baskets, tropical bedding, etc. 20c each; doz., \$2.00.

\section{Cannas}

10c each; 75c per dozen.

Alphonse Bouvier. Finest tall crimson.

Duke of Marlborough. Very deep crimson.

Florence Vaughn. Golden yellow, spotted crimson.

J. D. Eisle. Brilliant vermilion scarlet, overlaid with orange.

President Meyer. Rich cherry carmine.

Professor Romberge. Brilliant fiery red.

Richard Wallace. Canary yellow.

Venus. Very soft rosy pink.

West Virginia. Crimson scarlet with broad golden edge.

Shenandoah. Best dark leaved.

\section{Dahlias}

20c each; \$2.00 per dozen.

\section{CACTUS VARIETIES}

Rer. A. Bridge. Yellow tipped rose pink.

Lord Minto. Salmon pink to yellow.

Memoria Margarite. Dark maroon.

Genesta. Amber to gold.

Rev. T. W. Jameson. Yellow to lilac rose.

Libelle. Rich purple.

Flag of Truce. Pure white.

Wellington. Dark maroon, fine.

John Bright. Large crimson.

Harrold Peerman. Pure yellow.

H. L. Brusson. White center to deep rose.

\section{SHOW AND FANCY VARIETIES}

Mrs. Saunders. Yellow tip, white.

Cuban Giant. Maroon.

Emily. Lavender to white.

Lucy Faucet. Sulphur stripe, crimson.

A. D. Levone. The standard pink.

Grand Duke Alexis. White to lavender.

Fascination. Variegated white to crimson.

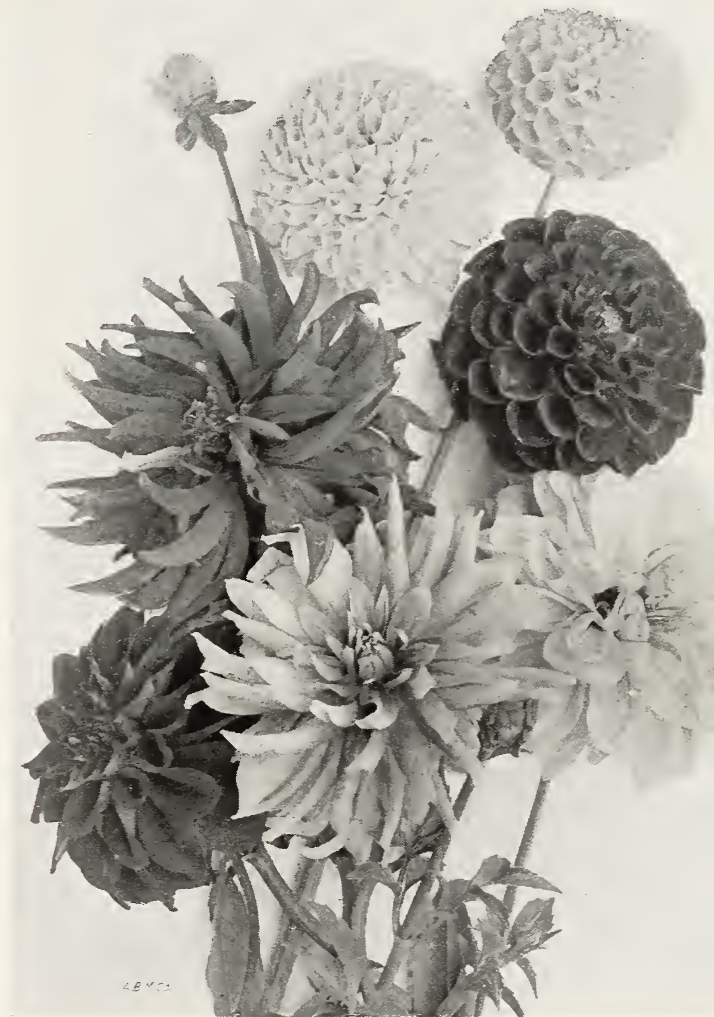

Cactus and Decorative Dahlias.

\section{DECORATIVE VARIETIES}

Calosse. Canary yellow; very large.

Delice. Best pure pink.

Jeanne Charmet. Rose pink to white.

Cream de Mint. Carmine and yellow.

Mrs. Winters. Best nure white.

Sir Rolf. Pale pink to reddish violet; fine.

La Grande Maniton. Lavender mauve stripe, violet red, large, beautiful.

Jack Rose. Rose crimson.

Le Grant. Velvet red.

W. W. Rawson. White to amethyst blue.

\section{PEONY-FLOWERED}

Geisha. Orange, crimson and yellow.

Blenheim. Crimson and white, fine.

Paul Kruger. Striped red and white.

Liberty Bell. Red.

POMPONS, in variety.

SINGLE FLOWERING. In variety.

\section{Gloxinias}

Should be grown in pots in the house or on the veranda, in boxes or little frames outside, and will flower all summer. Their green leaves are surmounted with a cluster of lovely trumpet shaped flowers. The coloring is exquisite; the groundwork of many is pure white, with throats of blue, scarlet, rose or crimson; or the tubes are of bright colors with white throat. The bulbs should be started in a warm place-greenhouse, hot bed or sunny window. Farly in the fall they should be dried off, letting the leaves die; pots can be kept over winter in a cellar free from frost. Extra strong bulbs, named varieties, $10 \mathrm{c}$ each; $\$ 1.00 \mathrm{doz}$. 


\section{Gladiolus}

Bulbs planted in open ground in spring produce plants with long, rush-like foliage and magnificent flower spike early the following autumn.

America. One of the finest varieties; color soft flesh pink; orchid-like in color and texture. Doz., 40c; 100 for" \$2.50.

Annie Wigman. Pale yellow, dark blotch. Doz., $40 \mathrm{c} ; 100$ for $\$ 2.50$

Augusta. White with blue anthers. Doz., 40c; 100 for $\$ 2.50$.

Baron Hulot. Royal violet blue. Arranges beautifully in combination with the yellow sorts. Doz., 40c; 100 for $\$ 2.50$.

Brenchleyensis. One of the best vermilion scarlet sorts. Doz., 40c; 100 for $\$ 2.50$.

Czar Peter. Brownish red; very strong grower. Doz., $75 \mathrm{c} ; 100$ for $\$ 5.00$.

Electra. Soft red, extra large and very attractive. Doz., 75c: 100 for $\$ 5.00$.

Empress of India. Brownish black. One of the best dark sorts. Doz., 50c; 100 for $\$ 3.00$.

Europe. Finest white. Doz., \$1.00; 100 for $\$ \mathbf{\$ 7 . 0 0}$.

Glory of Holland. Pure white with lavender anthers. Doz., 50c; 100 for $\$ 3.00$.

Halley. Salmon pink. Doz., 40c; 100 for $\$ 2.50$.

Lily Lehman. Ivory white, without markings; extra fine. Doz., 50c; 100 for $\$ 3.00$.

Master Weitse. Light maroon ' quite distinct. Doz., 60c; 100 for $\$ 4.00$.

Mrs. Frances King. Beautiful light scarlet. Doz., $50 \mathrm{c} ; 100$ for $\$ 3.00$.

Mrs. Frank Pendleton. Salmon pink with maroon blotch on lower petals. Each, 20c; Doz., \$2.00. Niagara. Cream lower petals blending to canary, throat splashed carmine. Doz., 75c; 100, \$5.00.

Panama. Rose, extra fine spike. Doz., 50c; 100 for $\$ 3.00$.

Peace. White, interior petals feathered pale lilac, late flowering. Doz., \$1.00; 100 for \$6.00.

Pink Beauty. Violet rose dark center. Doz., 30c; 100 for $\$ 2.00$.

Pink Perfection. Beautiful pink, extra fine spike. Doz., 75̃c; 100 for $\$ 5.00$.

Princeps. Rich crimson with deep shading and blotches on lower petals. Doz, 50c: 100 for $\$ 3$.

Schwaben. Rich orange yellow with carmine blotch, extra long spike. Doz., 75c; 100 for $\$ 5$.

War. Blood red, extra large and tall grower. The best red. Doz., \$1.00; 100 for $\$ \mathbf{7 7 . 0 0}$.

White Excelsior. Pure white; late flowering. Doz., 50c; 100 for $\$ 3.00$.

Willy Wigman. Creamy white with dark red bloteh. Doz., 40c; 100 for $\$ 2.50$.

Childsii Seedlings. Mixed. Our stock of this beautiful giant Gladiolus has been greatly improved in the selection of colorings, and now contains a well-balanced mixture of all shades known to Gladiolus. Doz., 35c: 100 for $\$ 2.50$.

Pino's Special Mixture. Selected to cover a wide range of types, and we have given special attention to the selection of the lighter and more desirable shades. All bulbs strictly first size. Doz., $35 c: 100$ for $\$ 2.50$.

\section{Lilium}

Auratum (The Golden-Rayed Lily of Japan). The flowers are pure white, thickly studded with crimson spots, while through the center of each petal runs a clear golden band. Flowers measure nearly a foot across. First size bulbs 20c each: \$2.00 doz.

Album, This is a pure white and very fragrant variety, with beautifully recurved petals. A very fine sort. Each 25c; doz., \$2.50.

Rubrum. White ground, with bands and spots of rose or crimson on each petal. One of the best lilies. We have a splendid stock of this very hardy and beautiful kind. Each, 20c; doz.; $\$ 2.00$.

Tigrinum Splendens (Improved Tiger Lilv). Reddish salmon with dark spots. Each, 10c; doz., $\$ 1.00$.

Tigrinum Flore Pleno (Double Tiger Lily). Each 10c; doz., \$1.00.

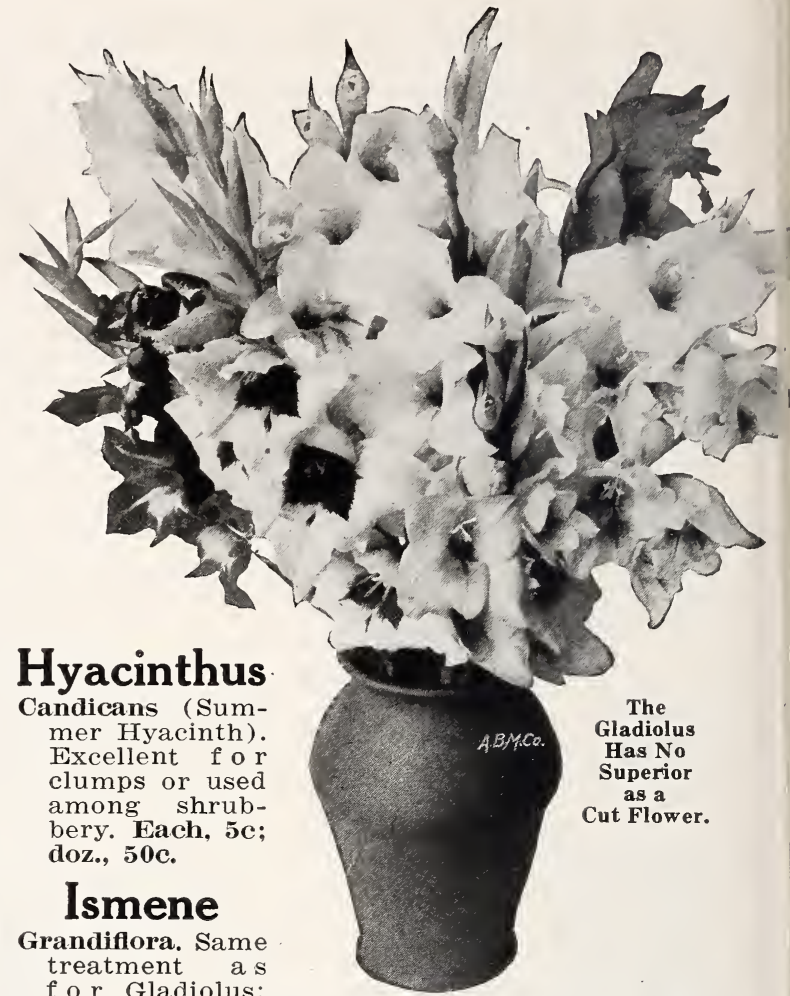

flower in six to eight weeks after planting. Very beautiful lily-like plant. Extra large bulbs, 20c each; \$2.00 doz.

\section{Madeira Vine}

A rapid growing vine with fragrant white flowers. 5c each; 50c doz.

\section{Montbretias}

Hardy summer-flowering bulbous plants, with brightly colored flowers, borne in long spikes. Bouquet Parfait. Vermilion, golden center. Crocosmiaeflora. Scarlet and yellow.

Etoile de Feu. Bright vermilion.

Oblisque. Yellow.

Rayon d'Or. Yellow, spotted brown.

Sulphurea, Pale yellow.

5c each; 30c doz., 100 for $\$ 2.00$.

\section{Oxalis}

These summer flowering bulbs should be planted out early in May, about two inches deep. Mixed colors, 20c doz.

\section{Tuberoses}

In this latitude May 1st is ample time to plant in the open ground, but the bulbs can be started in pots much earlier if desired. Select a warm soil and a sunny spot. The soil should be rich, but no especial preparation is necessary. Place the bulb so the top will be covered about one inch with soil.

Excelsior Pearl. Extra fine large flowering bulbs. 5c each: 35c per doz.: $\$ 2.50$ per 100 . Add $10 \mathrm{c}$ per dozen if sent by mail.

\section{Tigridias}

(Shell Flower.) Free flowering, gorgeous colored flowers. $1 \frac{1 / 2}{2}$ feet high. Treat like Gladiolus. Aurea. Golden yellow.

Grandiflora Alba. White with red spots.

Immaculata Alba. Pure white.

Lilacea. New; lilac.

Pavonia. Bright red.

Rosea. Rose.

5c each: s5c per doz.; \$2.50 per 100. 


\section{Hardy Herbaceous Perennials}

Aquilegia. An assortment. Finest mixed. Many fine sorts. Each, 15c; doz., \$1.50.

Chrysanthemum. These hardy sorts bloom in August and continue until frost. They are valuable for cut flowers. Height, 2 feet; assorted. Each, 20c; doz., \$2.00.

Coreopsis Grandiflora. The largest and finest perennial sort; flowers golden yellow; July to October; 18 inches. Each, 20c; doz., \$2.00.

Dielytra Spectabilis (Bleeding Heart). Long racemes of pink and white heart-shaped flowers; May and June. 2 ft. Each, $25 c$ and 50c.

Delphinium (Larkspur). Very ornamental plants, producing tall flower spikes of great value to cut for vases. They commence to bloom in July and if not allowed to seed will continue until frost. Height, $3 \mathrm{ft}$. Each, 25c; doz., \$2.50.

Dianthus Barbatus (Sweet William). Makes a fine display in the garden. Flowers perfectly double; richness and variety of coloring; beautifully marked; mixed. Each, 25c.

Digitalis (Foxglove). Flower stalks 4 to 6 feet high, very attractive, spotted varieties. Each, $15 c$; doz., \$1.50.

Funkia Variegata (Day Lily). Each, 20c; doz., 2.00.

Gaillardia Grandiflora. Magnificent hardy plants with large crimson and yellow flowers, blooms from July until frost. Each, 15c; doz., \$1.50.

Gypsophila Paniculata (Baby's Breath). Light and graceful, pure white flowers, excellent for bouquets. $1 \frac{1 / 2}{2}$ feet. Each, 25c; doz., \$2.50.

Hemerocallis Flava (Lemon Lily). Fragrant. Each, 25c; doz., \$2.50.

Hollyhock. Double choicest English. Finest mixed. Each, 20c; doz., \$2.00.

Iris Kaempferi (Japan Iris). Finest of all the Iris family. The flowers are of immense size, from six to eight inches in diameter; should be plentifully supplied with water while growing and flowering. We can supply twenty distinct varieties. Each, 25c; doz., \$2.50.

German Iris (the true Fleur-de-Lis). These flourish either in ordinary soil or in moist situations. Colors of the widest range. Each, 15c; doz., \$1.50.

Peonies. Fine, hardy plants, making an excellent display when well established in clumps on the lawn, and require very little care, as they will grow and do well in any soil, but the flowers will be larger and the color brighter if given rich, deep loam. Choice named varieties: $25 c$ each; doz., \$2.50.

Platycodon, or Wahlenbergia (Chinese Bell Flower). Showy, erect spikes, excellent for cutting. July to Sept.; 2 feet. Grandiflora. Double blue. Each, 20c; doz. \$2.00.

Rudbeckia (Golden Glow). Golden yellow flowers, resembling Chrysanthemums. Blooms in August and September. $4 \mathrm{ft}$. Each, 15c; doz., $\$ 1.25$.

\section{Hardy Phlox}

15c each: \$1.50 per doz.

Coquelicot. Orange scarlet, crimson center.

Epopee. Violet, bright fiery center.

Fernand Cortez. Deep crimson, dark center.

Gen. Chanzy. Bright pink, tinted salmon.

Hector. Fine pink.

Independence. Large pure white.

Jules Jony. Lilac rose, white center.

Le Mahdi. Deep velvety purple.

Mme. P. Tangier. Bright red, vermilion center

Japanese. Delicate rose, white center.

L'Esperance. Light lavender-pink, white center.

R. P. Struthers. Pinkish salmon. Crimson eye.

\section{Hedge Plants}

BARBERRY, Common. $1 \frac{1}{2}$ to 2 feet. Doz., \$1.50; 100 for $\$ 10.00$.

Thunberg's. 18 in. to $8 \mathrm{ft}$ Doz, $\$ 2.25 ; 100, \$ 15$.

PRIVET, California. 1 to $1^{1 / 2}$ feet. Doz., \$1.00; 100 for $\$ 6.00$.

PRIVET, California. 2 to $2 \frac{1}{2}$ feet. Doz., \$1.50; 100 for $\$ 8.00$.

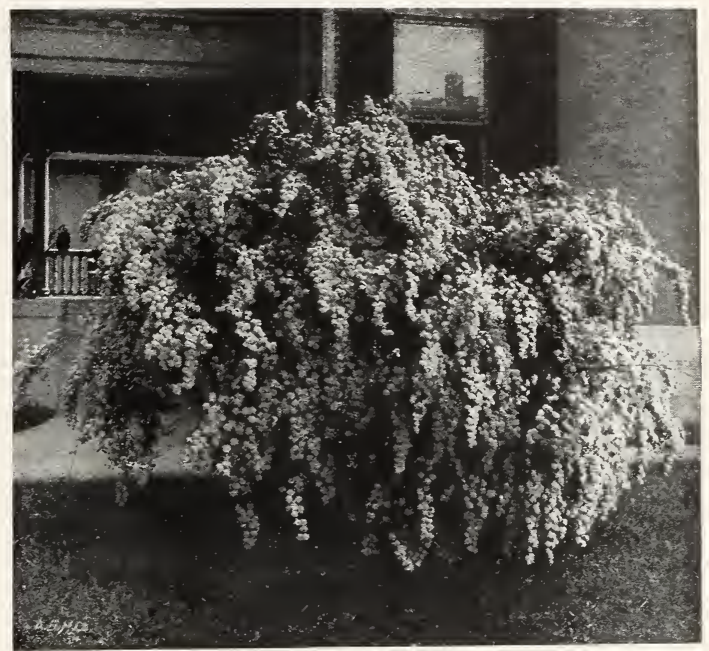

Spirea Van Houtte.

\section{Hardy Ornamental Shrubs}

ALTHEA. Purple, red or white. September. 50c. Variegated Foliaged. Beautiful. Each, 50c.

AZALEA (Pontica or Hardy Ghent). Magnificent flowering hybrids. Each, \$1.00.

Amoena. Beautiful rose flowers and evergreen leaves, Each, $\$ 1.00$ to $\$ \mathbf{2 . 0 0}$.

Mollis. Large, showy and fragrant. Each, \$1.00. CALYCANTHUS Floridus (Spice Bush). Brown flowers; very fragrant. June to Sept. Each, 50c.

DEUTZIA Crenata, Alba Pleno. Double white, very beautiful. June. Each, 35c.

Rosea Plena. Double pink. June. Each, 35c. Gracilis. White; very free; dwarf. June. 35c.

EUONYMUS Americanus (Strawberry Bush). Bears crimson fruit. June. Each, 35c.

Atropurpureus (Burning Bush). Purple; in clusters. June. Each, 50c.

FORSYTHIA Fortunei. Upright growing; golden yellow. May. Each, 50c.

Suspensa (Weeping Golden Bell). Fellow, drooping flowers. April. Each, 50c.

HYDRANGEA Paniculata Grandiflora. The showiest of all autumn shrubs, bearing immense heads of creamy-white flowers. August, September and October. Flowering plants, 2 years old, doz., \$5.00; each, 50c. Extra large plants, 3 years old doz., $\$ 7.50$; each $75 \mathrm{c}$.

IIIAC. Common Purple (Syringa). Very fragrant. May. Doz, \$5.00; each, 50c.

Common White. Fragrant. May. Each, 50c. Extra large plants, 3 to 5 ft., doz., $\mathbf{\$ 5 . 5 0}$; each. 75c.

Persian. Purple; very fine. Each, 50c to 75c. Charles $\mathbf{x}$. Reddish purple; trusses large. Each, 50c to $75 \mathrm{c}$.

LONICERA Tartarica (Bush Honeysuckle). Pink, sweet scented. May. Each, 50c.

PRUNUS Pissardi (Purple-leaved Plum). Beautiful. Each, 50c to \$1.00.

Triloba (Double-flowering Plum). Double pink flowers. May. Each, 50c.

RIBES Floridum (Flowering Currant). White, Each. 50c.

RHODODENDRONS. Hardiest hybrids. These plants are of hard, stocky growth and well set with flower buds. Fine plants. Each. \$1.25; doz., \$12.00. Larger plants, each, $\$ 2.00$ to $\$ 5.00$.

SPIREA Callosa Alba. White flowers; May. 50c each.

Anthony Waterer. Brilliant rosy carmine flowers in dense clusters. Two sizes. Each, 50c. Opulifolia. White flowers in clusters; May. 50c. Prunifolia Flore Pleno (Bridal Wreath). Double white; very free. May. Each, 50c.

Van Houttei. One of the finest shrubs; pendulous; pure white flowers in clusters. Each, 50c to $75 \mathrm{c}$. 
SAMBUCUS Amrea (Golden Elder). Broad, golden yellow leaves. Each, 50c to 75c.

SYRINGA, Golden. Philadelphus aurea. Foliage golden vellow; fine. June. Each, 50c.

SYRINGA, Sweet-Scented. Philadelphus Coronarius (Mock Orange). White, fragrant, orange like flowers. June. Each, 50c.

SYMPHORICARPOS Racemosus (Snowberry). Flowers pink with pure white berries in the fall; July. Each, 50c to 75c.

VIBURNUM OPULUS (Snowball). Each, 50c. Plicatum, (Japan Snowball). Large, pure white flowers; beautiful foliage. Each, 50c to 75c.

Variegata. Pink, foliage variegated; June. Each, 50c to $75 \mathrm{c}$.

YUCCA Filamentosa (Adam's Needle). White, stately. Each, 50c to $\$ 1.00$.

\section{Hardy Roses}

Strong potted plants, each 60c; doz., \$6.00. Alfred Colomb. Brilliant carmine crimson; large. Anna de Diesbach. Clear, bright rose.

Baron de Bonstettin. Velvety blackish crimson. Baroness Rothschild. Pale flesh pink, very fine. Capt. Hayward. Bright crimson.

Duke of Edinburgh. Vermilion.

Fisher Holmes. Rich, velvety crimson.

General Jacqueminot. Brilliant scarlet crimson. John Hopper. Brilliant rosy crimson.

Jules Margottin. Bright cherry.

La France. Bright lilac rose; center silvery white. Mabel Morrison. White, faintly flushed with pink. Madame Gabriel Luizet. Fine satiny rose.

Magna Charta. Bright pink suffused with carmine. Margaret Dickson. White, pale flesh center.

Merveille de Lyon. White, center blush.

Mrs. John Laing. Soft pink, superb flower.

Paul Neyron. Deep rose, very large.

Prince Camille de Rohan. Velvety crimson.

Uhich Brunner. Cherry crimson.

\section{Perpetual Blooming Roses}

Maman Cochet. Pink, white. Baby Rambler, Baby Dorothy Perkins, Kaiserine Augusta, Killarney, American Beauty, Chas. Lefebre, Soleil d'Or, Gruss an Teplitz. Potted plants. Each, 75c; doz., \$8.00.

\section{Fruit Trees}

\section{APPLES}

Price, 4 to 6 feet, 50 each; $\$ 5.00$ doz. 6 to 8 feet, \$1.00 each. Extra size, \$1.50 each.

Sumnier Apples. Early Harvest, Red Astrachan, Sweet Bough, William's Favorite.

Autumn Apples. Duchess, Gravenstein, Maiden's Blue, Porter.

Winter Apples. Baldwin, Golden Russet, Hubbardston Nonesuch, Northern Spy, Rhode Island Greenings, Talman Sweet.

\section{PFARS}

2 to 3 year's, $\$ 1.00$ to $\$ 1.50$. Dwarf, some varieties, $75 \mathrm{c}$ to $\$ 1.00$.

Favorite, Seckel, Sheldon, Buerre de Anjou. Keiffer and Vermont Beauty.

\section{PEACIIES}

Price, 25c to $50 \mathrm{c}$ each; $\$ 2.50$ to $\$ 5.00$ per dozen. Crawford's Early, Crawford's Late, Champion, Elberta, Mt. Rose, Old Mixon, Rare-Ripe, Stump the World, Rag Peach, 75c.

\section{PLUMS}

Price, 2 to 3 year's, $75 \mathrm{c}$ each, $\$ 7.50$ per dozen. Larger trees, $\$ 1.00$ and upwards.

Bradshaw, Cole's Golden Drop, Imperial Gage,

Lombard, German Prune, Burbank, Abundance and Wixon.

\section{CHERRIES}

Price, 2 to 3 years, $\$ 1.00$ each. Large trees, $\$ 1.50$ and upwards.

Black Tartarian, Black Eagle, Black Heart, Coe's

Transparent, Early Richmond, Governor Wood, May Duke, Rockport, Bigarreau.

\section{Hardy Climbing Roses}

Crimson Rambler. The blossoms are borne in immense clusters, brilliant crimson color. Flowering plants, potted plants, each, $75 \mathrm{c}$ and $\$ 1.00$. Dorothy Perkins. The finest pink running rose in existence. Potted plants, 75c to $\$ 1.00$ each.

\section{Hardy Climbing Plants}

MMPELOPSIS Veitchii (Japanese Woodbine). Known as Eoston Ivy; the beautiful hardy climber, conspicuously attractive on our finest streets and buildings. Eacl. 25c; doz., \$2.50. Extra size, each, 35c; doz., \$3.50.

Quinquefolia (Virginia Creeper). Each, 35c to $50 \mathrm{c}$.

ARISTOLOCHIA Sipho (Dutchman's Pipe). Very large foliage and curiously shaped flowers. Two sizes. Fach, 75c and \$1.00.

BIGNONIA, or TRUMPET FLOWER. Handsome, scarlet flowers. Two sizes. Each, 50c to $75 \mathrm{c}$

HONEYSUCKLE. Japan Variegated. Leaves yelIow and green. Each, 35e to 50c.

Belgian. Very sweet; red and buff flowers. Fach, 30c to 50c.

Hall's Japan or Halleana. From Japan; white, fragrant and fine. Each, 35c to 50c.

WISTARIA, Chinese Purple. The finest of climbing plants; purple flowers. Each, 750 to $\$ \mathbf{1 . 0 0}$. Chinese. White. Similar, but with white flowers. Each, 75c to $\$ 1.00$.

\section{Clematis}

A most beautiful class of hardy, free-flowering climbers. Plants of our importation, strong and finely rooted.

PANICULATA. This lovely white variety, with its thousands of fleecy, small, star-like flowers, is one of the finest climbing plants known. It bears so profusely and in such dense but airy clusters that the whole plant appears as one mass of bloom, with dark, shining foliage enough only to give effect to its beauty. It is deliciously fragrant, is a very rapid climber, flowers freely the first year, and is perfectly hardy. Flowering plants, each, extra large plants, 50c; doz., \$5.00.

JACKMANNI. One of the best; fine, rich purple. Each, 75c.

\section{QUINCE}

Orange and Champion, 75c to $\$ 1.50$ each. Tree form, \$1.50.

\section{Small Fruits}

\section{CURRANTS}

\section{$\$ 1.25$ per dozen.}

Black Naples, Cherry Red, Versailles, Victoria, White Grape, Fay's Prolific-largest and finest red variety; very prolific.

\section{BLACKBERRIES}

$\$ 1.00$ per dozen: $\$ 6.00$ per 100.

Agawam, Dorchester, Kittatiny, Snyder, Wachusett, Wilson's Early.

\section{GRAPES, HARDY VARIETIES}

2 to 3 years, 35c each; $\$ 3.00$ per dozen.

Concord, Delaware, Hartford, Moore's Early, Niagara, Salem, Wilder, Worden, Campbell's Early, Green Mountain.

\section{GOOSEBERRIES}

$\$ 2.00$ per dozen.

Downing, Industry-dark red, very large and productive; Joslyn, the largest sort

\section{RASPBERRIES}

$\$ 1.00$ per dozen.

King, Cuthbert, Golden Queen, Gregg, Marlboro, Souhegan.

\section{STRAWBERRIES}

$\$ 1.00$ per 100

Beder Wood (S), Bubach No. 5 (P), Clyde (S), Gandy Prize (S), Glen Mary (S), Haverland (P), Jessie (S), Marshall (S), Nick Ohmer (S), Sample (P), Sharpless, Norwood. 


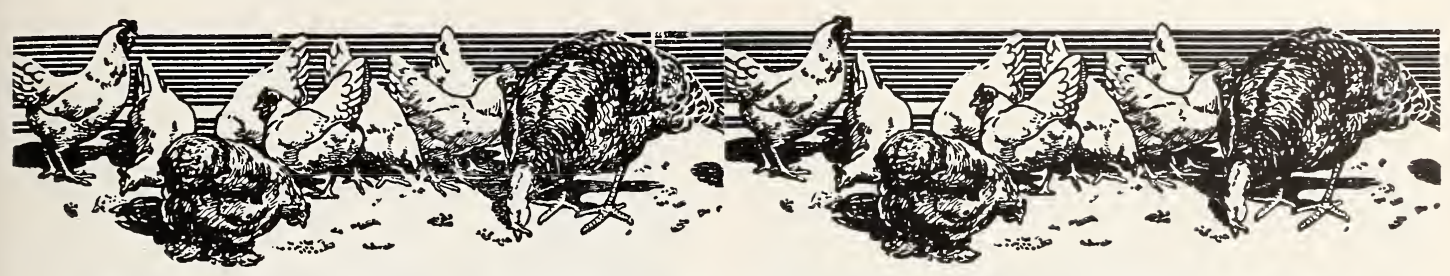

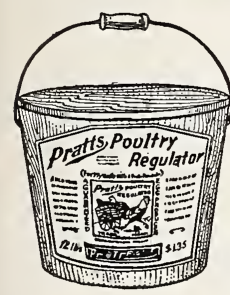

Healthy birds and lots of eggs, the two big things in poultry raising, are made certain by giving

\section{Pratt's Poultry Regulator}

100 lb. bags, $\$ 9.00$; 25 lb. pail, $\$ 2.50$; 12 lb. pail, \$1.25; packages, 50c and 25c. It builds up vitality, insures sound digestion, sharpens appetite and prevents disease, thus putting birds in condition for heavy egg laying or winning blue ribbons. Pratt's is the original Poultry Regulator of America and is in use by the most successful poultry raisers everywhere. When regularly used, hens lay throughout the year. It will prevent chicken cholera, gapes, roup, rheumatism, expel worms, prevent leg weakness and egg eating. It will greatly improve turkeys, geese, ducks, pigeons and guineas insuring quick growth and keep them free from disease.

Get rid of lice on your poultry, in nests, dust baths, incubators and elsewhere in a day's time by using

\section{Pratt's Powdered Lice Killer}

$50 \mathrm{c}$ and $25 \mathrm{c}$

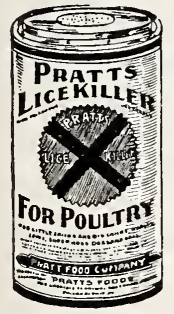

Effective, non-poisonous, non-irritating. May be used wherever a powder is suitable. A splendid deodorizer.

It quickly and thoroughly kills all lice on little chicks, big chicks, setting hens and incubator chicks. It rids horses, cattle, hogs, dogs and cats of lice, and destroys ticks on sheep. It destroys insects and bugs on vines, plants and flowers. A valu. able deodorizer and disinfectant for all poultry houses, barns, stables and dwelpoultry houses, barns, stables and dwel-
lings. Drives out moths from closets, furniture, carpet and clothing.

\section{Poultry Supplies}

GREEN'S FIRST FEED FOR BABY CHICKS. A complete pre-digested baby food that we have sold the past few seasons with excellent results. Recommended for the first three weeks, to be followed by Green's second feed. 5-lb. pkg., 25c.

GREEN'S SECOND FEED. A well balanced feed for chicks from three weeks old to maturity. We believe this the best proportioned feed offered and we have sold with excellent results for several years. 5 lbs., 25c; 10 lbs., 40c; 25 lbs., $75 c ; 100$ lbs., $\$ 2.75$.

CONKEY'S ROUP CURE. A guaranteed remedy for all forms of roup. Directions in each package. Price, 50c and $\$ 1.00$.

SHERIDAN'S CONDITION POWDER. Prevents and cures diseases of hens. It is strictly a medicine to be given in small doses once daily in their food. Price, per pkg., 15c; large pkg. 75 .

SMITH'S INSECT POWDER. A superior powder for poul-

try use. 25c. of the poultry ills. Pkg., 10c; 10 lbs., 40c.

SMITH'S ROUP CURE. 25c.

MICA CRYSTAL GRIT. For Chickens, Geese, Turkeys, Pigeons and Birds. It makes thorough digestion of food possible. Two grades for chicks and poultry. Price, per package, 10c; 100-lb. bag, 90c

GROUND OYSTER SHELLS. Furnishes one of the best sources for shell-making material. Thoroughly washed and and dried. Price, per package, 10c; 100-lb. bag, 90c.

DRINKING FOUNTAINS. Sanitary, square, galvanized, in two parts, easily cleaned and filled. Price, 1 gallon, 50c; 2 gallons, $85 \mathrm{c}$.

ANITARY FEED BOX. Made of galvanized iron with three spaces. Price, 50c.

LEG BANDS. Aluminum. Per doz., 15c; per 100, 75c. INSECT POWDER BELLOWS. Each, $\$ 1.00$ and $\$ 2.00$. PORCELAIN NEST EGGS. Price, 3c each; doz., 25c.

EGG TESTERS. Made of tin; will fit any small lamp. Each, 35c.

EGG BOXES. Doz., $15 c ; \$ 1.00$ per 100 .
When baby chicks come, keep them healthy and growing and bring even the weak ones along by feeding

\section{Pratt's Baby Chick Food}

14 lbs, for $\$ 1.00$. Packages $25 \mathrm{c}$ and $50 \mathrm{c}$.

A largely predigested baby food for baby chicks. Guaranteed to raise every livable chick. Costs a cent a chick for three weeks. Prevents leg, weakness, chick diseases.

PRATT'S CONDITION TABLETS. 25c and 50c.

PRATT'S SORE HEAD CHICKEN POX REMEDY. 25c and $50 \mathrm{c}$.

PRATT'S ROUP REMEDY. Tablets or Powder. \$1.00, 50 and 25c.

PRATT'S POULTRY DISINFECTANT. $\$ 1.00$ gallon; $35 \mathrm{c}$ quart.
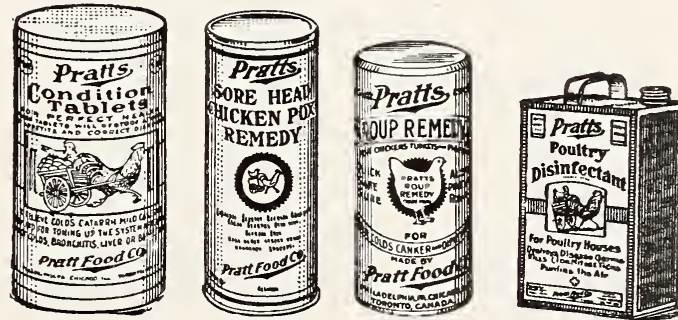

\section{Fertilizers}

SHEEP MANURE, Pulverized. This is a pure natural manure, and the most nutritious food for plants. It is excellent as a top dressing for lawns. There is nothing better for mixing with the soil for greenhouse plants; one part manure and six parts soil. For use in the vegetable garden, placed directly in hills or drills, it promotes a rapid and steady growth. 2-1b. package, 15c; 5 lbs., 25c ; 10 lbs., 40c; 25 lbs., 75c; 50 lbs., \$1.25; 100 lbs., $\$ 2.00$.

UNLEACHED HARDWOOD ASHES. As a fertilizer for lawns, gardens and fruits, Hardwood Ashes are unequaled they are not a mere stimulant, but supply natural plant food, permanently enriching the soil. Price, $100 \mathrm{lbs} ., \$ 1.75$. MITCHELL'S SPECIAL HIGH GRADE FERTILIZER. Contains all the necessary elements of plant food, in the most obtainable form to meet the wants of all plants in all periods of their growth. Per 100 lbs., \$2.50; 50 lbs., \$1.50.

LAND PLASTER. Used for preventing bugs from destroying cucumber, melon and squash vines. Price, package, $25 \mathrm{c}$; per bag, $90 \mathrm{c}$.

BOWKER'S FOOD FOR FLOWERS. A dressing made expressly for plants grown in the house, garden or conservatory. Clean, odorless, and producing early and abundant blossoms, and healthy, luxuriant plants. Small packages, enough for thirty plants for three months. 15c each. Large package, 25 c

BOWKER'S LAWN AND GARDEN DRESSING. Prepared from chemicals free from weed seed, clean to handle, easily applied. 100 lbs., \$3; 25 lbs., \$1; 10 lbs., 50c; pkg., 10c. BON ARBOR. A complete plant food, immediately soluble and applied directly to root of all plants, giving healthy, lasting growth. 1-oz., package, 25c; 1-lb. package, 50c.

PURE GROUND BONE MEAL. This finely pulverized ground bone is excellent for rose culture, top dressing for lawns and for potted plants. 5-lb. package, 30c; 10 lbs., $50 \mathrm{c} ; 50$ lbs., $\$ 1.50 ; 100$ lbs., $\$ 2.50$.

NITRATE OF SODA. This is valuable solely for the nitrogen it contains, equal to 20 per cent of ammonia. Being extremely soluble, it should not be applied until the plants are above ground, when 100 to 500 pounds per acre. 5 lbs. $40 c ; 10$ lbs., 75c; 100 lbs., $\$ 6.00$. 


\section{Insecticides}

APHINE. A liquid spray for greenhouses and outdoor use, killing lice of every species. $1 / 2$ pt., 40c; pt., 65c; qt., $\$ 1.00$; gal., $\$ 2.50$.

ANT DESTROYER. A non-poisonous powder which sprinkled around their haunts will drive black ants from lawn, etc. Pkg., 20c.

ARSENATE OF LiSAD. A poison rapidly taking the place of Paris Green. Adheres well to the foliage and will not burn the tender leaves. Lb., 30c; 5 lbs., $\$ 1.10 ; 10$ lbs., \$2. APHIS PUNK. A special preparation of nicotine for the extermination of green and black fly, thrip, etc. Not injurious to delicate plants. Per package, 12 rolls, 60c.

BORDEAUX MIXTURE. For all fungoid diseases, such as mildew and various rots of grapes, etc. 1 gal. can, $\$ 1.25$ 1 qt., 50c; 1 pt., 30c.

BUG DEATH. A non-poisonous powder that takes the place of Paris Green and other dangerous insect powders. When used as directed it is sure death to potato, squash and cucumber bugs, currant and tomato worms, etc. 1 lb. 20c; 3 lbs., 45c; 5 lbs., 60c; 121/2 lbs., \$1.20.

"BLACK LEAF 40." For destroying aphis, thrips, etc., without injuring the foliage. 1 oz. bot., $25 c$.

CUT WORM KILLER (Sterlingworth). Most effective cut worm killer yet introduced; non-poisonous. 1 lb., 25c; 5 lbs., $\$ 1.00$.

LIME-SULPHUR SOLUTION. This preparation is scientifically prepared and is widely recommended and known 's one of the best preparations for San Jose's scale, oyster shell scale, etc. Apply fall and spring while leaves are off. One application is not sufficient, as many of the scales get under the rough bark and are difficult to reach. Ready for use by adding 16 to 20 gallons water to each gallon of mixture. 1 gallon, 75c; 5 gal., $\$ 2.25 ; 50$ gal. bbl., $\$ 10.00$

STERLINGWORTH WEED KILLER, for killing weeds in walks, drives, tennis courts, etc. 1-lb. box, 50c each; 5-lb. box, $\$ 2.00$ each.

GRAPE DUST. A preparation to kill the destructive mildew that strikes the grape vine; also for like use upon any other plants or trees affected with mold, mildew or rust mites, either in greenhouses or the open air. 1 lb., 20c; 5-lb. pkt., $40 \mathrm{c}$.
HELLEBORE. Powdered White Hellebore for rose slugs, currant worms, etc. Dust on with gun or bellows while the foliage is moist.

KEROSENE EMULSION. For aphis on all plants. Ready for use by simply adding water. Quart, 40c; gal. cans, $\$ 1$. NIKOTEEN. Is the cheapest, cleanest and most effective of insecticides, and will not injure or discolor delicate plants. It is composed of that element in tobacco which gives it its value as an insecticide and nothing else. Bottle, 40c, $85 \mathrm{c}$ and $\$ 1.50$

NICO-FUME (Tobacco Paper). 24 sheets, 85c; 1 gross, $\$ 4.00 ; 2$ gross, $\$ 7.50$.

NICO-FUME LIQUID. 1-lb. tin, $\$ 1.50 ; 4-1 b$, tin, $\$ 5.50 ; 8$ lb. tin, $\$ 10.50$.

PARIS GREEN. Superior quality. 1/2 lb., 30c: 1 lb., 50c.

PYROX. Insecticide and fungicide for all leaf-eating insects. 1 lb., 25c; 5 lbs., $\$ 1.00 ; 10$ lbs., $\$ 1.75$.

SLUG SHOT. Destroys all insects injurious to house and garden plants, vegetables and fruits of all kinds, Equals Paris Green when used liberally without the danger from poison. Price, 1 lb., 15c; 5-lb. package, 35c.

SCALECIDE. The latest and best spray for San Jose scale. A mechanical preparation of petroleum oil that instantly mixes with cold water. One gallon of Scalecide to 20 gallons of water sprayed on your trees and bushes will kill every scale that it reaches without injury to tree or fruit bud if applied in late fall, winter or early spring while the foliage is off. Price, qt., 40c; 1 gallon can, $\$ 1.00 ; 10$ gallon can, $\$ 6.00 ; 50$ gallon barrel, $\$ 25.00$.

SULPHUR, FLOWERS OF. A staple preventive for mildew on grapes, roses, etc. Lb., 10c; 10 lbs., 50c.

TOBACCO SOAP. Makes an excellent wash for plants and trees infested with green fly, lice and eggs of insects. Dissolve 2 ounces in gallon of water. Pkt., 20c.

TOBACCO DUST. If dusted on while the foliage is moist it destroys rose lice, cabbage and turnip fleas, etc. Spread upon the ground, it keeps off earth insects and acts as a fertilizer. Per lb., 10c; 2 lbs., $15 c ; 5$ lbs., 30c; 100 lbs., $\$ 4.50$. TOBACCO STEMS for Fumigating. Price on application.

FISH OIL SOAP. Commonly known as Whale Oil Soap. Makes an excellent wash for trees and plants; kills insects and eggs on the bark. Per lb., 20c.

\section{Garden Tools and Requisites}

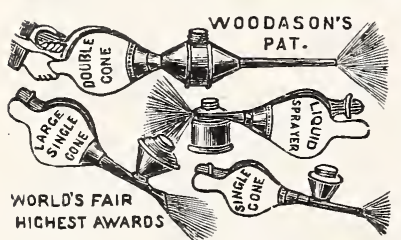

Bellows. W oodason's Powder. For Hellebore, Tobacco Dust, etc. Each, $\$ 1.15$ and $\$ 2.00$ Bellows. Sulphur. Used for Sulphur, \$1.75. Baskets. Verbena. Ad justable wooden han dles with tin fasten ings on the ends. Small size, $10 \times 5,3$ inches deep, $\$ 2.00$ per 100 .

Dibbles. Used in transplanting cabbages, etc. Steel points, $35 \mathrm{c}$ each.

Forks, Digging or Spading, 90c each. Hay or stable, 35c to $75 \mathrm{c}$ each. Manure, long or short handles, $75 \mathrm{c}$ to $\$ 1.25$.

Hoes. Draw, with handles, 40c and 45c each. Hoes, scuffle or Dutch, 40c to 65c each. Plympton, 60c. Warren, 60c.

Hose, Rubber. Excellent quality, in 25 and 50 foot lengths: $1 / 2$ in.. 13e per foot; $3 / 4$ in., 14 c per foot.

Hose. Extra quality; recommended for greenhouse use; 1/2 inch, $17 \mathrm{c}$ per foot; $3 / 4$ in., $18 \mathrm{c}$ per foot.

Fumigators. Eureka. For smoking greenhouses with dampened tobacco stems. No. 2 holds one peck of stems, $\$ 2.00$. No. 3 holds $1 / 2$ bushel stems, $\$ 2.50$. No. 4 holds $3 / 4$ bushel of stems, $\$ 3.25$.

Garden Lines. Cotton, braided, 48 feet, 45c.

Reels for above. 50c each.

Glazier Points. Peerless. Double pointed steel wire, galvanized. Box of $1,000,60 \mathrm{c}$.

Glazing Points. Sieberts. Zinc, will not rust; two sizes, $5 / 8$ and $1 / 8$ in. long. Lb., 50c.

Grafting Wax. 1/4 package, 10c; $1 / 2$ lb., 15c; 1 lb., 25c.

Grass Hooks (Sickles). English, each, $40 \mathrm{c}$ and $50 \mathrm{c}$.

Grafting Chisels. 60c.

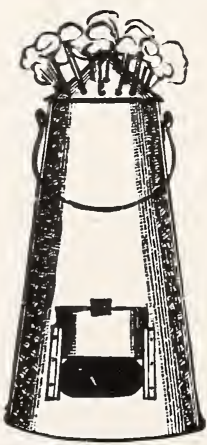

Fumigator

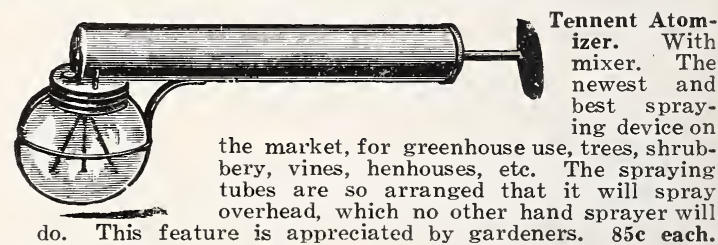

Hose Couplings. Set, 20c.

Hot Bed Mats. Palmer's. Wool filled, frost proof. Made expressly for winter covering of hot beds, cold frames, plants, etc. Price, burlap covering, 76 in. $x$, 76 in.; water. proof duck, one side. Prices upon request.

Knives. Budding and pruning, \$1.00.

Knives. Asparagus. For cutting asparagus under the surface. 50c each.

Edging Knife. Handled. 75c.

Lawn Rakes. Wooden, best quality. 65c each.

Lawn Sprinkler. Water Witch, No. 3. 50c each.

Hose Menders. Cooper's. Made of heavy brass. Requires no wire or plyers to adjust them. For $1 / 2$ inch or $3 / 4$ inch hose, 8c each, dozen, 75c; 1 inch, 10c each, 85c doz.

Hose Nozzle. Boston Rose spray. Copper face, flat. One of the best nozzles for greenhouse, flower garden or lawn. 50c.

Hose Nozzles. Spraying. Bordeaux, 75c; Vermorel, 75c; Demorel, 60c.

Hose Nozzle. New Boston Spraying. Coarse or fine spray, large or small stream. 40c.

Tremlow's Old English Glazing Putty. For bedding glass in sash or for filling cracks or seams in roof joint or frames of greenhouses or hot beds. Once set on dry wood it does not heave. Gallon, $\$ 1.75$.

We import large quantities of Fall Bulbs and handle strictly first quality. 
Pruners. Water's Tree. This pruner never fails to cut the slightest twig. It is the cheapest and most practical pruner on the market. $6 \mathrm{ft} ., 75 \mathrm{c} ; 8$ ft., $85 \mathrm{c} ; 10 \mathrm{ft} ., \$ 1.00 ; 12 \mathrm{ft} ., \$ 1.10$. Pruners. Telegraph, without handles. $\$ 1.25$ each.

Pumps. Perfect Success Bucket Spray. The best and most durable portable hand pump. It has large air chamber, double acting, throws continuous stream either solid or in fine spray. $\$ 4.50$.

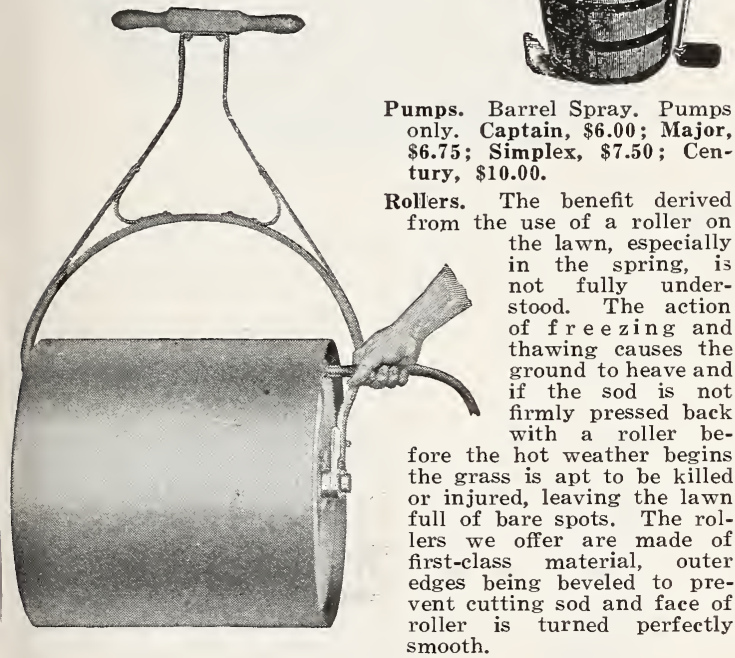

DURHAM WATER WEIGHT ROLLERS.

Weight Filled Filled

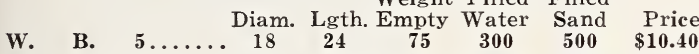

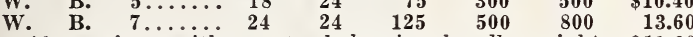
Above sizes, with counter-balancing handle weights, $\$ 11.60$ and $\$ \mathbf{1 4 . 8 0}$. Quotation on other sizes and styles upon application.

Auto Spray. Four gallon capacity, easily carried. One pumping will spray about ten minutes. Our tanks all have the patent Auto Pop control.

Galvanized Iron, with Auto Pop, $\$ 5.50$.

Brass, with Auto Pop, \$8.50.

Saws, Pruning. 18 inch, 90c; 20 inch, $\$ 1.00$.

Scythes. Cast steel. Best quality, $\$ 1.00$ to $\$ 1.50$.

Scythe Stone. Talacre, oval, 25c each.

Shears. Grass border. English. 9 inch, $\$ 2.95$; 10 inch, $\$ 3.00$.

Rakes. Garden steel, 12 teeth, 55c; 14 teeth, 60c; 16 teeth, 65c.

Shears. Hedge. 8 inch, $\$ 1.30$; inch, $\$ 1.50$; 10 inch, $\$ 1.75$; with notch, 25c extra.

Shears. Hand pruning. French, $\$ 1.25$ to $\$ 1.75$ each: German, $\$ 1$ each; American, 60c.

Shears. Sheep. Used for trimming grass borders, $40 \mathrm{c}$ to $\$ 1.00$.

Shovels. Ames' square and round pointed, long or short handles, $\$ 1.50$.

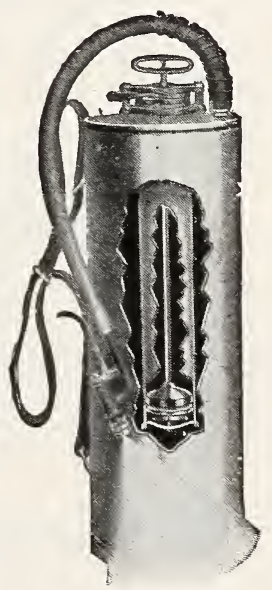

Auto Spray.

Shovel. Steel. $\$ 1.00$ each.

Spades. Steel. $\$ 1.00$ to $\$ 1.50$.

Sprayers. Matchless. 50c each.

Sprayers. Woodason Bellows. For the application of all liquid insecticides. \$1.25.

Sprinkler. Scollay's Rubber. For florists' use and window gardening. \$1.15 each.

Sprinkler. Angle-neck. For spraying under leaves. \$1.25. each.

Silkaline or Smilax Thread. Used in floral work and for stringing smilax. 2 oz. spool, 25c.

Thermometers. Tested and guaranteed. Japanned tinned case, 7 inch, 50c; 8 inch, 60c; 10 inch, 70c each.

Thermometers. Incubator. Various patterns, 60c each.

Thermometers. Brooder: 50c each.
Thermometers. Hot Bed and Mushroom Bed. Boxwood, brass tip, made for plunging. $\$ 1.75$.

Tree Scraper. Hardwood handle. 50c each.

Trowels. Garden. Forged steel. 6 inch, $45 \mathrm{c}$; 7 inch, $50 \mathrm{c}$.

Trowels. Garden. Common steel blade. 10e each.

Trowels Garden. Solid steel, 6 inch, 30c each.

Wheelbarrows. Custom-medium, \$4.50; large, \$5.00.

\section{Watering Pots, Galvanized}

Made from the best quality iron and galvanized after being made. The strongest watering pot made. The joints are brass. Two copper face roses go with each pot for fine and coarse watering. 6-quart, $\$ 2.25$; 8-quart, $\$ 2.50 ; 10$-quart, $\$ 2.75 ; 12$-quart, $\$ 3.00$.

Watering Pot, French Pattern Same as above in quality, oval in shape, with brass handle. 6quart, $\$ 2.50 ; 8$-quart, $\$ 2.75 ; 10$ quart, $\$ 3.00 ; 12$-quart, $\$ 3.25$.

Watering Pots. Green painted. Tin with zinc rose. Heavy material

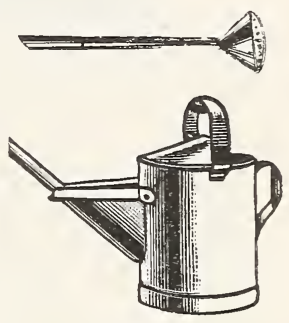
and extra well made. 4-quart,

$60 \mathrm{c} ; 6$-quart, $80 \mathrm{c} ; 8$-quart, 90c; 10 -quart, $\$ 1.10$; 12-quart, $\$ 1.35$.

Watering Pots. Painted. For window gardening without rose. 2-quart, 60c; 3-quart, $75 \mathrm{c}$.

\section{Norcross Cultivator Hoes and Weeders}

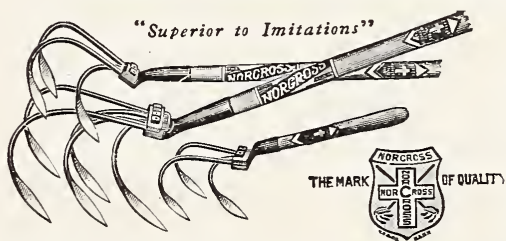

The prongs are spring steel, attached to malleable head by four bolts. toosening the nuts releases one or more prongs without removing bolts. Extremely popula. implements.

5 prong Cultivator Hoe, 4 foot handle ..........\$ 50.85 3 prong Cultivator Hoe, 4 foot handle ..............60

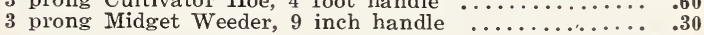

\section{Weeders}

Excelsior. Used for loosening the soil in borders and beds. Each, 10c.

Hazeltine. Each, 25c.

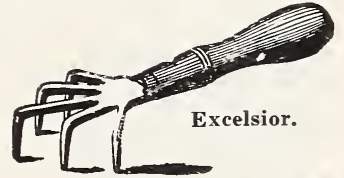

\section{Plant Stakes}

HEAVY or DAHLIA STAKES

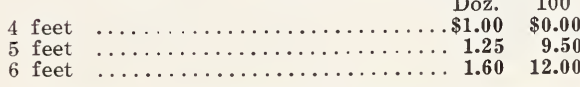

ROUND, TAPERING-PAINTED GREEN

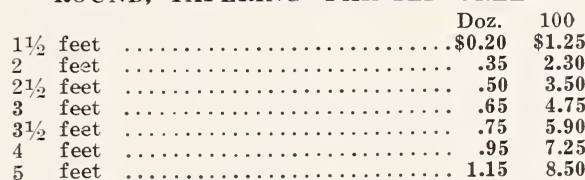

PLANT STAKES-PAINTED GREEN-SQUARE

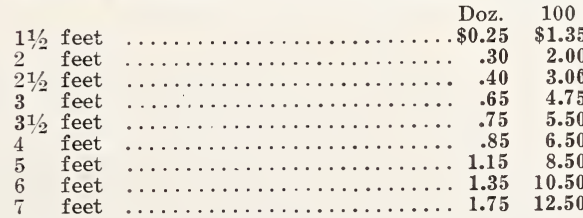

Cane Stakes. Can be cut to any desired length much used by florists for supporting roses, carnations, lilies, etc. 6 feet, doz., 15c; $\$ 1.00$ per $100 ; 8$ feet, 25c doz.; $\$ 1.50$ per 100 .

Pointed Match Sticks. Green, 12 inch, 5c doz. 20c per $100 ; 18$ inch, 5c doz.; 25c per 100 .

Galvanized Wire Stakes. Straight, largely used for supporting carnations. 2 ft., $\$ 1.00$ per 100 3 ft., $\$ 1.50$ per 100 . 


\section{Basketry Supplies}

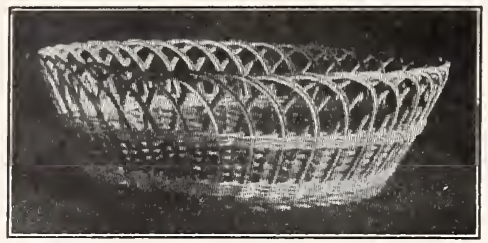

Raffia Natural and Colored. Reed No. 1 to No, 8

Wood Bottoms. Chair Cane. Binding. Flat Reed. Instruction Books.

\section{Plant Trellis}

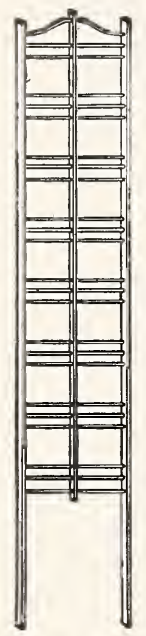

2 feet Veranda $\ldots \ldots \ldots \ldots \ldots \ldots \ldots \ldots \ldots . . \$ 0.50$ 3 feet Veranda
4 feet Veranda $\ldots \ldots \ldots \ldots \ldots \ldots \ldots \ldots \ldots \ldots \ldots$
6

4 feet Veranda $\ldots \ldots \ldots \ldots \ldots \ldots \ldots \ldots \ldots, \mathbf{. 7 0}$

6 feet 28 inches wide

7 feet 18 inches wide

8 feet 18 inches wide

8 feet 28 inches wide

10 feet 20 inches wide

10 feet 31 inches wide

12 feet 20 inches wide

2 feet fan trellis, 10 inches wide at top. $\quad 25$

3 feet fan trellis, 16 inches wide at top. $\mathbf{. 6 5}$

4 feet fan trellis, 32 inches wide at top. 1.20

5 feet fan trellis, 32 inches wide at top. 1.20

6 feet fan trellis, 38 inches wide at top. 1.35

7 feet fan trellis, 42 inches wide at top. 1.50

8 feet fan trellis, 46 inches wide at top. 1.70

Standard Flower Pot

Measurements from Inside to Inside. Width and Depth Equal.

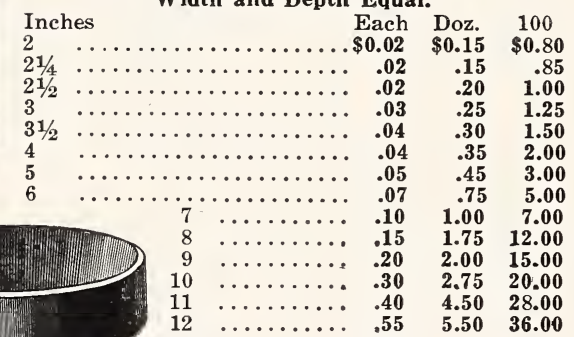

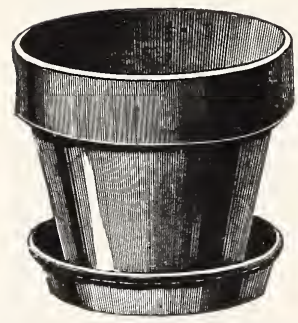

$12 \quad \ldots \ldots \ldots \cdots, .55$

$14 \ldots \ldots \ldots \ldots, 1.00$

$15 \ldots \ldots \ldots \ldots 1.50$

(n)

18 ........ 3.00

$22 \quad \ldots \ldots \cdots \cdots \cdots, 6.00$

Azalea Pots and Seed or Bulb Pans. Prices same as Standard Pots.

\section{Plant Tubs}

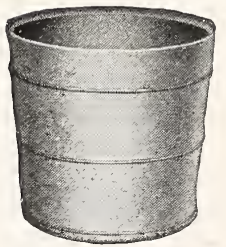

Made of White Cedar, painted, light and attractive.

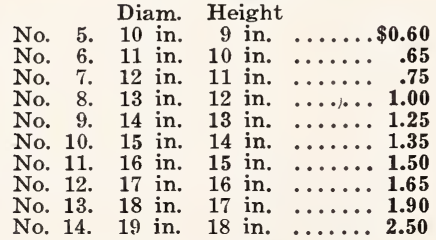

Cedar Plant Tub. Painted green, drop handles. Strongest and most durable plant tub made.

Diam. Top Outside Height Outside

No. 1. 28 inches..........22 inches........\$5.00

No. 2.26 inches.............20 inches........... 4.50

No. 3. 24 inches.............181/2 inches............ 3.75

No. 4. 22 inches........... inches......... 3.25

No. 5. 20 inches........... inches........ 2.70

No. 6.181 inches.............. in inches...........2.20

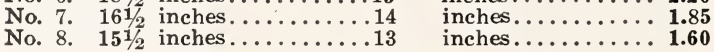

Flower Pot Brackets

Adapted to plain flower pots and saucers. Flat steel, perfectly strong. Can be fastened on narrowest moulding. Black finish. No. 1, for a 5 -in. pot, $30 \mathrm{c} ;$ No. 2, for a 6 -in. pot, $35 \mathrm{c}$; No. 3 , for a 7 -in. pot, $40 \mathrm{c}$ each.
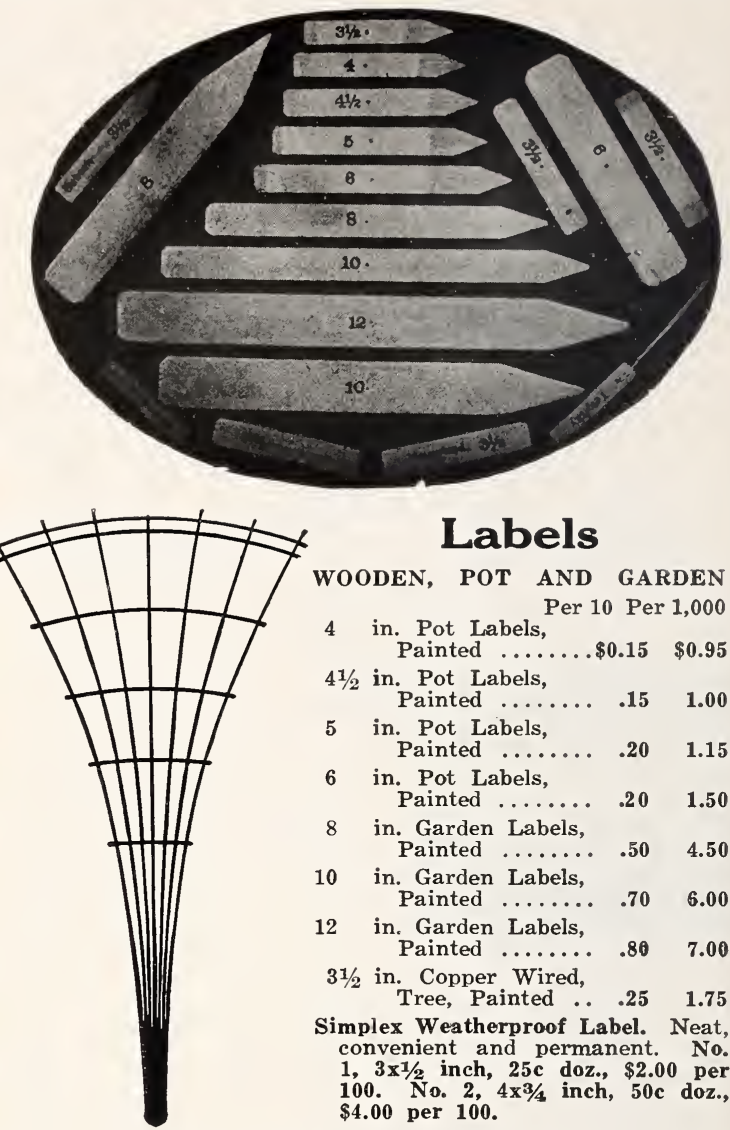

\section{Labels}

WOODEN, POT AND GARDEN Per 10 Per 1,000

4 in. Pot Labels, Painted ......\$0.15 \$0.95

$4 \frac{1}{2}$ in. Pot Labels, Painted .........15 $\quad 1.00$

5 in. Pot Labels,

6 in. Pot Labels,

Painted ........ .20 1.50

8 in. Garden Labels, $1.50 \quad 4.50$

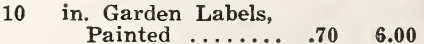

12 in. Garden Labels, $80 \quad 7.00$

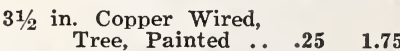

Simplex Weatherproof Label. Neat, convenient and permanent. No. $1,3 \times 1 / 2$ inch, 25c doz., $\$ 2.00$ per 100. No. $2,4 x^{3} / 4$ inch, 50 c doz. $\$ 4.00$ per 100 .

\section{Flower Pot Saucers}

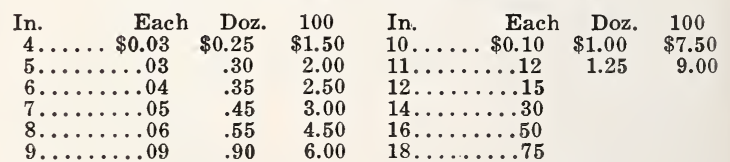

\section{Rolling Stands}

These are made of fibre ware mounted on casters. They are of great convenience for using with the larger size pots and tubs. Being perfectly waterproof they are especially suitable for use in parlors, halls, ete. Each

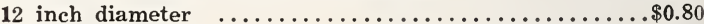
14 inch diameter

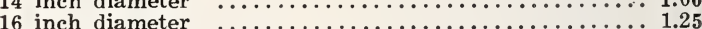

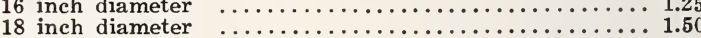
20 inch diameter $\ldots \ldots \ldots \ldots \ldots \ldots \ldots \ldots \ldots \ldots \ldots \ldots \ldots, 1.75$ 22 inch diameter $\ldots \ldots \ldots \ldots \ldots \ldots \ldots \ldots \ldots \ldots \ldots \ldots \ldots \ldots .25$

\section{Folding}

\section{Plant Stand}

Can be opened or folded in a few seconds. Finished in green and bronze. Compact and durable. Takes up very little space when not in use. 3 wire trays, $71 / 2 \times 30, \$ 3.75$.

\section{Wire Window Shelf}

with steel brackets. Can be applied to any window moulding. 30 inch shelf, $75 \mathrm{c}$. 36 inch shelf, $\$ 1.00$. 42 inch, $\$ 1.25$.

Oval Plant Stand 20x30, \$3.00.

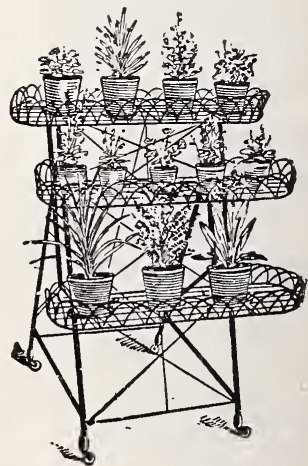


Fern Pans

The pans are especially adapted for linings to porcelain and silver fern pans. Dimensions given are outside measurements.

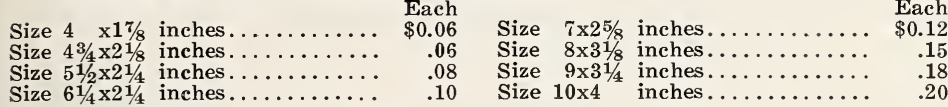

\section{Hanging Pots}

7-inch, 20c each. 8-inch, 25c each. 9-inch, 30c each. 10-inch, 40c each. 12-inch, 60e each.

Chains, 15c each. Hooks, 9-inch, 25c; 12-inch, 30c each.

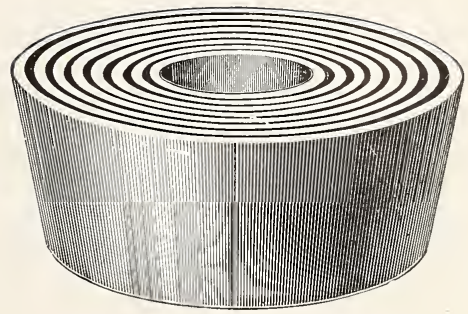

\section{Flower Vases}

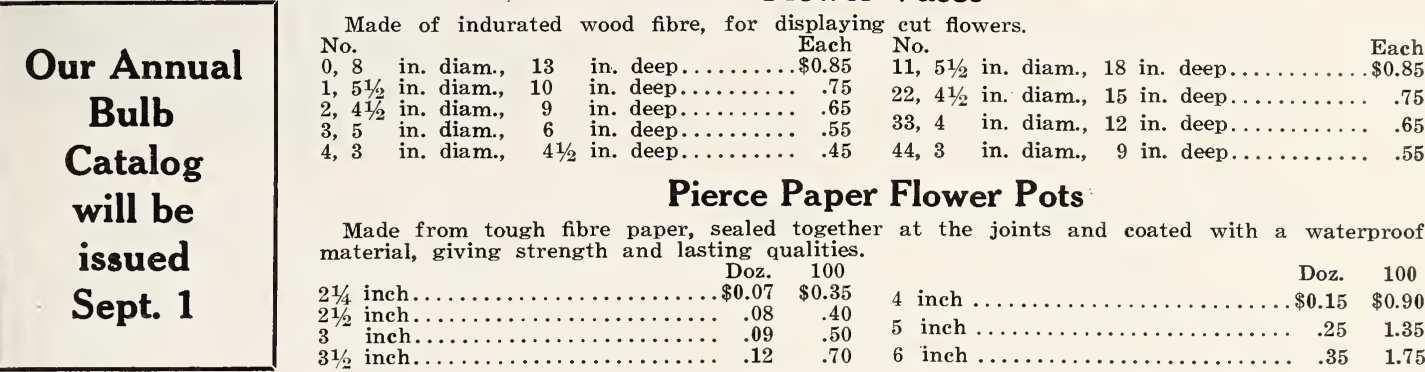

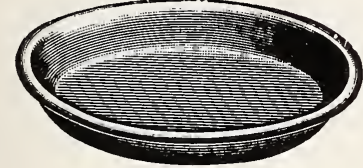

\section{Sundries}

Lawn Mower Oil. 1 qt., 30c; 2 qt., 50c; 1 gal., 75c. Oilers. 15c and 20c each.

Twine. White cotton, best four-ply. 35c per lb. Jute Twine. For tying plants or vegetables, 25c. Tinfoil. 20c per lb. Tinfoil, violet, 50c lb.

Tissue Paper. $\$ 2.00$ per ream.

Wrapping Paper. White. $8 \mathrm{c}$ per lb.

Axle Grease. Quart, 25c; 2 quarts, $40 \mathrm{c}$.

Bouquet Wire. Cut 12 and 18 inches, 20c per lb.

Bouquet Wire. Fine. 30c per lb.

Toothpicks. For stemming flowers, 10c per box.

Wax Paper. Per ream, 75c.

Bouquet Holders. Iron, for cemetery use, $30 \mathrm{c}$ each.

Bouquet Holders. Glass, for cemetery use, $35 \mathrm{c}$ each.

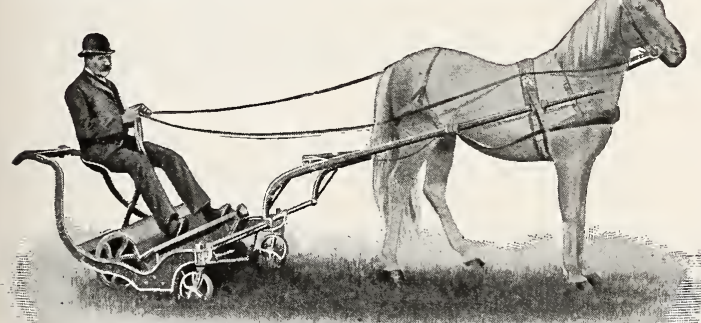

\section{Waterproof Flower Pot Saucers}

Indurated wood fibre; light, durable, not porous; protects tables on which plants stand. Each Doz. $\$ 0.17 \$ 1.90 \quad 10$ inch...............\$0.23 $\$ 2.70$

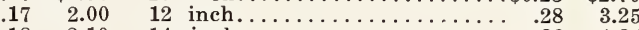

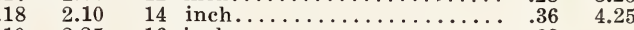

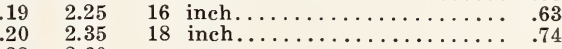

\section{The Links Lawn Boot}

For Use on Golf Links, Tennis Courts and Fine Lawns.

Aside from the lasting qualities it is the only humane boot, for the reason that it is firmly fastened to the hoof instead of around the ankle, thus giving free action to horse's feet and obviating all possibility of chafing. Price, set of four, $\$ 10.00$.

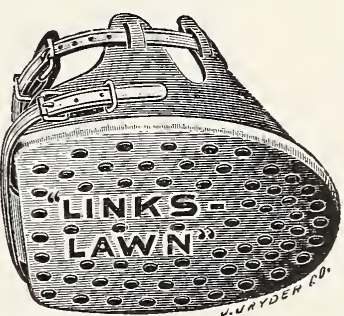

\section{Coldwell's Horse Lawn Mower}

Coldwell's Improved Horse Mowers are fitted up throughout with the best steel shafting, composition bushings or bearings, polished oak foot-boards, etc

Unquestionably the best Horse Lawn Mower manufactured, and guaranteed to give entire satisfaction.

30 -inch, with seat and shafts, $\$ 65.00$; 35 -inch, with seat and shafts, $\$ 75.00 ; 40$-inch, with seat and shafts, $\$ 90.00$. Furnished with side draft attachment which keeps the horse on the cut grass only.

\section{Townsend's Horse Lawn Mowers}

Triple rolls with triple pawls in each roll, making the most powerful and instantaneous driving mechanism ever put in a lawn mower. This feature maintains the motion of the blades even in turning sharp corners, and forms a strong contrast with other double roll mowers whose knives have no motion when turning corners. It is made very strong and powerful, of the very best materials, and finished in the most perfect manner.

It will cut over very rough and uneven ground and stand very rough usage, and still will get down into the turf and cut its swath clean, easily and smoothly. It is, on this account, very popular with golf clubs. We warrant it superior to any mower ever built, and will refund the purchase price to any customer dissatisfied after a trial.

Furnished with seat, handles and shaft complete and made 30 -inch or 38 -inch width of cut. Price, $\$ 60.00$ to $\$ 80.00$.

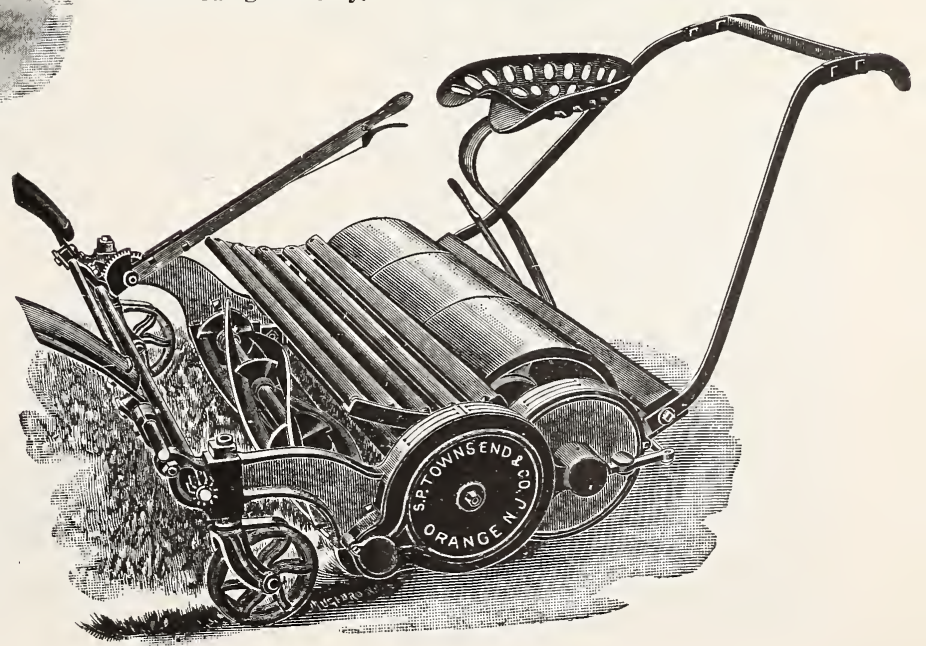




\section{“Lion” Ball Bearing Lawn Mower}

The ball bearing in lawn mowers is the latest and probably the greatest improvement in their manufacture. The "Lion" is constructed with 10 -inch skeleton rim driving wheels, $61 / 4$ inch cutting cylinder with five knives. Is a strong and powerful, easy running mower.

For those who mow their lawns frequently we advise the use of fine blade machines, as they leave the lawn in a very smooth condition.

16-inch, \$11.50 18-inch, \$12.50 20-inch, \$13.50.

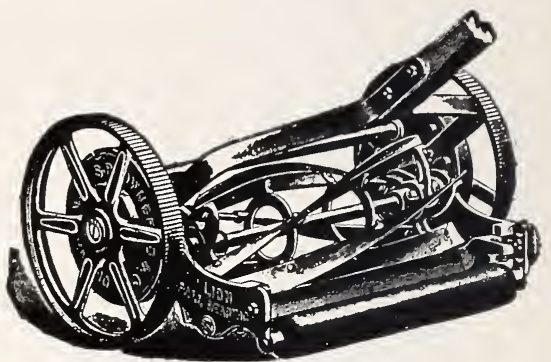

\section{Roller Lawn and Golf Mowers}

On lawns where exceptionally sine cutting is a necessity, there are no mowers equal to these. They cut smonthly, effectually doing away with that wavy appearance so often seen on a freshly cut lawn. They will also roll down a new lawn and protect it against upheavals caused by dampness, ants and other insects. These are the only mowers that will cut borders properly and without danger of cutting the sod.

Price, 18-inch, 6 blades, \$17.00.

\section{Derby Lawn Mower}

A Superior Medium Priced Machine

This mower is built to accommodate those who have only limited city lots to mow. And while of lighter construction than our "Lion," in quality of materials we consider it equal.

14-inch, \$7.00; 16-inch, \$8.00: 18-inch, \$9.00.

\section{Gleaner Lawn Trimmer}

Adapted to trimming edges of walks, drives, beds, etc., which cannot be reached with the regular mower, and have required tedious hand labor. 8-inch cut, $\$ 6.00$.

\section{"Iron Age" Combined Seed Drill and Double Wheel Hoe}

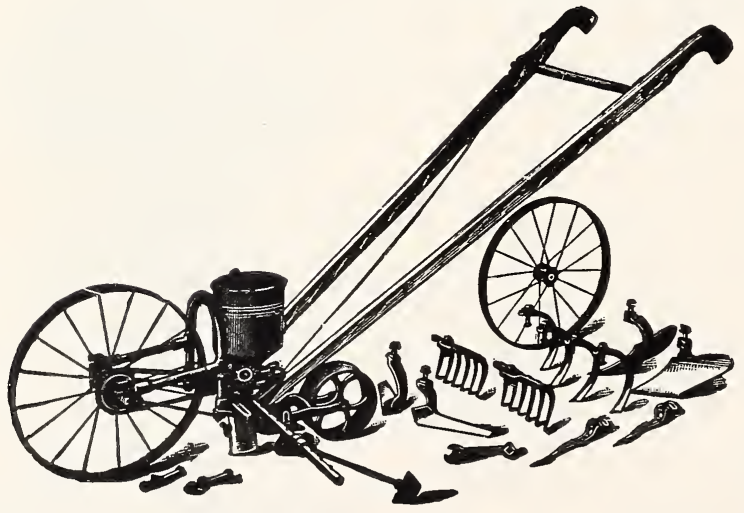

The Seed Drill is complete in itself, merely requiring to be bolted with two bolts to the wheel frame. As a drill it opens the furrow, drops the seed, covers and rolls it and marks the next row at one passage. It can be set to sow shallow or deep, thick or thin, as the flow of seed can be instantly shut off to turn rows. The agitator is a revolving brush which will not injure seed in the slightest.

Combined Irill Seeder and Double Wheel Hoe, \$13.75; combined Hill and Drill Seeder and Double Wheel Hoe, \$15.00. Hill and Drill Seeder without attachments. \$11.25; Double Wheel Hoe complete, \$8.75: Single Wheel Hoe complete. \$7.50.

\section{The "Gem of the Garden" Wheel Hoe}

Single Wheel Hoe.

No greater proof can be given of the popularity of a tool, or its intrinsic worth, than the one simple fact of a continued demand for it In the pat few years there have been placed about fifteen thousand of the "Gem" Wheel Hoes in the hands of gardeners, and we are not aware of a single instance in which it has failed to give entire satisfaction to the user It is not a toy, neither is it a tool made of light gray castings, calling for constant repair, the "Gem" being largely made up of steel and malleable iron. The set of slender, stirring teeth, each stamped from one piece of steel, cannot be excelled for thorough . work, especially in hard soil. Price, complete, \$6.25. With teeth only, $\$ 4.75$

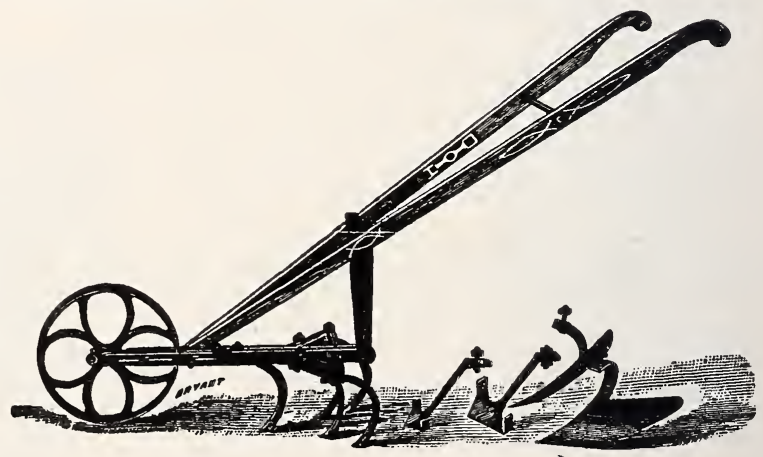




\section{N D E X}

\section{A}

Artichokes $\ldots \ldots \ldots \ldots \ldots .2$

Asparagus $\ldots \ldots \ldots \ldots \ldots 2$

B

Beans ............ 2 Beets ............

Begonias ..........23

Bird Seed ...........12

Borecole ...........

Broccoli ........... 3

Brussels Sprouts ........ 3

Bulbs .......23-24

\section{C}

Cabbage .......... 4

Caladium .............. 23

Calla Lilies ..........23

Cannas ............23

Carrots ............ 3

Cauliflower .......... 4

Celery ............. 4

Chard, Swiss ........ 3

Chervil ........... 4

Climbing Plants ......26

Clovers ............12

Corn $\ldots \ldots \ldots \ldots \ldots$.

Corn Salad ......... 5

Cress ............. 5

Cucumbers ........

D

Dahlias ...........23

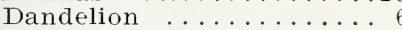

E

Egg Plant ........ 6

Endive $\ldots \ldots \ldots \ldots \ldots 6$

F

Fertilizers $\ldots \ldots \ldots \ldots 27$

Fetticus ..............
Flower Seeds $\ldots \ldots \ldots 13-22$

Fruits $\ldots \ldots \ldots \ldots 26$

\section{G}

Garden Implements...28-32 Gladiolus ...........24 Gloxinias ..........23 Grains, etc. .........12 Grasses, Ornamental ....22 Grass Seeds ............. 12

Gumbo ............ 7

\section{H}

Hedge Plants .........25 Herbs ............... Hyacinthus $\ldots \ldots \ldots \ldots 24$

I

Insecticides $\ldots \ldots \ldots \ldots 28$ Ismene ...........24

$\mathbf{K}$

Kale

Kohl Rabi

$\mathbf{L}$

Leek

Lettuce

Lilies

Madeira Vine

Mangel Wurzels ..........................

Millets .............12

Montbretias ..........24

Mushrooms ........ 7

Muskmelon $\ldots \ldots \ldots \ldots \ldots 7$

Mustard

$\mathbf{N}$
O

Okra

Onions

Oxalis

Oyster Plant

\section{$\mathbf{P}$}

Parsley

Parsnips

Peas

Pepper Grass

Peppers

Perennials

Potatoes

Poultry Supplies ...........27

Pumpkins

R

Radishes

Roses

$\mathbf{S}$

Salsify

Shrubs

Spinach

Spinach Beet

Squash

$\mathbf{T}$

Tigridias ..............

Tobacco ….............

Tomatoes ............11

Tools and Requisites...28-29

Tuberoses ...........24

Turnips ..............

V

Vegetable Roots

Vegetable Seeds ......2-11

Vines .....................

WV

\section{FARMOGERM HIGH BRED NITROGEN- GATHERING BACTERIA}

"Makes Poor Soil Good Soil"

It is well known that nitrogen is the most expensive of fertilizing elements. It is also known that it is the plant food in which most soils are deficient. We are pleased, therefore, to be able to offer our patrons an improved and most reliable method of inoculating soil with nitrogen-gathering bacteria. By moistening the seed of any leguminous crop to be planted with Farmogerm, not only is the immediate crop benefited by this pure culture of high bred nitrogengathering bacteria, but the soil is enriched in nitrogen which will be available for future crops of any kind for two or three seasons. One of the important advantages which Farmogerm has over other and earlier preparations of this kind is the fact that it needs no treatment or development before using. It comes in sealed bottles ready for use with a little water according to directions.

Soil inoculation is a big subject, and the possibilities of it are only partly appreciated by many. We have no space for details here but we hope our customers will write us for a free pamphlet on the subject, which we will be pleased to send. Investigate before planting any of the following crops:

Alfalfa, Alsike, Berseem, Crimson Clover, Red Clover, White Clover, Canadian Field Peas, Cow Peas, Soy Eeans, Velvet Beans, Vetch, Lupins, Peanuts, Garden Beans, Garden Peas, Sweet Peas and other legumes.

When ordering be sure and state for what crop Farmogerm is wanted.

We are prepared to supply Farmogerm for any one of all these crops at the laboratory price of $\$ 1.50$ per acre; five acre size, $\$ 5.00$.

Garden size, mixed culture, good for Peas, Beans, and Sweet Peas, $1 / 8$ acre, $25 \mathrm{c}$; $1 / 4$ acre, $50 \mathrm{c}$. Also White Clover for lawns.

The U. S. Department of Agriculture says: "The pure culture method has come to stay."

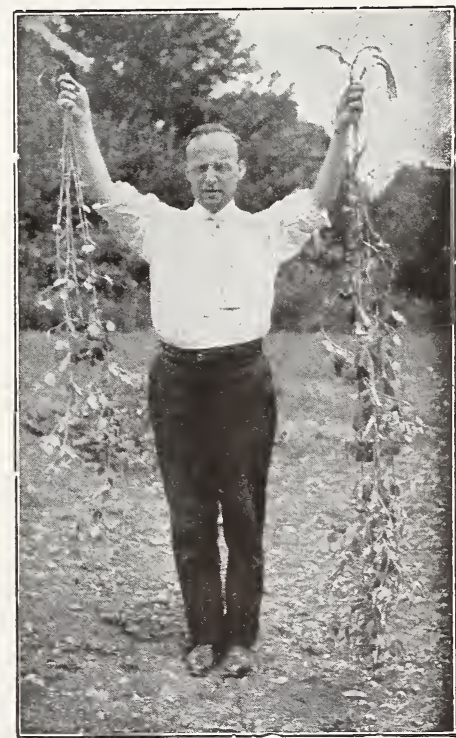




\section{WILLIS S. PINO, Seedsman}

RELIABLE SEEDS

FOR FARM AND GARDEN

Flowering Bulbs

Florists' Supplies

41 Washington St.,

Providence, R. I. 